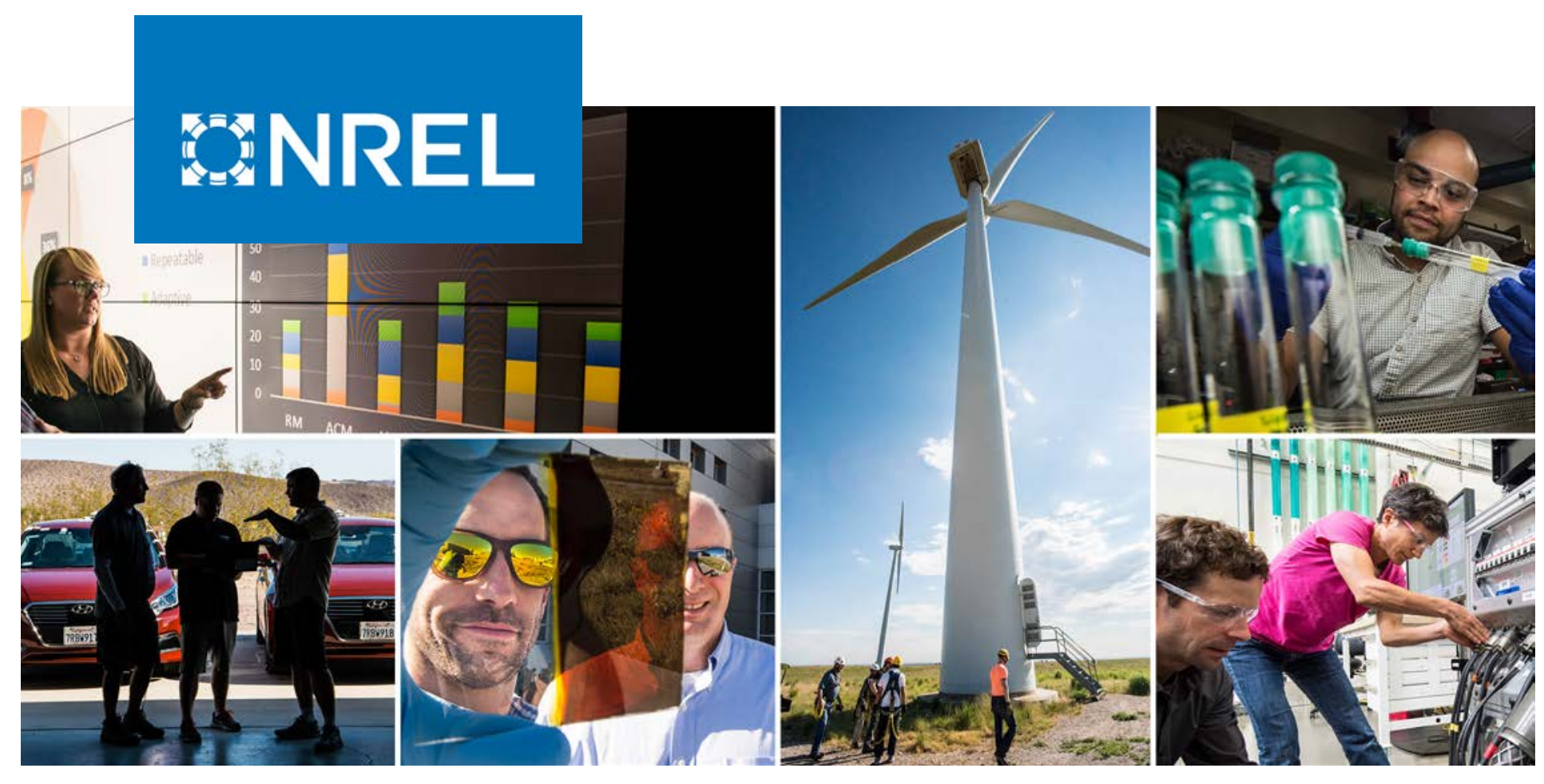

\title{
2017 Bioenergy Industry Status Report
}

Kristi Moriarty, Anelia Milbrandt, John Lewis, and Amy Schwab

National Renewable Energy Laboratory

NREL is a national laboratory of the U.S. Department of Energy

Office of Energy Efficiency \& Renewable Energy

Operated by the Alliance for Sustainable Energy, LLC

This report is available at no cost from the National Renewable Energy Laboratory (NREL) at www.nrel.gov/publications.

\section{Technical Report}

NREL/TP-5400-75776

February 2020 


\title{
GHREL
}

\section{Bioenergy Industry Status Report}

\author{
Kristi Moriarty, Anelia Milbrandt, John Lewis, \\ and Amy Schwab
}

National Renewable Energy Laboratory

\section{Suggested Citation}

Moriarty, Kristi, Anelia Milbrandt, John Lewis, and Amy Schwab. 2020.

2017 Bioenergy Industry Status Report. Golden, CO: National Renewable Energy

Laboratory. NREL/TP-5400-75776. https://www.nrel.gov/docs/fy20osti/75776.pdf.

NREL is a national laboratory of the U.S. Department of Energy Office of Energy Efficiency \& Renewable Energy Operated by the Alliance for Sustainable Energy, LLC

This report is available at no cost from the National Renewable Energy Laboratory (NREL) at www.nrel.gov/publications.

Contract No. DE-AC36-08GO28308
Technical Report NREL/TP-5400-75776

February 2020

National Renewable Energy Laboratory 15013 Denver West Parkway Golden, CO 80401 303-275-3000 • www.nrel.gov 


\section{NOTICE}

This work was authored by the National Renewable Energy Laboratory, operated by Alliance for Sustainable Energy, LLC, for the U.S. Department of Energy (DOE) under Contract No. DE-AC36-08GO28308. Funding provided by U.S. Department of Energy Office of Energy Efficiency and Renewable Energy Bioenergy Technologies Office. The views expressed herein do not necessarily represent the views of the DOE or the U.S. Government.

This report is available at no cost from the National Renewable Energy Laboratory (NREL) at www.nrel.gov/publications.

U.S. Department of Energy (DOE) reports produced after 1991 and a growing number of pre-1991 documents are available free via www.OSTI.gov.

Cover Photos by Dennis Schroeder: (clockwise, left to right) NREL 51934, NREL 45897, NREL 42160, NREL 45891, NREL 48097, NREL 46526.

NREL prints on paper that contains recycled content. 


\section{Preface}

This report provides a snapshot of the bioenergy industry status at the end of 2017. The report complements other annual market reports from the U.S. Department of Energy's (DOE's) Office of Energy Efficiency and Renewable Energy and is supported by DOE's Bioenergy Technologies Office (BETO). The 2017 Bioenergy Industry Status Report focuses on past year data covering multiple dimensions of the bioenergy industry and does not attempt to make future market projections. The report provides a balanced and unbiased assessment of the industry and associated markets. It is openly available to the public and is intended to complement International Energy Agency and industry reports with a focus on DOE stakeholder needs.

The bioenergy economy engages multiple industrial sectors across the biomass-to-bioenergy supply chain - from agricultural- and forestry-based industries that produce biomass materials, to manufacturers and distributors of biomass-based fuels, products, and power, to the ultimate enduser markets. The breadth of this report focuses on activities that occur after the production of biomass. The report compiles and integrates information to provide the bioenergy industry status at the end of 2017 and includes 10 years of past data to show trends over time. It also highlights some of the key energy and existing regulatory drivers that have impacted the bioenergy industry as it develops. The information is intended for technology developers, policymakers, and other bioenergy stakeholders interested in bioenergy industry development.

The report begins with a discussion of the overall size and composition of the domestic bioenergy market and follows with sections on biofuels, biopower, and bioproducts. The biofuels section is broken out by fuel type with detailed sections on ethanol (conventional and cellulosic), biodiesel, and hydrocarbon fuels (gasoline, diesel, and jet fuel), as well as summary information and data on biobutanol and renewable natural gas. The report also offers an overview of bioproducts that have the potential to enable bioenergy production.

In total, the information contained in this report is intended to communicate an understanding of the U.S. bioenergy industry status. On behalf of DOE and BETO, I hope that you explore and find value in this report.

Sincerely, Jonathan L. Male

Director, Bioenergy Technologies Office

Office of Energy Efficiency and Renewable Energy

U.S. Department of Energy 


\section{Acknowledgments}

Funding for this report came from the U.S. Department of Energy's Office of Energy Efficiency and Renewable Energy's Bioenergy Technologies Office. The authors appreciate input from the Environmental Protection Agency and Mary Biddy and Chris Kinchin from the National Renewable Energy Laboratory. 


\section{List of Acronyms}

$\mathrm{AD}$ anaerobic digestion

ADM Archer Daniels Midland

$\mathrm{A} / \mathrm{E} \quad$ acid/enzymatic

AFDC Alternative Fuels Data Center

ASTM ASTM International

ATJ

B5

B20

B100

BETO Bioenergy Technologies Office

Btu

CAFE

British thermal unit

$\begin{array}{ll}\text { CAFE } & \begin{array}{l}\text { Corporate Average Fuel } \\ \text { Economy }\end{array} \\ \text { CHP } & \begin{array}{l}\text { combined heat and power } \\ \text { DOE }\end{array} \\ \text { E10 } & \begin{array}{l}\text { U.S. Department of Energy } \\ \text { blend }\end{array}\end{array}$

E15 10.5\%-15\% ethanol and gasoline blend (approved for use in MY 2001 and newer vehicles)

E85 high ethanol blend between $51 \%$ and $83 \%$ ethanol, depending on season and geography

E100 neat ethanol

EIA U.S. Energy Information Administration

EISA Energy Independence and Security Act of 2007

EPA U.S. Environmental Protection Agency

FFV flexible-fuel vehicle
FT Fischer-Tropsch

gge gasoline gallon equivalent

GHG greenhouse gas

HEFA hydrogenated esters and fatty acids

kWh kilowatt-hour

LCOE levelized cost of electricity

LFG landfill gas

MFSP minimum fuel selling price

MMGY million gallons per year

MSW municipal solid waste

MTBE methyl tertiary-butyl ether

MW megawatt

MY model year

NORA National Oilheat Research Alliance

NREL National Renewable Energy Laboratory

RFS Renewable Fuel Standard

RIN Renewable Identification Number

RNG renewable natural gas

RVO renewable volume obligation

SIP synthetic isoparaffin

SKA synthetic kerosene with aromatics

SPK synthetic paraffinic kerosene

syngas synthesis gas

TBtu trillion British thermal units

ton short ton

USDA U.S. Department of Agriculture

VEETC Volumetric Ethanol Excise Tax Credit 


\section{Executive Summary}

The 2017 Bioenergy Industry Status Report compiles and integrates information to provide a snapshot of the current state and historical trends influencing the development of bioenergy markets as of the end of 2017. The information is intended for technology developers, policymakers, and other bioenergy stakeholders interested in bioenergy industry development. The bioenergy economy engages multiple industrial sectors across the biomass-to-bioenergy supply chain - from agricultural- and forestry-based industries that produce biomass materials, to manufacturers and distributors of biomass-based fuels, products, and power, to the ultimate enduser markets. It also highlights some of the key energy and existing regulatory drivers that have impacted the bioenergy industry as it develops. The breadth of this report focuses on activities that occur after the production of biomass.

At the end of 2017, the U.S. bioenergy market (shown in Figure ES-1) was dominated by conventional starch ethanol production, which accounts for $73 \%$ of total U.S. bioenergy production. Biodiesel and biopower make up nearly all the remaining production, while other advanced biofuels contribute a relatively small but increasing amount. ${ }^{1}$ Biofuels make up the largest portion (approximately 88\%) of the current bioenergy market.

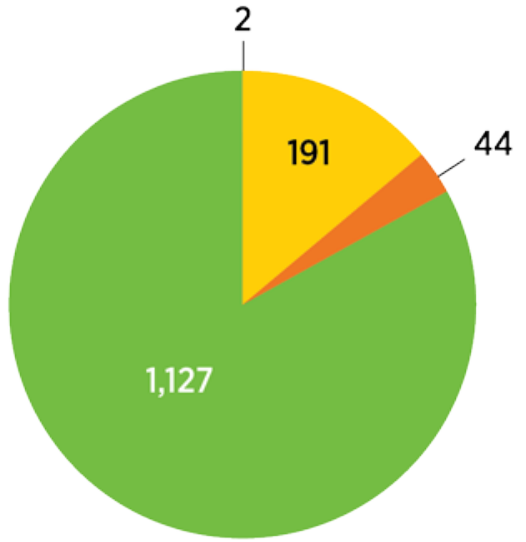

TBtu in 2010

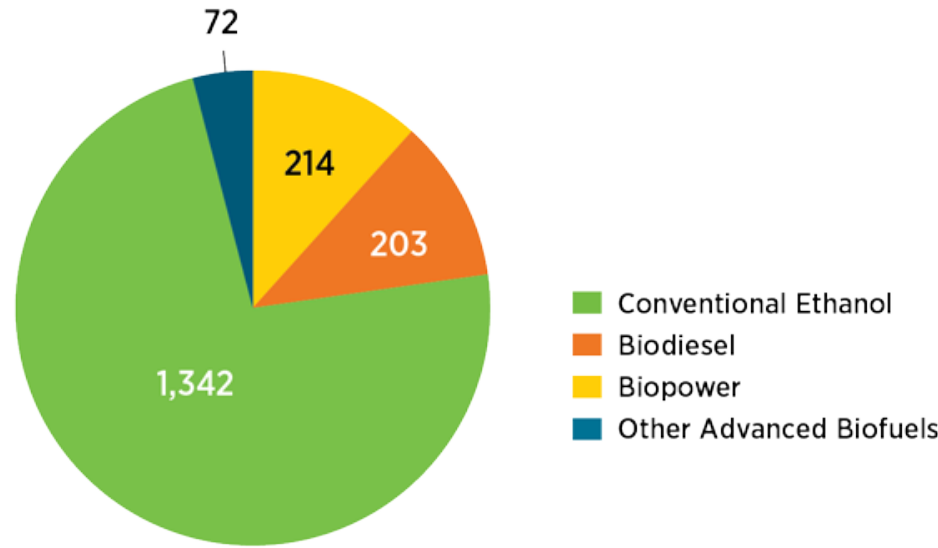

TBtu in 2017

Figure ES-1. U.S. bioenergy market (1,364 trillion British thermal units [TBtu] ${ }^{2}$ total in 2010 and 1,831 TBtu total in 2017)

Sources: Conventional Ethanol and Biodiesel: EIA 2018a, Tables 10.3 and 10.4; Biopower: EIA 2018b; Other Advanced Biofuels: EPA 2018a. Advanced biofuels include biobutanol, cellulosic fuels, heating oil, jet fuel, naphtha, renewable natural gas, and renewable diesel, as well as imports used to meet federal requirements for advanced biofuels. Note: This figure only includes the volume and electricity produced, and not the associated coproducts.

\footnotetext{
${ }^{1}$ Data for other advanced biofuels were obtained from the U.S. Environmental Protection Agency's (EPA's) Renewable Fuel Standard (RFS) data and based on volume generation. Other advanced biofuels include biogas, cellulosic ethanol, ethanol from other advanced feedstocks (including imported sugarcane ethanol), naphtha, renewable diesel, renewable gasoline, renewable heating oil, and renewable natural and liquefied gas. This data set includes small volumes of imported biofuels.

${ }^{2}$ One trillion British thermal units is equivalent to 0.001 quads.
} 
Figure ES-2 shows the development of the biofuels industry from 2008 through 2017. Policy combined with favorable market conditions during this time led to growth in the number and capacity of biofuels plants, as well as production. The build-out of starch-based ethanol plants and production was significant between 2006 and 2011, but since then, production has not grown as rapidly due to the E10 (a blend of 10 volume percent ethanol and $90 \%$ gasoline) blend wall. Driven by advanced biofuels requirements under the Renewable Fuel Standard (RFS) (EPA 2017), biodiesel production grew between 2011 and 2017. Advanced biofuels-which encompass a wide variety of fuels meeting RFS requirements for feedstocks, conversion pathways, and at least a 50\% reduction in greenhouse gas emissions - continue to make increases in market penetration, accounting for approximately 4\% of the bioenergy market in 2017.

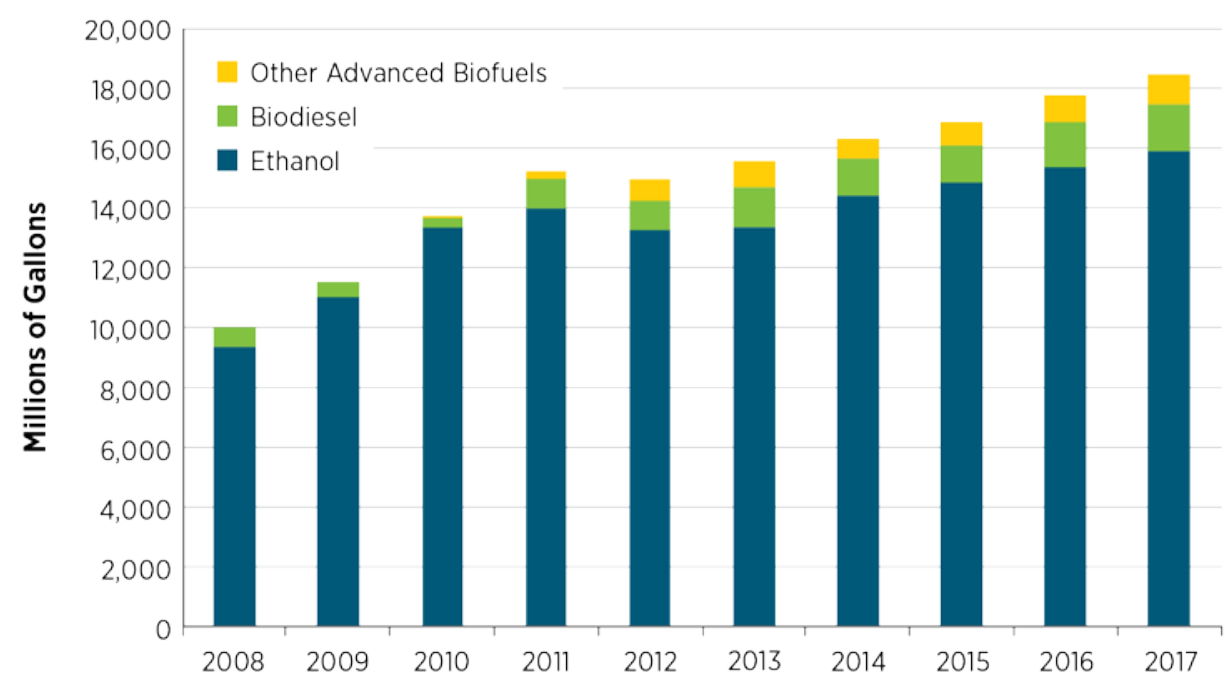

Figure ES-2. U.S. renewable fuels markets

Sources: Ethanol and Biodiesel: EIA 2018a, Tables 10.3 and 10.4; Other Advanced Biofuels: EPA 2018a ${ }^{3}$

Ethanol serves as a substitute for gasoline and as an octane enhancer. At the end of 2017, nearly all commercial ethanol biofuel production was from conventional cornstarch-based feedstock. The cost of conventional ethanol is driven by the price of corn grain, production costs, and the sale of coproducts such as distillers grains, and it is influenced by gasoline prices. At current levels of use, the nation is essentially at a blend wall - where the entire market for E10 is met with conventional ethanol. While there are nearly 20 million flexible-fuel vehicles on the road today that can use higher ethanol blends up to E85 (containing 51\% to 83\% ethanol, depending on geography and season), a majority of those vehicles are refueling with E10 gasoline.

Demand for ethanol could increase in future years because of the EPA's approval in 2011 of the use of E15 (a blend of $10.5 \%$ to $15 \%$ ethanol with gasoline) in existing vehicle model years 2001

\footnotetext{
${ }^{3}$ Data for advanced biofuels were obtained from the EPA's RFS data and were based on net supply. Other advanced biofuels include biogas, cellulosic ethanol, ethanol from other advanced feedstocks (including imported sugarcane ethanol), naphtha, renewable diesel, renewable gasoline, renewable heating oil, and renewable natural and liquefied gas. This data set includes small volumes of imported advanced biofuels.
} 
and newer. The availability of E15 increased in 2017 as retail stations installed E15 and/or E85 equipment with funding from the U.S. Department of Agriculture, states, and private industry.

Cellulosic ethanol production increased from 2.2 million gallons in 2015 to 10 million gallons in 2017 (EPA 2018a). The increase in production is due to corn ethanol plants adding technology to their existing plants to extract corn fiber (a cellulosic feedstock) to produce ethanol. To accommodate increased cellulosic ethanol, the domestic ethanol market would need to grow or exports would need to increase. The RFS requirement for cellulosic biofuels alone may not be enough to encourage investors given current market conditions, such as reduced oil prices and more fuel-efficient vehicles.

Economic impact analysis by industry estimates that ethanol's contribution to the U.S. gross domestic product increased from $\$ 17.7$ billion annually in 2005 to $\$ 45$ billion in 2017 (Urbanchuk 2018). The number of direct jobs has decreased, with 87,883 during the rapid buildout of plants in 2005 to 71,906 in $2017 .{ }^{4}$ The contribution of federal tax revenue from corn ethanol grew from \$1.9 billion in 2005 to \$5 billion in 2017.

Biodiesel production has generally increased during the past 10 years, primarily driven by two policies - the RFS and the biodiesel production tax credit. Economic impact analysis by industry estimates the biodiesel industry economic impact was $\$ 8.4$ billion and 47,400 direct jobs in 2015, the latest available data (NBB 2016).

Renewable hydrocarbon biofuels, sometimes referred to as "drop-in fuels," meet ASTM International fuel quality specifications for gasoline, diesel, and other petroleum fuels that allow them to be used in existing engines and infrastructure (AFDC 2018a). Renewable diesel is the most commonly used fuel in this category with over 602 million gallons reported under the RFS in 2017. Renewable jet fuel contributed to the RFS advanced biofuel category for the first time in 2016 with nearly 2 million gallons produced in both 2016 and 2017. Renewable hydrocarbons are produced from biomass sources through a variety of biological, chemical, and thermal processes.

In 2017, biopower accounted for $10 \%$ of all renewable energy produced in the United States and about $1.5 \%$ of total electricity generation. While the installed biopower capacity has been increasing over the past 10 years, biopower generation has remained almost flat during that period. In 2017, the top five states with the largest biopower generation were California, Florida, Georgia, Virginia, and Maine. Today, most of the biopower is generated from woody biomass, including byproducts (e.g., black liquor), solids (e.g., railroad ties and utility poles), and residues, such as those from pulp and paper mills or sawmills (EIA 2018c). Economic impact analysis estimates that a 50-megawatt (MW) dedicated biomass power plant utilizing direct combustion and using corn stover as feedstock could support about 25 direct on-site jobs during its operation (NREL 2014). A typical 3-MW landfill gas electricity project can directly create 5 jobs and indirectly create another 20 to 26 jobs during the construction year (Pierson 2013). Over their

\footnotetext{
4 The jobs estimated in Urbanchuk (2018) and NBB (2016) are different than job estimates in DOE's 2017 U.S.

Energy and Employment Report; the latter relied on surveys that can result in lower numbers.
} 
life, landfill gas projects are expected to add more than $\$ 1.5$ million in new project expenditures and increase the statewide economic output by $\$ 4.1$ million (Pierson 2013).

Renewable natural gas (RNG), or biomethane, is a pipeline-quality gas that is interchangeable with conventional natural gas and thus can be used in natural gas vehicles in compressed or liquefied form. RNG qualifies as a cellulosic biofuel under the RFS and is currently the main contributor to this fuel category (cellulosic ethanol provides a minor input). In 2017, EPA reports that about 239 million ethanol gallon equivalents, or roughly $18.2 \mathrm{TBtu}$ of compressed and liquefied RNG, were produced (EPA 2018a). This volume accounts for only $4.3 \%$ of the estimated RNG potential in the United States (NREL 2013).

Conventional bioproducts and emerging bioproducts are two broad categories used to classify products produced from biomass feedstocks. Examples of conventional bioproducts include building materials, pulp and paper, and forest products. Examples of emerging bioproducts include bioadhesives, biopolymers, and biochemicals. Emerging bioproducts are active subjects of research and development, and these development efforts have been driven by the price of traditionally petroleum-based products, the environmental impact of petroleum use, and an interest in becoming more independent from foreign oil. Bioproducts derived from bioresources can replace (either directly or indirectly) some of the fuels, chemicals, plastics, etc., that are currently derived from petroleum. Bioproducts can enable the production of bioenergy, either as coproducts to improve the economics of the primary fuel product in an integrated biorefinery, or as enablers in developing technologies and processes essential to the long-term production of biofuels and bioenergy. This report considers four types of bioproducts: (1) platform and intermediate chemicals (emerging bioproducts), as well as the conventional bioproducts; (2) lignin; (3) biochar; and (4) wood pellets. 


\section{Table of Contents}

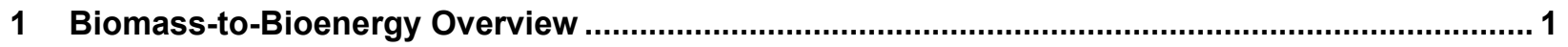

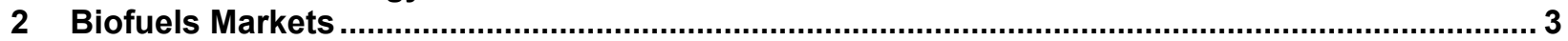

2.1 Ethanol 6

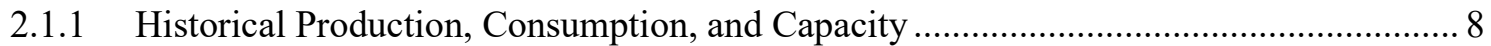

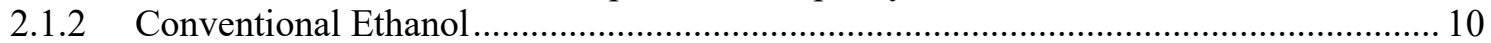

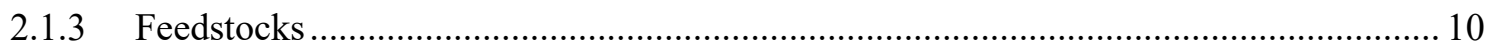

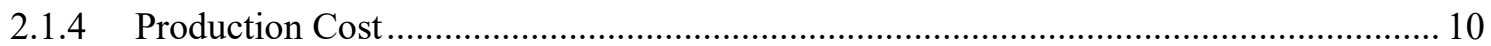

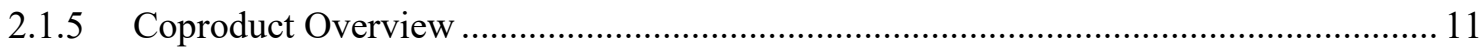

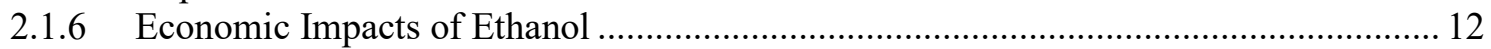

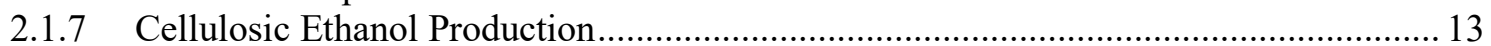

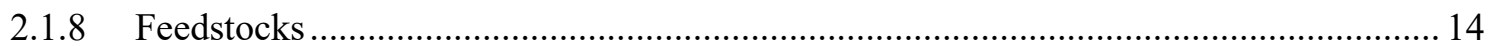

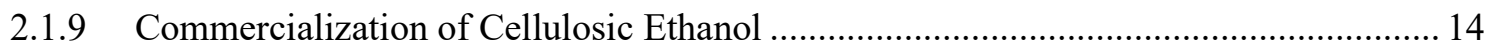

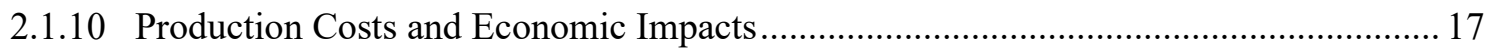

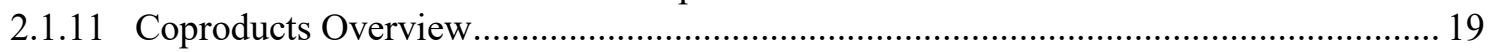

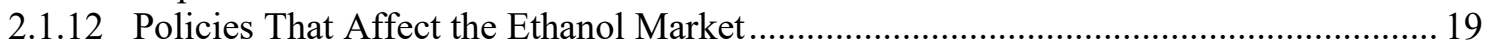

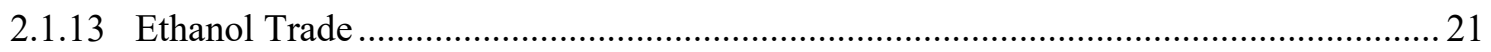

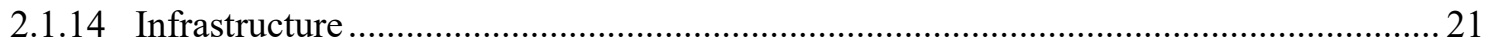

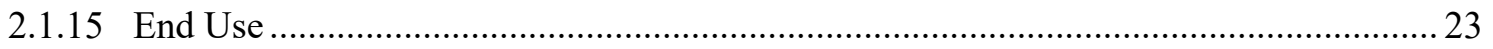

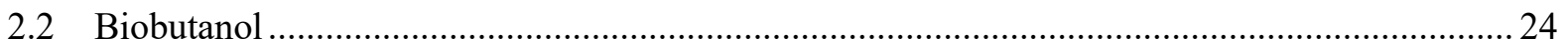

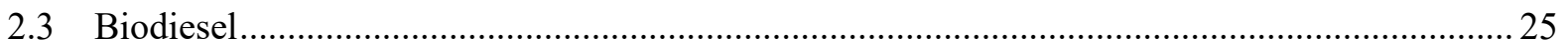

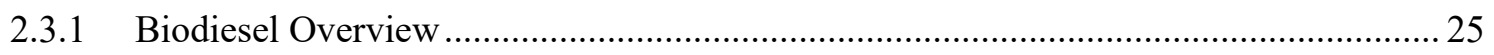

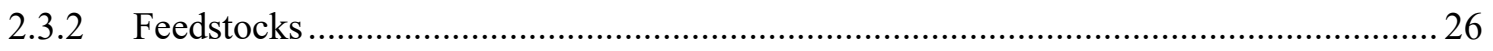

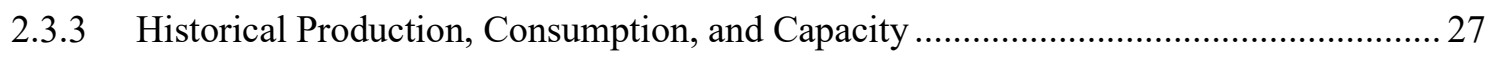

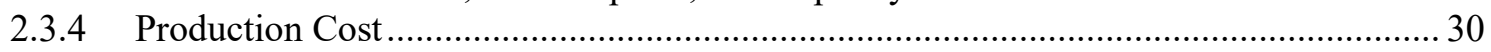

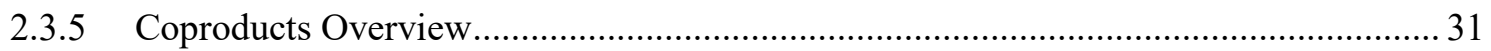

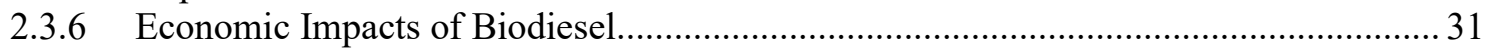

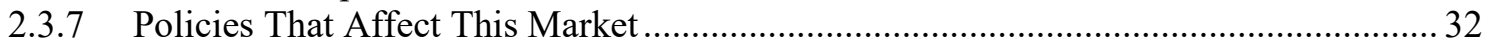

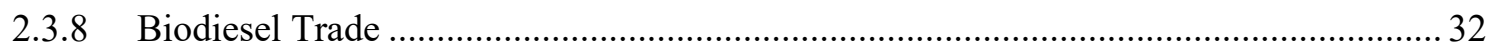

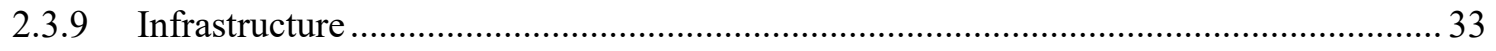

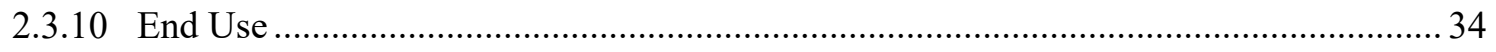

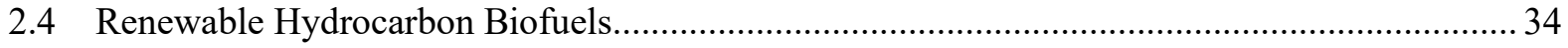

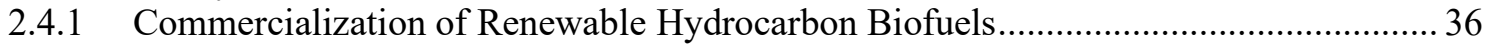

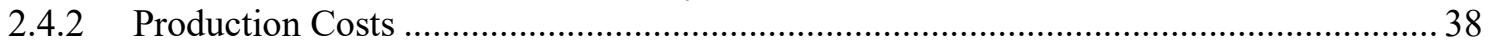

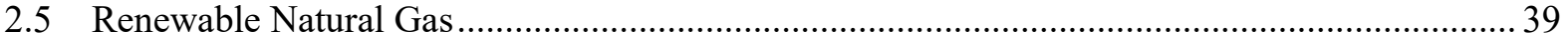

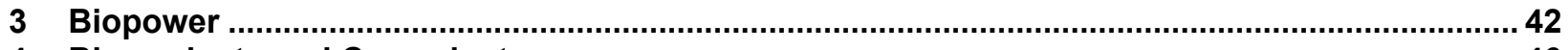

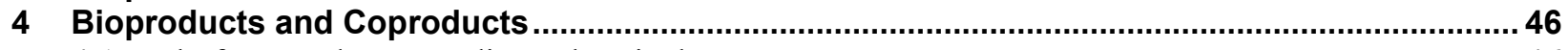

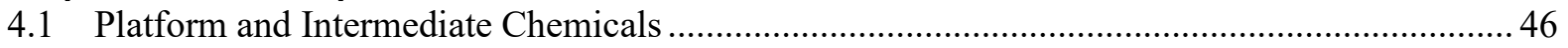

4.2 Lignin 48

4.3 Biochar 48

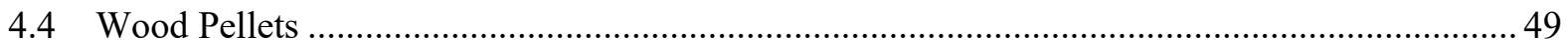

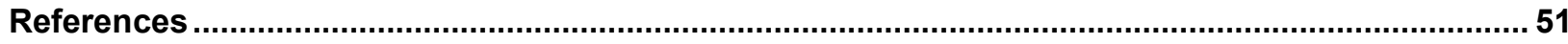

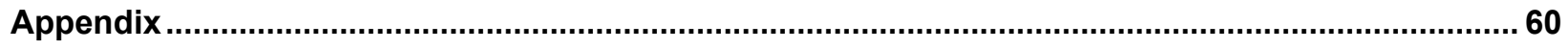




\section{List of Figures}

Figure ES-1. U.S. bioenergy market (1,364 trillion British thermal units [TBtu] total in 2010 and 1,831

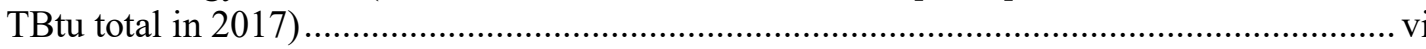

Figure ES-2. U.S. renewable fuels markets ............................................................................... vii

Figure 1. U.S. bioenergy market (1,364 TBtu total in 2010 and 1,831 TBtu total in 2017) ...................... 2

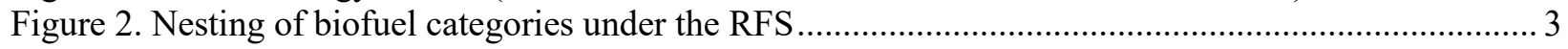

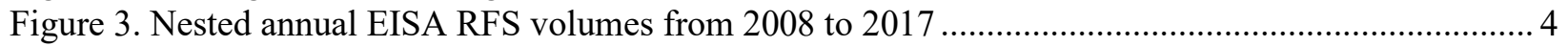

Figure 4. RFS comparison of EISA, annual RVO requirements, and RIN generation ............................. 5

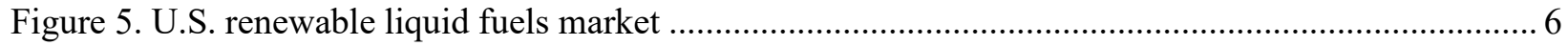

Figure 6. Historical corn, ethanol, and gasoline prices ....................................................................... 7

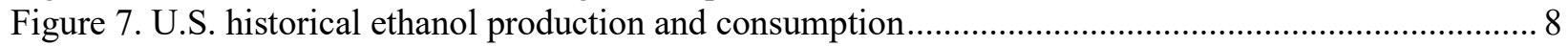

Figure 8. U.S. historical ethanol plants and capacity ........................................................................ 9

Figure 9. Ethanol plants by state (as of January 2018) ....................................................................... 9

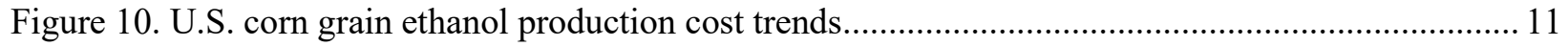

Figure 11. U.S. starch ethanol distillers grains production, trade, and price .......................................... 12

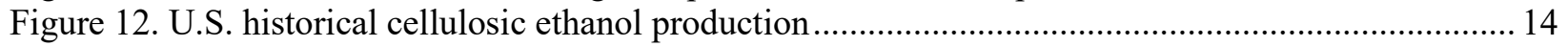

Figure 13. Biochemical cellulosic ethanol modeled production costs over time ..................................... 18

Figure 14. Thermochemical cellulosic ethanol modeled production costs over time .............................. 18

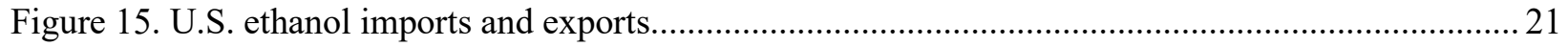

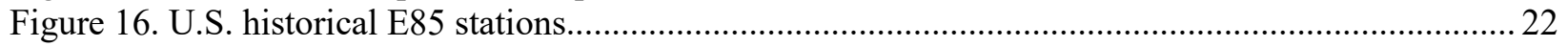

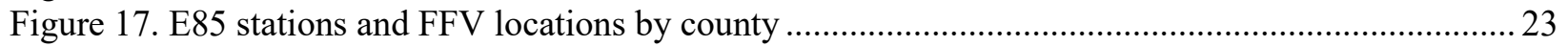

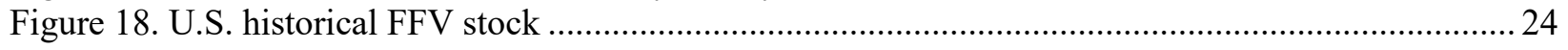

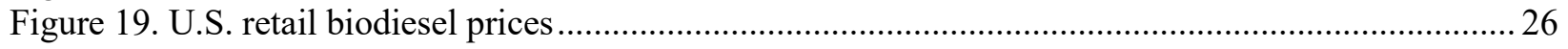

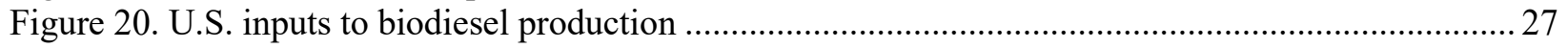

Figure 21. U.S. biodiesel production and consumption .................................................................. 28

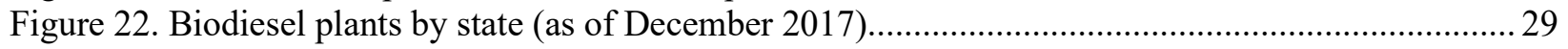

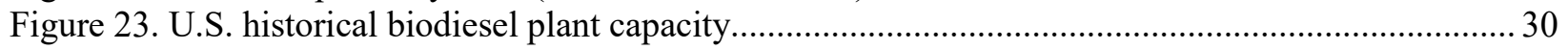

Figure 24. U.S. soybean-based biodiesel production cost trends .................................................... 31

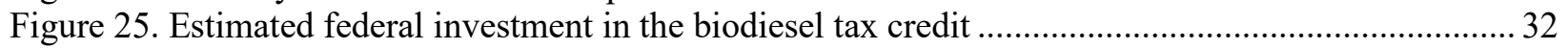

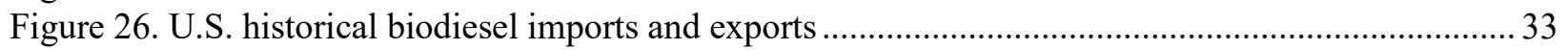

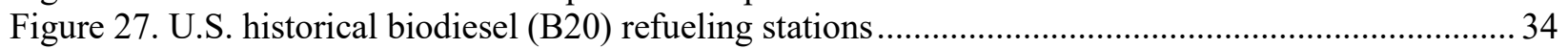

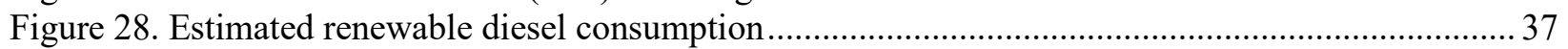

Figure 29. U.S. historical renewable gas production for transportation under the RFS ......................... 40

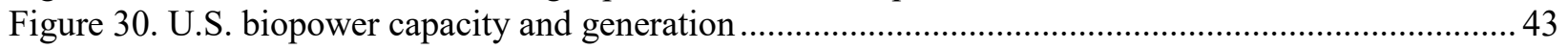

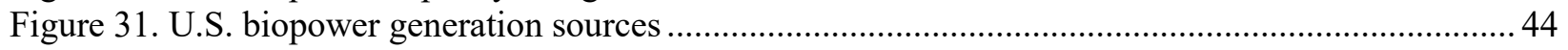

Figure 32. U.S. production (in million tons [MT]) and export value (\$/ton) of wood pellets in $2017 \ldots . . .50$

Figure 33. U.S. annual production and export of wood pellets............................................................ 50

\section{List of Tables}

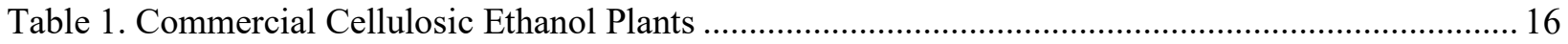

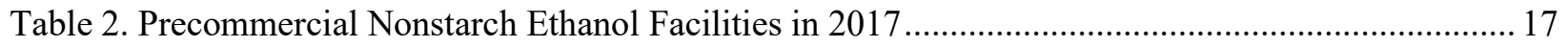

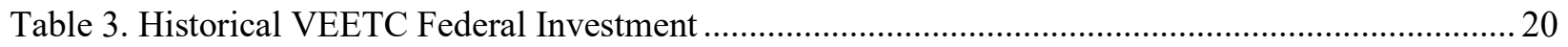

Table 4. Status of Commercial U.S. Renewable Hydrocarbon Projects in 2017 .................................... 37

Table 5. Status of Precommercial U.S. Renewable Hydrocarbon Projects................................................ 38

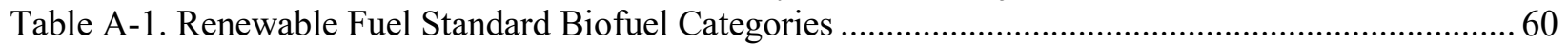

Table A-2. 2017 EPA Renewable Identification Number Generation.................................................... 61 


\section{Biomass-to-Bioenergy Overview}

Bioenergy — fuel, heat, and power derived from biomass sources — is an evolving market that produces and supplies renewable alternatives to fossil fuel sources. This report covers the following:

- Conventional ethanol - ethanol produced from starch (typically corn grain)

- Cellulosic ethanol—ethanol produced from cellulosic biomass, such as agricultural residues and woody resources

- Biobutanol — an alcohol that can be used as a fuel or fuel additive, currently produced from starch sources

- Biodiesel - an alternative to diesel that is typically produced from lipids

- Renewable hydrocarbon biofuels - diesel, jet fuel, and gasoline replacements compatible with existing engines and infrastructure, produced from various sources, such as vegetable and waste oils as well as cellulosic or algal biomass

- Renewable natural gas (RNG) - pipeline-quality gas, derived from renewable organic sources, which is interchangeable with conventional natural gas

- Biopower - generation of electricity from biomass sources

- Bioproducts and coproducts - including bioproducts and coproducts that are produced in conjunction with biofuels, or that enable bioenergy production.

Production, distribution, and use of bioenergy involve activities across a broad supply chain. These activities include the production of raw biomass in fields or forests; harvest, collection, storage, and transportation of these materials; and preprocessing of the raw biomass materialssizing, drying, or other mechanical, thermal, or chemical treatment - to produce a feedstock that can be fed into biorefinery conversion processes or into biopower-generating facilities. Distribution and use include delivering the bioenergy to market as well as the technical capability for end use of these products. While the bioenergy market is global and well established in other parts of the world, only the U.S. market was investigated and documented for this report.

In 2017, U.S. bioenergy production surpassed 1,831 trillion British thermal units (TBtu) ${ }^{5}$ from ethanol, biodiesel, renewable hydrocarbons, and biopower (EIA 2018a; EPA 2018a). A comparison of the contributions of biofuels and biopower to bioenergy production in 2010 and 2017 is shown in Figure 1. The growth in the "other advanced biofuels" category is driven by renewable natural gas and renewable diesel. Conventional starch ethanol production accounts for $73 \%$ of total bioenergy production. At current levels of ethanol use, the United States is essentially at a blend wall — where the entire market for E10 (a blend of 10 volume percent ethanol and 90 volume percent gasoline) is met with conventional ethanol. The best opportunities for near-term market expansion are increasing the use of E15 (10.5\%-15\% ethanol and gasoline

\footnotetext{
${ }^{5}$ One TBtu is equivalent to 0.001 quads.
} 
blend) in 2001 and newer model year (MY) vehicles and increasing the use of E85 (containing $51 \%$ to $83 \%$ ethanol, depending on geography and season) in flexible-fuel vehicles (FFVs). ${ }^{6} \mathrm{~A}$ longer-term possibility to increase ethanol consumption is deployment of vehicles with engines optimized to use high-octane fuel (e.g., research octane number 100), which could accommodate ethanol blends of $25 \%$ or greater or other high-octane biofuels. Federal and industry research and incentives led to an expansion in the availability of E15 and E85 at retail stations in 2017. The Corporate Average Fuel Economy (CAFE) credits have been a primary motivator for auto manufacturers to make FFVs. However, the long-term future for E85 is unclear as upcoming policy changes require vehicle manufacturers to prove FFVs are using E85 to receive a credit in the CAFE regulation. This may result in manufacturers producing fewer or no FFVs in future years.

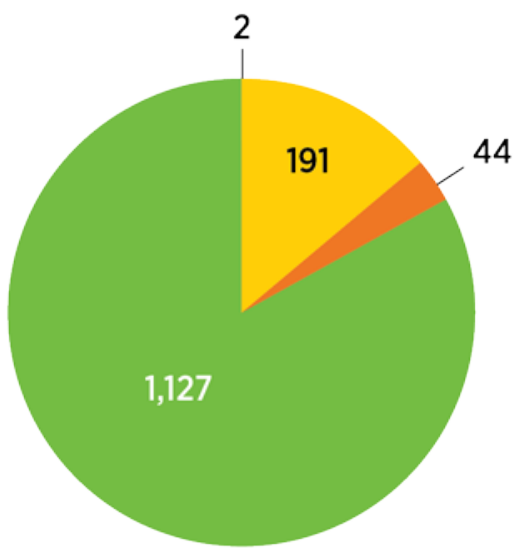

TBtu in 2010

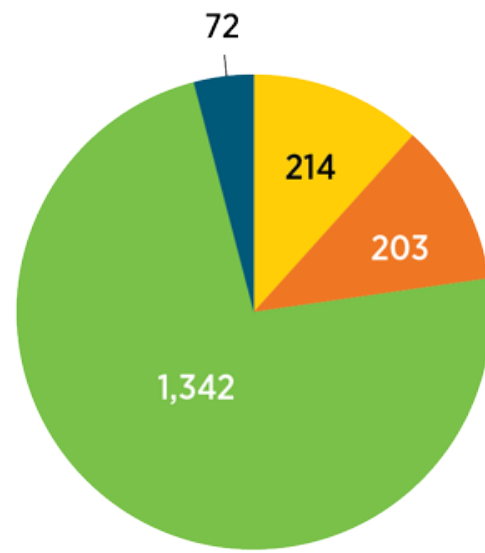

TBtu in 2017
Conventional Ethanol

Biodiesel

Biopower

Other Advanced Biofuels

Figure 1. U.S. bioenergy market (1,364 TBtu total in 2010 and 1,831 TBtu total in 2017)

Sources: Conventional Ethanol and Biodiesel: EIA 2018a, Tables 10.3 and 10.4; Biopower: EIA 2018b; Other Advanced Biofuels: EPA 2018a. Other advanced biofuels include biobutanol, biojet, cellulosic ethanol, ethanol from other advanced feedstocks (including imported sugarcane ethanol), naphtha, renewable diesel, renewable gasoline, renewable heating oil, and renewable natural and liquefied gas. Note: This figure only includes the energy content of the product fuels and power, and not the associated coproducts.

\footnotetext{
${ }^{6} \mathrm{E} 85$, also known as flex fuel, is a term that refers to high-level gasoline-ethanol blends containing $51 \%-83 \%$ ethanol, depending on geography and season.
} 


\section{Biofuels Markets}

A primary market driver for U.S. biofuels production and consumption is the Renewable Fuel Standard (RFS). The RFS is a federal program that requires transportation fuel sold in the United States to contain a minimum volume of renewable fuel. Congress created the RFS program to reduce reliance on imported oil and expand the nation's renewable fuels sector while reducing greenhouse gas (GHG) emissions (EPA 2018b). The RFS originated with the Energy Policy Act of 2005 and expanded under the Energy Independence and Security Act of 2007 (EISA) (U.S. Congress 2007).

The RFS program requires renewable fuel to be blended into transportation fuel in increasing amounts each year, escalating to 36 billion gallons by $2022 .^{7}$ The U.S. Environmental Protection Agency (EPA) manages and tracks RFS compliance through Renewable Identification Numbers (RINs). There are four overall RFS nested categories (Figure 2 and Figure 3): (1) renewable fuel, which is largely satisfied by conventional corn grain ethanol; (2) advanced biofuel; (3) biomassbased diesel, which is largely satisfied by biodiesel; and (4) cellulosic biofuel. Figure 2 illustrates how RIN designations allow fuels to meet more than one RFS category. For example, cellulosic diesel represents the overlap between cellulosic biofuel and biomass-based diesel. There is no specific requirement for starch-based ethanol, although this fuel accounts for the majority of fuel in meeting the RFS - it falls under the overall requirement of renewable fuel. The RFS program requires renewable fuels to emit lower levels of GHGs than the petroleum fuel they replace. Specific GHG emission reductions are $20 \%$ for renewable fuel (conventional ethanol); $50 \%$ for advanced biofuel and biomass-based diesel; and $60 \%$ for cellulosic biofuels. ${ }^{8}$ In the Appendix, Table A-1 includes more detailed definitions for the RFS biofuel categories.

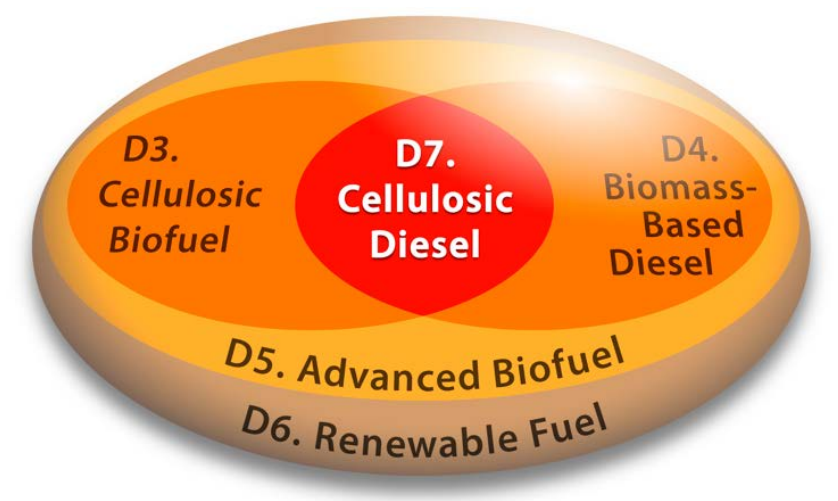

Figure 2. Nesting of biofuel categories under the RFS

See Appendix for definitions for each biofuel category. Cellulosic biofuel (D3) and biomass-based diesel (D4) are both nested within advanced biofuel (D5), which is nested within renewable fuel (D6). Note: Diagram not to scale.

\footnotetext{
${ }^{7}$ RFS gallons are ethanol-equivalent gallons, except for biodiesel, which is actual gallons.

${ }^{8}$ Facilities that existed or commenced construction prior to December 19, 2007, are exempt from the $20 \%$ lifecycle GHG-emission reduction threshold requirement; ethanol plants that began construction prior to January 1, 2010 and use natural gas or biomass for thermal energy are also exempt.
} 


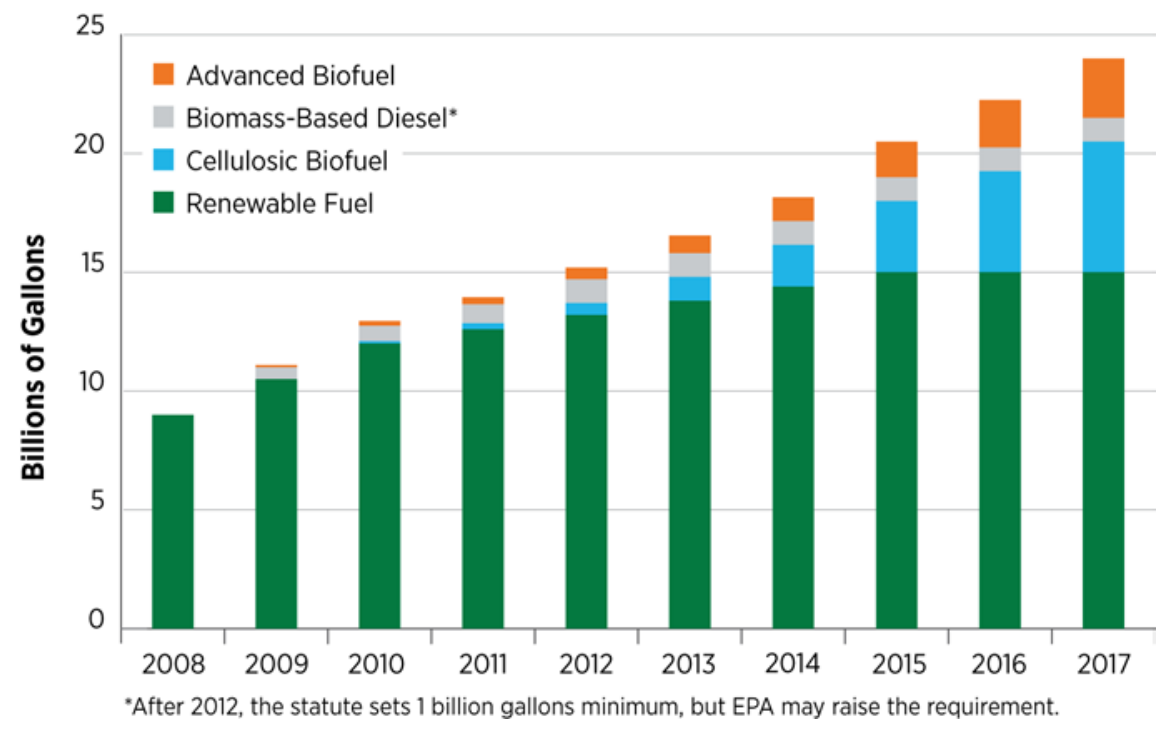

Figure 3. Nested annual EISA RFS volumes from 2008 to 2017

Source: U.S. Congress 2007

To meet the fuel blend requirements, the RFS program assigns obligated parties (fuel refiners and importers) a renewable volume obligation (RVO), which is the volume of renewable fuels the party is required to blend based on a percentage of the company's total fuel sales.

RINs are the mechanism for tracking annual renewable fuel blend requirements across the various biofuel categories. In the Appendix, Table A-2 includes data on RIN generation in 2017 (EPA 2018a). RINs are generated when designated biofuels are imported or are produced and conveyed with the volumetric sale of those biofuels until blended with petroleum products or sold to an obligated party. Once the fuel is blended, the RIN can be used to demonstrate a company's RVO compliance to EPA and then is retired. RINs also may be sold or saved for meeting RVO requirements in the next compliance year. Most RIN prices are determined by market factors typical of other commodities, while EPA can impact the cellulosic biofuel RIN price through offering cellulosic biofuel waiver credits.

Figure 4 compares EISA-legislated volumes, EPA annual RVO volumes (published and adjusted each year based on demand), and RINs retired. Fuel producers have mostly met EPA annual RVOs every year, but the RVO amount was less than the legislated volumes that were adjusted down in 2014 through 2017 due to limited cellulosic biofuel production. 


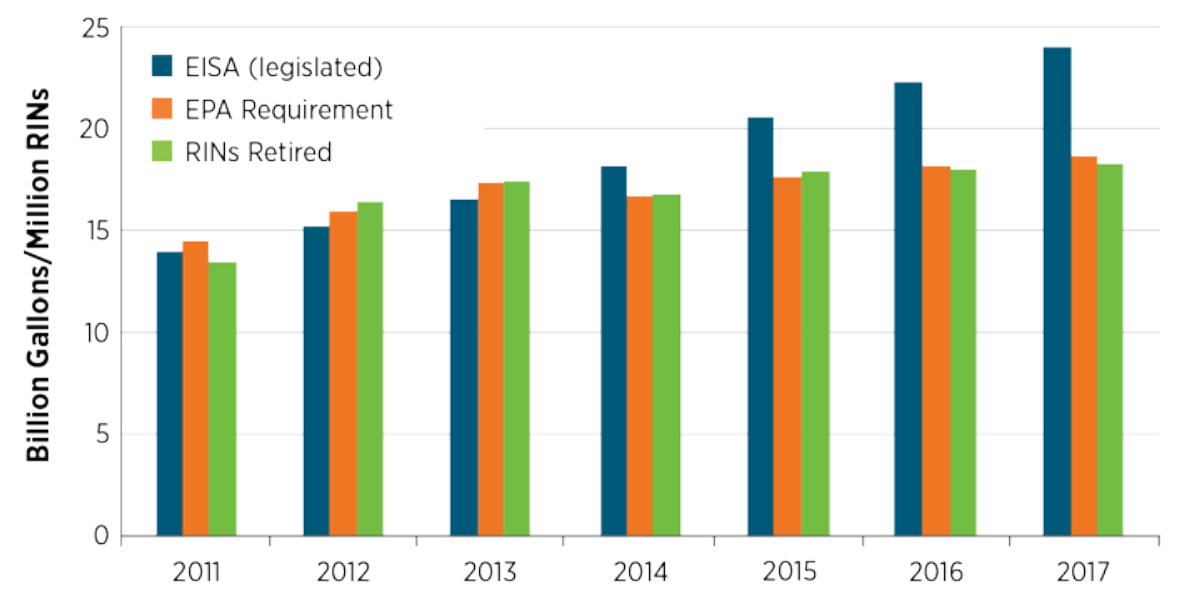

Figure 4. RFS comparison of EISA, annual RVO requirements, and RIN generation

Sources: U.S. Congress 2007; EPA 2018a

Figure 5 shows data for conventional ethanol, biodiesel, and other advanced biofuels (including net supply of biobutanol, biojet, cellulosic ethanol, ethanol from other advanced feedstocks [including imported sugarcane ethanol], naphtha, renewable diesel, renewable gasoline, renewable heating oil, and renewable natural and liquefied gas). The biofuels market is dominated by conventional starch-based ethanol. Biodiesel production increased from 1.57 billion gallons in 2016 to 1.59 billion gallons in 2017 while consumption declined slightly from 2.09 billion gallons in 2016 to 1.96 billion gallons in 2017 (EIA 2018a). Production and consumption of renewable diesel and RNG (which accounts for the majority of the cellulosic biofuel) have grown significantly. Renewable diesel and RNG RFS volumes reported in 2017 were 558 million gallons and 241 million gallons, respectively (EPA 2018a). ${ }^{9}$ Cellulosic ethanol production grew from 0.7 million gallons in 2014 to more than 10 million gallons in 2017 (EPA 2018a).

\footnotetext{
${ }^{9}$ Renewable diesel RINs are multiplied by 1.7 for ethanol equivalence. Actual net supply of renewable diesel reported in 2017 was 558 million gallons.
} 


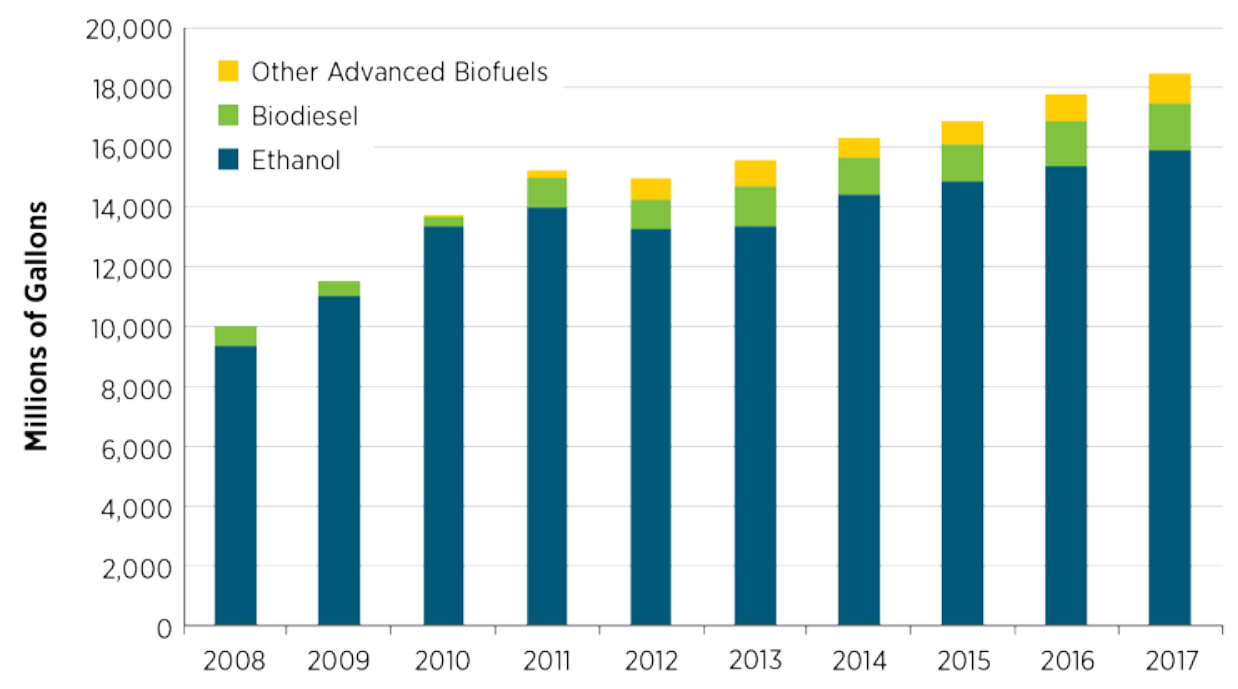

Figure 5. U.S. renewable liquid fuels market

Sources: Ethanol and Biodiesel: EIA 2018a, Tables 10.3, 10.4; Other Advanced Biofuels: EPA 2018a ${ }^{10}$

\subsection{Ethanol}

Ethanol is a widely used biofuel made from corn grain and other plant materials. In 2017, 95.8\% of domestic ethanol production was from corn grain (RFA 2018a). Ethanol has a long history of use in the United States dating back to the introduction of motor vehicles. It became more common as an oxygenate additive and octane enhancer in gasoline after passage of major amendments to the Clean Air Act in 1990 that required oxygenates to be used in reformulated gasoline. Another oxygenate, methyl tertiary-butyl ether (MTBE), was the primary product used to meet the standard until it was found to contaminate ground water, and some states banned its use or proposed banning its use. Ethanol was voluntarily used to replace MTBE in these areas, and production and consumption increased dramatically. Today, ethanol consumption is driven by both the RFS and octane requirements. Pipelines ship a variety of gasoline and gasoline blendstocks to meet demand, which varies regionally. Many of these products are sub-octane, meaning they have a lower octane than is required for sale to consumers at a station. Ethanol has a higher octane number than gasoline, and refiners provide a gasoline blendstock that, when blended with ethanol, will meet octane specifications necessary for vehicle performance needs. Ethanol is delivered to terminals or blenders by rail car, tanker truck, or barges, and it is then blended with gasoline and delivered by truck to stations.

As a domestically produced biofuel, ethanol reduces reliance on imported petroleum products and provides jobs in rural areas. In $2005,60 \%$ of petroleum products were imported; however, that was reduced to less than $20 \%$ in 2017 because of increased domestic crude oil and ethanol production, as well as decreased gasoline consumption (RFA 2018b). Under the RFS, corn grain ethanol meets the renewable fuel $20 \%$ GHG-emission reduction threshold and is currently the

\footnotetext{
${ }^{10}$ Data for advanced biofuels were obtained from the EPA's RFS data and were based on net supply. Other advanced biofuels include biobutanol, biojet, cellulosic ethanol, ethanol from other advanced feedstocks (including imported sugarcane ethanol), naphtha, renewable diesel, renewable gasoline, renewable heating oil, and renewable natural and liquefied gas.
} 
main contributor to this fuel category (EPA 2010; EPA 2018a; EPA 2018b). Imported sugarcane ethanol meets the advanced biofuel 50\% GHG-emission reduction threshold (EPA 2010; EPA 2018a; EPA 2018b). Cellulosic ethanol meets the cellulosic biofuel 60\% GHG-emission reduction threshold and is currently a minor contributor to this fuel category (EPA 2010; EPA 2018a).

Nearly all (98\%) gasoline sold in the United States contains ethanol, and nearly all ethanol is sold as E10 (RFA 2018b). Another long-available blend is E85, which can be used in FFVs. At the end of 2017, E85 was available at more than 3,379 fueling stations, and more than 21 million FFVs were registered nationwide. In 2011, EPA approved E15 for use in MY 2001 and newer vehicles. The number of stations offering E15 grew from 180 in 20 states at the beginning of 2016 to more than 1,200 in 30 states at the end of 2017 (Growth Energy 2018). The U.S. Department of Agriculture's (USDA's) Biofuels Infrastructure Partnership funded ethanol infrastructure for E15 and E85 at approximately 880 retail fuel stations in 20 states through a cost-share program led by state coalitions that matched USDA funds (USDA 2015). In addition, industry is also helping fund stations for equipment upgrades to offer E15 and/or E85.

The primary drivers of ethanol prices are the cost of corn grain and the gasoline prices for which ethanol serves as a substitute product. In the past 10 years, ethanol prices have fluctuated in correlation with gasoline or corn grain prices. When corn grain was relatively inexpensive and petroleum prices were increasing (from 2004 through 2010), ethanol futures traded based on gasoline prices. As ethanol began to consume a larger percentage of corn grain production, its price increasingly moved in sync with corn grain prices when domestic supply of corn was tight. More recently, as corn grain prices have dropped lower, ethanol prices have been based at a discount to gasoline prices. Figure 6 compares ethanol and gasoline futures prices with corn grain prices.

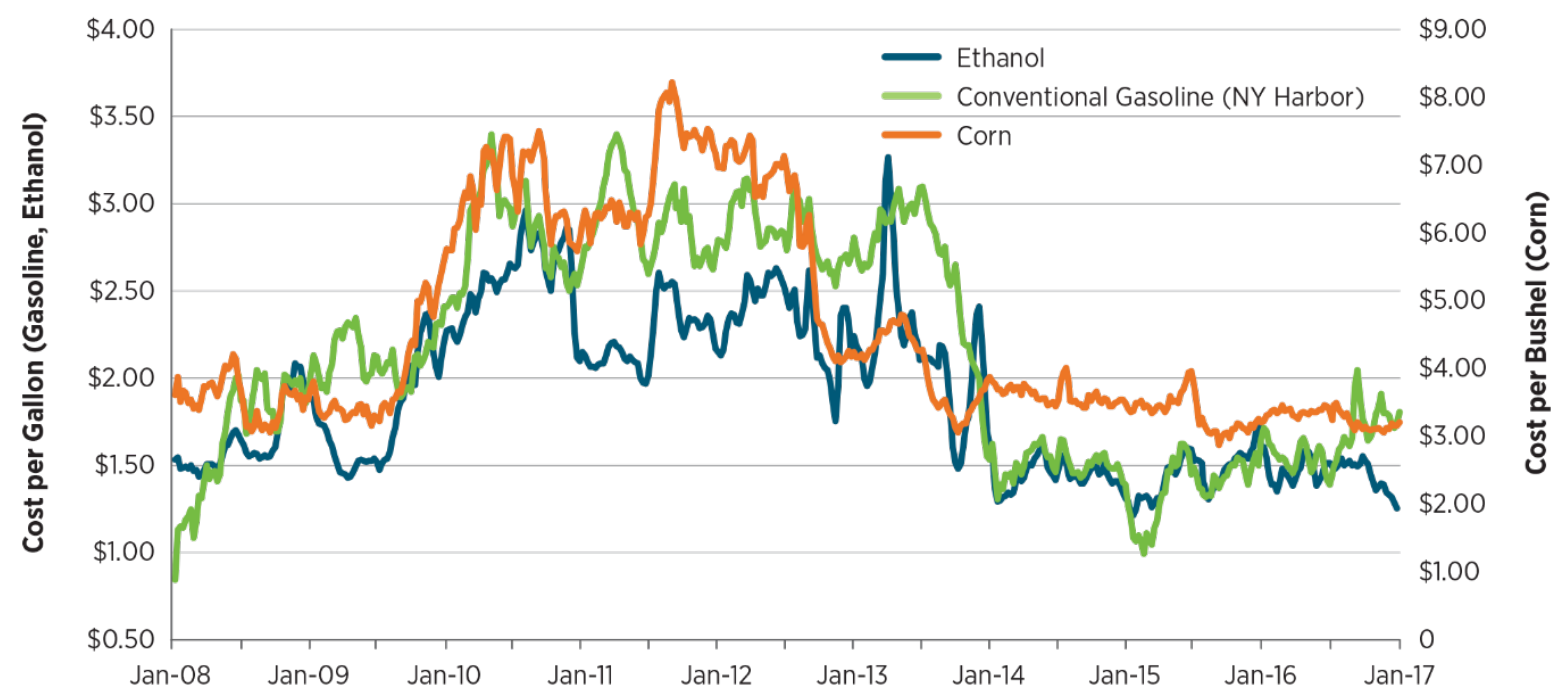

Figure 6. Historical corn, ethanol, and gasoline prices

Sources: Ethanol and Corn Grain: Ag Marketing Resource Center 2018; Gasoline: EIA 2018d. Note: Ethanol and gasoline are price per gallon, not energy equivalent. 


\subsubsection{Historical Production, Consumption, and Capacity}

Figure 7 highlights the tremendous growth in production and consumption of ethanol since 2008. Production has exceeded consumption in recent years, leading to increased exports. Figure 8 illustrates the rapid build-out of plants and capacity between 2008 and 2011. The number of plants operating at any given time is a function of economics and demand, and plants may idle at different times during the year depending on ethanol and corn grain prices. ${ }^{11}$ Installed corn ethanol capacity is capable of meeting the overall RFS renewable fuel category of 15 billion gallons. As of December 2017, there were 211 fuel ethanol plants in 28 states, with an installed capacity of over 16 billion gallons producing 15.7 billion gallons (Figure 9). Plant ownership is not consolidated - there are approximately 118 ownership organizations, but there are 4 companies that own $30 \%$ of plants and $38 \%$ of installed capacity: POET ( 27 plants; 1.6 billion gallons), Archer Daniels Midland (ADM) (8 plants; 1.7 billion gallons), Green Plains Renewable Energy (17 plants; 1.5 billion gallons), and Valero (11 plants; 1.4 billion gallons). Only nine ownership groups are traded publicly, and they account for $26 \%$ of plants and $34 \%$ of installed capacity (RFA 2018c). ${ }^{12}$

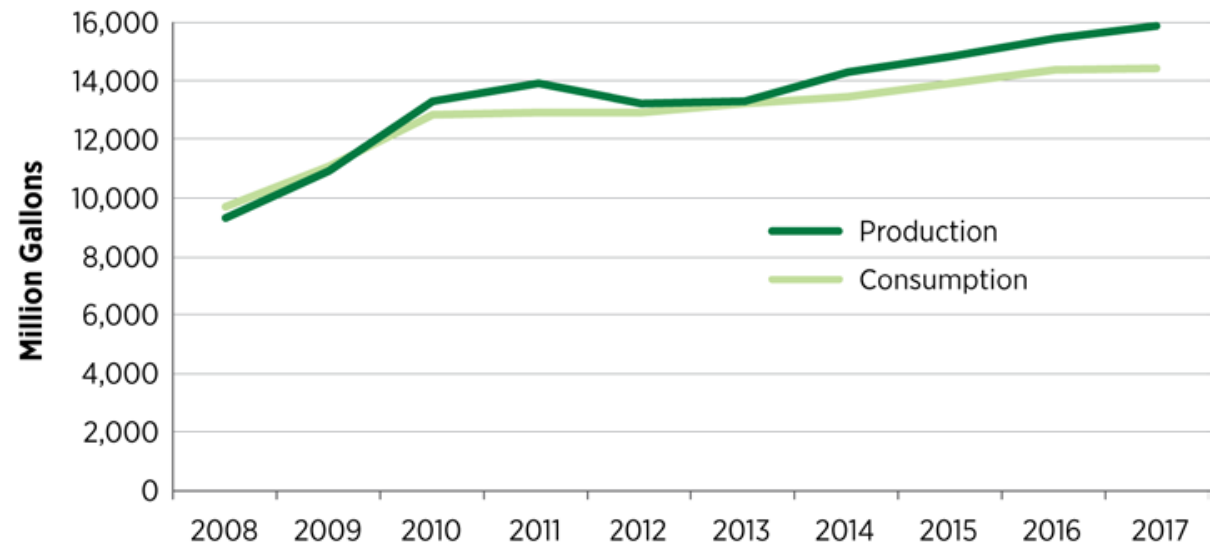

Figure 7. U.S. historical ethanol production and consumption

Source: EIA 2018a, Table 10.3

\footnotetext{
${ }^{11}$ The Renewable Fuels Association maintains a continuously updated list of installed and operating ethanol plants: http://www.ethanolrfa.org/resources/biorefinery-locations/.

${ }_{12}$ Public ethanol plant ownership companies include: Aemetis, ADM, CHS Inc., Green Plains Renewable Energy, Pacific Ethanol, REX American Resources, The Andersons, Inc., and Valero.
} 


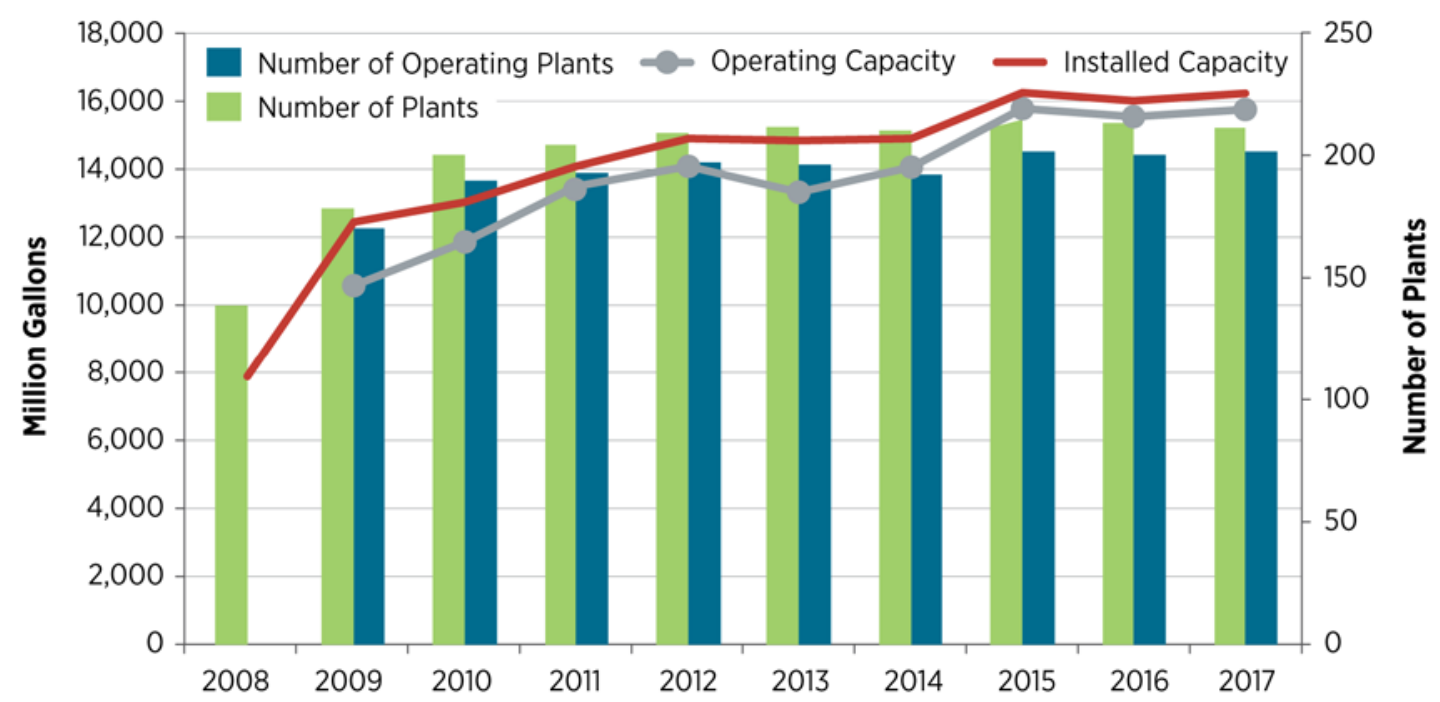

Figure 8. U.S. historical ethanol plants and capacity

Source: RFA 2018a

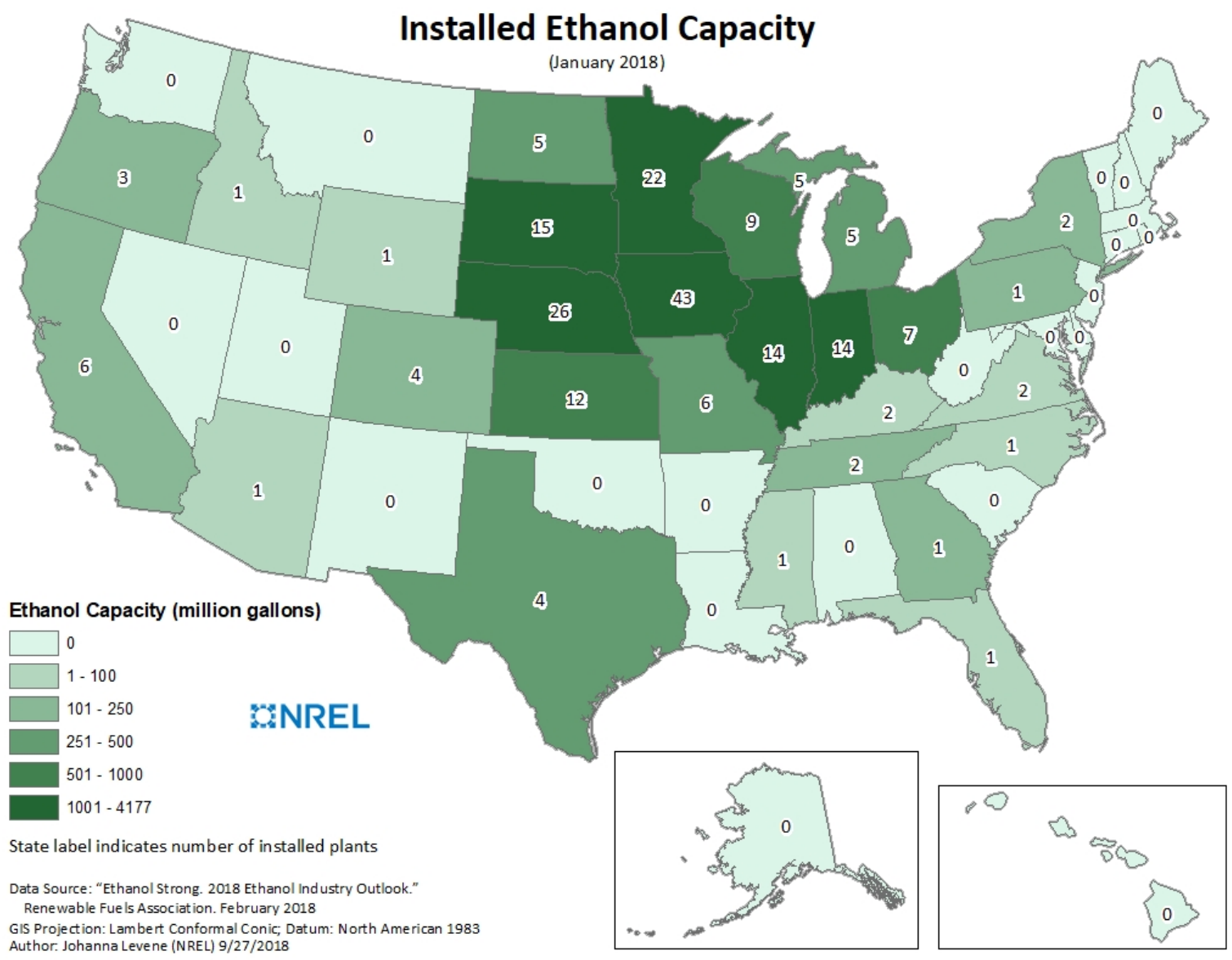

Figure 9. Ethanol plants by state (as of January 2018)

Source: RFA 2018a 


\subsubsection{Conventional Ethanol}

Conventional ethanol dominates the current ethanol market and meets the overall renewable fuel category of the RFS (D6 RIN). The majority of ethanol is produced using dry-mill technology (90\%); a small number of larger plants use a wet-milling process (10\%) (RFA 2018a). Dry milling is a process that grinds corn grain into flour and ferments only the starch component into ethanol with coproducts of distillers grains (an animal feed substitute) and carbon dioxide. Wetmill plants primarily produce corn grain sweeteners, along with ethanol and several other coproducts (such as corn oil and starch). Wet mills separate starch, protein, and fiber in corn grain prior to processing these components into ethanol and other products.

\subsubsection{Feedstocks}

In nearly all cases ethanol is made from corn grain (95\%), with a few mills using barley, grain sorghum, or wheat starch (3\%); 1\% using cellulosic biomass; and 1\% using food/beverage wastes (RFA 2018b). The United States is the world's largest corn grain producer. U.S. corn grain accounts for more than $95 \%$ of total feed grain production and use (USDA-ERS 2018a). Corn grain is grown in most states, with $61 \%$ of production concentrated in Iowa, Illinois, Nebraska, Minnesota, and Indiana (USDA 2018). Corn grain is also exported and processed into a wide range of industrial products. In 2017, corn grain used for ethanol accounted for about $38 \%$ of total corn grain production (USDA-ERS 2018b).

\subsubsection{Production Cost}

Because of the scarcity of data on the actual production cost of corn grain ethanol, economic models were developed to estimate production cost and track ethanol profitability. A model created by Iowa State University can be used to estimate the production cost for a typical northern Iowa natural-gas-fired ethanol plant with an annual capacity of 100 million gallons (Hofstrand 2018a). The plant represents similar facilities built around 2007 in Iowa but may not be representative of plants in other regions (Hofstrand 2018a). The estimated production cost, as shown in Figure 10, takes into account fixed costs, nonfeedstock variable costs (e.g., natural gas, chemicals, and labor), feedstock costs, and revenue contribution from coproduct(s) (dry distillers grains assumed by the model); the estimated production cost varied from $\$ 1.63 /$ gallon to \$3.47/gallon between 2008 and 2017 (Hofstrand 2018a). 


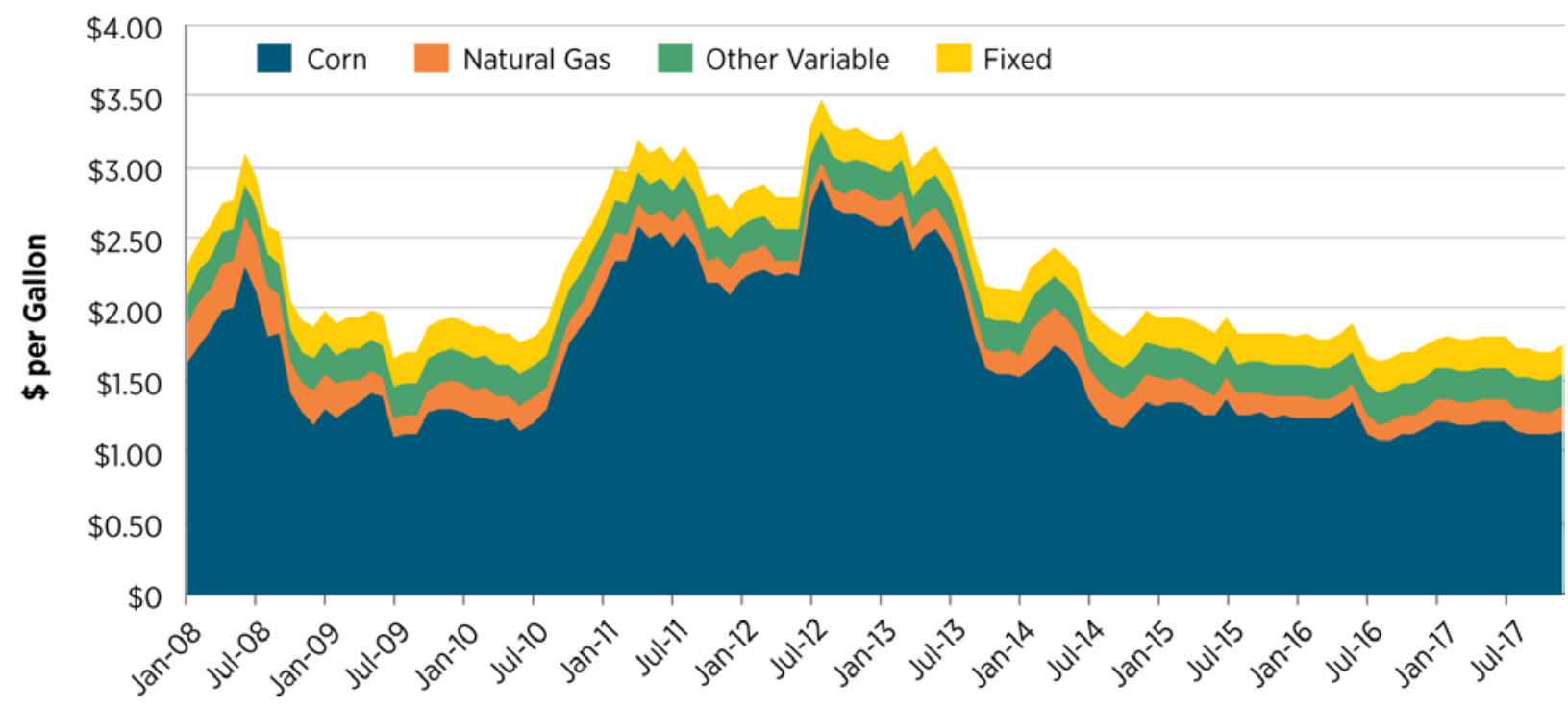

Figure 10. U.S. corn grain ethanol production cost trends

Source: Hofstrand 2018a

The single largest cost in the production of ethanol from corn grain is the cost of corn (Figure $10)$. Corn grain prices vary from year to year and have ranged from $\$ 3.36 /$ bushel to $\$ 6.89 /$ bushel, accounting for an average of $72 \%$ of production costs from 2008-2017 (USDAERS 2018a). ${ }^{13}$ Another major production cost contributor is the price of natural gas or other sources of heat needed for the conversion process. The market price of ethanol does not necessarily reflect the cost of ethanol production.

The largest ethanol markets are located on the East and West Coasts of the United States, outside of the primary corn grain production region. The majority of ethanol produced in the United States is shipped on trains to those markets because ethanol is not shipped by pipeline due to fuel properties. Ethanol prices are typically lowest in the Midwest and increase as a function of transportation costs when shipped to other domestic markets.

\subsubsection{Coproduct Overview}

Fuel ethanol coproducts from dry mills include distillers grains, ${ }^{14}$ corn gluten meal/feed, corn oil, and carbon dioxide. Coproducts contribution to gross revenues has grown significantly over the past decade, from $6 \%$ in 2007 to $21.5 \%$ in $2017 .^{15}$

\footnotetext{
${ }^{13}$ One bushel of corn grain $=56$ pounds; one bushel of corn grain yields approximately 2.8 gallons of ethanol. Price indicates price received by farmers.

${ }^{14}$ Distillers grains are sold in variations of two forms: wet distillers grains and dried distillers grains. Wet distillers grains have a short shelf life and are generally delivered to livestock operations within driving distance of ethanol plants. Dried distillers grains have a much longer shelf life and can be delivered to livestock operations throughout the country and exported.

${ }^{15}$ The data were provided by Renewable Fuels Association in an email on September 14, 2018, as they collect but do not publish those data.
} 
Corn grain is approximately two-thirds starch, which is converted into ethanol and carbon dioxide; the remaining one-third is protein and fat that are converted into distillers grains. Distillers grains are the highest volume coproduct and are sold as livestock feed, either wet (46 pounds/bushel at $65 \%$ moisture) or dry (18 pounds/bushel at $10 \%$ moisture). In 2017 , ethanol plants produced 37 million metric tons of distillers grains, 3.64 million metric tons of corn gluten feed, and 712 thousand metric tons of corn gluten meal (RFA 2018a). ${ }^{16}$ Pricing for distillers grains and corn oil is a function of corn grain price and is driven by demand in the markets ethanol producers serve. Distillers grains export markets have grown over time to supplement corn grain exports, with $29 \%$ of production exported to 50 countries in 2017 (Figure 11) (RFA 2018b). This was a $2 \%$ decrease compared to 2016 due to lower demand from China and Vietnam (RFA 2018d).

Approximately $90 \%$ of ethanol plants have added dry fractionation technology at the front end of their plant to extract nonedible corn oil at a rate of about 0.6 pounds/bushel, which is used as a feedstock for biodiesel plants or in animal feed (RFA 2017). Ethanol plants produced 3.6 billion pounds of corn oil in 2017 (RFA 2018d). USDA reports a marketing year 2016/17 inedible corn oil price of 28.13 cents/pound (USDA-ERS 2018c). Thirty-six ethanol plants sell carbon dioxide (6.6 pounds/gallon of ethanol) to industry for use in food and pharmaceutical products, and prices for raw carbon dioxide gas range from $\$ 5-\$ 25$ per short ton (hereafter referred to as "ton" unless otherwise specified) (Rushing 2011). More plants would likely sell carbon dioxide if they were near the end-user; however, most ethanol plants are located in rural areas.

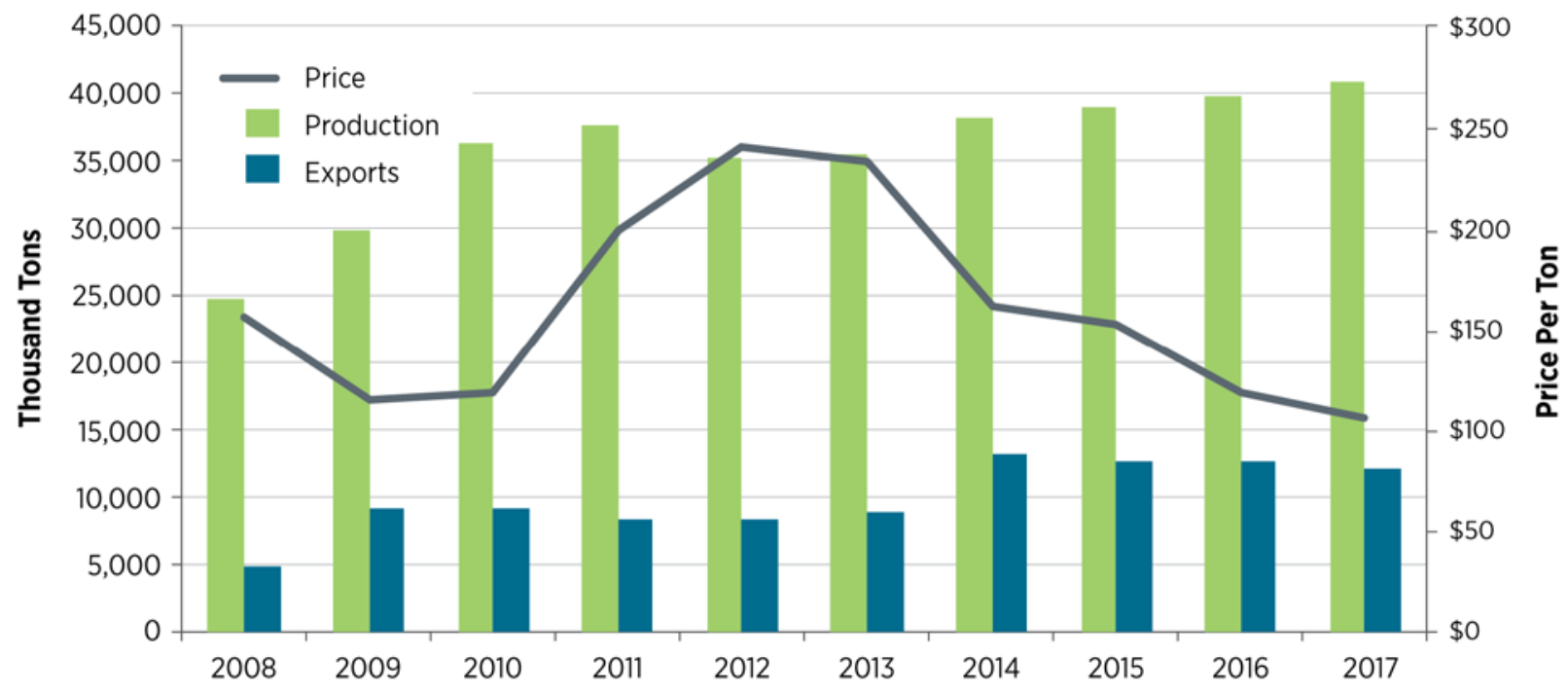

Figure 11. U.S. starch ethanol distillers grains production, trade, and price

Sources: Production: RFA 2018d; Exports: RFA 2018d; Prices at Production Facilities (annual average of prices at production facilities in lowa, Illinois, Nebraska, South Dakota, and Wisconsin): Ag Marketing Resource Center 2018

\subsubsection{Economic Impacts of Ethanol}

The economic impact of corn grain ethanol is significant, particularly among the states where ethanol plants are located and corn grain production increases, partially because of rising demand

\footnotetext{
${ }^{16}$ All coproducts converted to $10 \%$ moisture basis.
} 
for ethanol production. Processing raw corn grain into ethanol adds value to the feedstock through activities that support the necessary investment in processing, marketing, construction, and research and development.

The ethanol industry funds annual studies to determine the impacts of ethanol production on the economy (most recently Urbanchuk [2018]). These studies applied an economic input-output model known as IMPLAN, or IMpact analysis for PLANning, to estimate gross value added (total value of the goods and services produced by businesses), income, and employment resulting from the corn grain ethanol industry each year.

- Ethanol contribution to gross domestic product increased from $\$ 17.7$ billion in 2005 to $\$ 44.4$ billion in 2017.

- The number of direct jobs has declined somewhat in the past 11 years, from 87,883 during the rapid build-out of plants in 2005 to 71,906 in $2017 .{ }^{17}$

- The contribution of federal tax revenue grew from $\$ 1.9$ billion in 2005 to $\$ 5$ billion in 2017. State and local government tax revenue was $\$ 5.7$ billion in 2017.

\subsubsection{Cellulosic Ethanol Production}

As the corn grain ethanol industry has matured, interest has moved toward using nonfood cellulosic feedstocks, such as crop residues, waste wood, municipal solid waste (MSW), and dedicated energy crops to produce ethanol. Ethanol made from cellulosic feedstock meets the same ASTM International (ASTM) fuel quality standards as conventional ethanol and has the same performance in vehicles. Commercial deployment of cellulosic biofuels has been challenging, particularly due to the high startup risks for these new technologies. These risks include feedstock availability, collection, and delivery; pretreatment technology costs; higher capital costs; and technology scale-up challenges.

Cellulosic ethanol is produced via biochemical, thermochemical, and hybrid technology pathways. In the biochemical pathway, cellulose and hemicellulose in the feedstock are deconstructed into simple sugars through various pretreatment processes and enzymes. Microbes are used to ferment the sugars into ethanol. The thermochemical pathway uses heat to transform the feedstock into a synthesis gas (syngas), comprised of hydrogen and carbon monoxide, that is catalytically converted to ethanol, other alcohols, and oxygenated intermediates. Hybrid technologies use a combination of biochemical and thermochemical operations - for example, syngas fermentation thermochemically deconstructs the feedstock into syngas, which microbes ferment into fuel or bioproducts.

The majority of cellulosic ethanol produced was made via the conversion of corn fiber. In 2014, EPA qualified corn fiber, a byproduct of first-generation ethanol production that makes up roughly $10 \%$ corn kernel dry weight, under the RFS as a cellulosic biofuel feedstock for the production of ethanol. Conversion of corn fiber to cellulosic ethanol is a multiple-step process. Much like the production of ethanol from lignocellulosic biomass, the first step requires the

\footnotetext{
17 The jobs estimated in Urbanchuk (2018) are different than job estimates in the U.S. Department of Energy's 2017 U.S. Energy and Employment Report; the latter relied on surveys, which can result in lower numbers.
} 
pretreatment of the fiber to modify the underlying crystalline structure to allow for conversion via enzymatic hydrolysis to monomeric sugars. However, unlike lignocellulosic feedstock, the composition of the corn fiber is low in lignin, and the treatment for fiber tends to be much milder and requires lower enzyme loadings (BioRefineries Blog 2017). Unlike starch ethanol production, where the sugar is only $\mathrm{C} 6$, the sugar produced from the corn fiber is a mixture of $\mathrm{C} 5$ and C6 sugars that are converted into ethanol. Multiple companies have developed bolt-on technologies for converting residual corn fiber in first-generation ethanol facilities. As of 2017, six ethanol plants were producing cellulosic ethanol from corn fiber, while another nine plants were under construction to add the bolt-on technology.

Despite challenges in technology development, investment constraints from the 2008 recession, and market conditions for ethanol, the industry is seeing the first commercial-scale cellulosic ethanol plants being built. U.S. cellulosic ethanol production capacity was $1.1 \%$ of total ethanol capacity in 2017 (RFA 2018a). EPA reports (Figure 12) over 10 million gallons of cellulosic ethanol in 2017: a 164\% increase compared to 2016 (EPA 2018a).

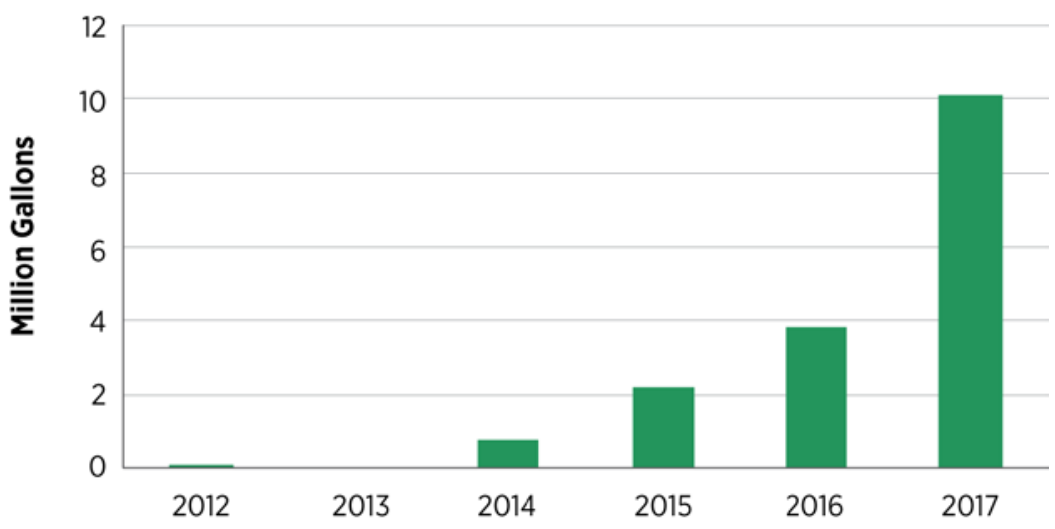

Figure 12. U.S. historical cellulosic ethanol production

Source: EPA 2018a

\subsubsection{Feedstocks}

Cellulosic ethanol can be produced from various nonfood cellulosic feedstocks, such as crop residues, woody materials (e.g., forest residues), MSW, and dedicated energy crops. The 2013 Bioenergy Market Report illustrates that about 400 million dry tons of cellulosic biomass resources are generated annually in the United States (Schwab et al. 2016). The 2016 Billion-Ton Report provides estimates on feedstock quantity and price from 2017 to 2040 under several alternative assumptions about achievable future yields (DOE 2016a). Projections have suggested that 1.5 billion gallons of ethanol could be produced from the available 12 million tons of corn fiber currently available in U.S. dry-mill facilities (Syngenta 2017). Adding cellulosic ethanol conversion technology to existing corn ethanol plants allows these facilities to diversify their portfolios by producing cellulosic ethanol in addition to corn ethanol and thus qualify for cellulosic RINs in the RFS.

\subsubsection{Commercialization of Cellulosic Ethanol}

A variety of sources were used to determine the status of cellulosic ethanol plants, both commercial and those in the demonstration- and pilot-scale stages. Past year survey data were 
used, as well as data from the International Energy Agency and media reports, and by contacting ethanol plant owners.

Table 1 summarizes commercial cellulosic ethanol projects identified during the survey. ${ }^{18}$ In 2017, the United States had approximately 30 million gallons per year (MMGY) of cellulosic ethanol production capacity. All of these plants use an acid or enzymatic (A/E) pretreatment followed by fermentation technology. The most common feedstock is corn kernel cellulose. DuPont exited the cellulosic market in 2017, taking its 30 MMGY plant offline.

Commercial-scale plants include:

- Operating (7): The reported installed capacity of the plants was 29.6 MMGY. POET's plant is the sole standalone operating plant with a capacity of $20 \mathrm{MMGY}$. The other six are producing cellulosic ethanol from corn fiber with Edeniq's technology at their existing corn ethanol plants (Flint Hills-Shell Rock, Little Sioux Corn Processors, Mid America Agri Products, Pacific Ethanol, Quad County Corn Processors, and Siouxland Energy). The capacity at plants extracting corn fiber tends to be low, ranging from 1 to 3 MMGY.

- Under Construction (9): The total reported under-construction capacity was 71.5 MMGY. Seven existing corn ethanol plants are adding corn fiber extraction with an expected combined capacity of 26.5 MMGY. Plants adding corn fiber extraction include Ace Ethanol (D3MAX technology), Flint Hills (three plants, Edeniq technology), and Pacific Ethanol (two plants, Edeniq technology). Element, a joint venture between ICM, Inc. and The Andersons, Inc., is building a new ethanol plant to showcase advanced technologies, and the total capacity is expected to be $70 \mathrm{MMGY}$ with $7 \mathrm{MMGY}$ of the capacity dedicated to corn fiber extraction and cellulosic ethanol production. Amentis is constructing a 45-MMGY plant that will use nut wastes as the feedstock. Fiberight's plant will use MSW as a feedstock and expected capacity is 6 MMGY.

\footnotetext{
${ }^{18}$ The plants listed in Table 1 represent plants listed at the time that this report was prepared.
} 
Table 1. Commercial Cellulosic Ethanol Plants

\begin{tabular}{|c|c|c|c|c|c|}
\hline Project Name & Location & $\begin{array}{l}\text { Capacity } \\
\text { (million } \\
\text { gallons) }\end{array}$ & Feedstock & Deconstruction Technology & Upgrade Technology \\
\hline \multicolumn{6}{|c|}{ OPERATIONAL } \\
\hline Flint Hills & Shell Rock, IA & 3 & corn fiber cellulose & acid/enzymatic & fermentation \\
\hline Little Sioux Corn Processors & Marcus, IA & 1.5 & corn fiber cellulose & acid/enzymatic & fermentation \\
\hline Mid America Agri Products & Madrid, NE & 1 & corn fiber cellulose & acid/enzymatic & fermentation \\
\hline Pacific Ethanol & Stockton, CA & 1 & corn fiber cellulose & acid/enzymatic & fermentation \\
\hline POET-DSM & Emmetsburg, IA & 20 & crop residues & acid/enzymatic & fermentation \\
\hline Quad County Corn Processors & Galva, IA & 2.1 & corn fiber cellulose & acid/enzymatic & fermentation \\
\hline Siouxland Energy & Sioux Center, IA & 1 & corn fiber cellulose & acid/enzymatic & fermentation \\
\hline \multicolumn{6}{|c|}{ UNDER CONSTRUCTION } \\
\hline Ace Ethanol & Stanley, WI & 3 & corn fiber cellulose & acid/enzymatic & fermentation \\
\hline Aemetis & Keyes, CA & 45 & nut wastes & gasification & fermentation \\
\hline Element & Colwich, KS & 7 & corn fiber cellulose & acid/enzymatic & fermentation \\
\hline Fiberight & Hampden, ME & 6 & municipal solid waste & acid/enzymatic & fermentation \\
\hline Flint Hills & Fairbank, IA & 3 & corn fiber cellulose & acid/enzymatic & fermentation \\
\hline Flint Hills & lowa Falls, IA & 2.5 & corn fiber cellulose & acid/enzymatic & fermentation \\
\hline Flint Hills & Menlo, IA & 3 & corn fiber cellulose & acid/enzymatic & fermentation \\
\hline Pacific Ethanol & Magic Valley, ID & 1 & corn fiber cellulose & acid/enzymatic & fermentation \\
\hline Pacific Ethanol & Madera, CA & 1 & corn fiber cellulose & acid/enzymatic & fermentation \\
\hline
\end{tabular}

Sources: Warner, Schwab, and Bacovsky 2017; International Energy Agency advanced biofuel plant list (provided to NREL); industry contact; and media reports

Table 2 summarizes precommercial (pilot- and demonstration-scale) nonstarch alcohol projects. ${ }^{19}$ In 2017, four demonstration and seven pilot projects were operating. The majority of the demonstration and pilot projects involve $\mathrm{A} / \mathrm{E}$ pretreatment and fermentation, with two plants employing technologies that use gasification followed by catalytic upgrading for the use of fermentation upgrading. The majority of projects are using woody biomass feedstocks, while some are using MSW or crop residues.

19 The plants listed in Table 2 represent plants listed at the time that this report was prepared. 
Table 2. Precommercial Nonstarch Ethanol Facilities in 2017

\begin{tabular}{|c|c|c|c|c|}
\hline Project Name & Location & Feedstock & Deconstruction Technology & Upgrade Technology \\
\hline Earth Energy Renewables & Bryan, TX & municipal solid waste & acid/enzymatic & fermentation \\
\hline Fiberight & Lawrenceville, VA & municipal solid waste & acid/enzymatic & fermentation \\
\hline GranBio & Alpena, MI & woody biomass & & syngas catalytic \\
\hline LanzaTech & Soperton, GA & woody biomass & gasification & fermentation \\
\hline NREL & Golden, CO & crop residues & acid/enzymatic & fermentation \\
\hline POET & Scotland, SD & crop residues & acid/enzymatic & not reported \\
\hline Renmatix & Kennesaw, GA & woody biomass & acid/enzymatic & fermentation \\
\hline Summit Natural Energy & Cornelius, OR & municipal solid waste & acid/enzymatic & fermentation \\
\hline Sweetwater Energy & Rochester, NY & woody biomass & acid/enzymatic & syngas catalytic \\
\hline West Biofuels & Woodland, CA & woody biomass & gasification & fermentation \\
\hline Zeachem & Boardman, OR & woody biomass & acid/enzymatic & \\
\hline
\end{tabular}

Sources: Warner, Schwab, and Bacovsky 2017; International Energy Agency advanced biofuel plant list (provided to NREL); industry contacts; and media reports

\subsubsection{Production Costs and Economic Impacts}

Available data on cellulosic ethanol production costs are limited due to the number of companies producing cellulosic ethanol. One study estimates that fuel production costs for cellulosic ethanol are about $\$ 5.90 /$ gasoline gallon equivalent (gge), ranging between $\$ 5.06$ and $\$ 6.73 /$ gge, and estimated potential costs are $\$ 4.69 /$ gge, ranging between $\$ 4.18$ and $\$ 4.88 /$ gge, for 2025 .

Due to limitations of current cost estimates, Figure 13 and Figure 14 illustrate modeled longerterm future cellulosic ethanol production costs. These figures illustrate how significant technology developments over the last few decades are enabling cost-competitive cellulosic ethanol to come to commercial-scale production. In 2012, researchers at the National Renewable Energy Laboratory (NREL), Pacific Northwest National Laboratory, and Idaho National Laboratory, funded through the U.S. Department of Energy (DOE), successfully modeled—at significant scale - two cellulosic ethanol production processes at a projected mature commercialscale cost for the $\mathrm{n}^{\text {th }}$ plant. ${ }^{20}$ The production of ethanol via lignocellulosic sugars derived from corn stover resulted in an $\mathrm{n}^{\text {th }}$-plant price of an estimated $\$ 2.45$ per gallon (2014 dollars), whereas the catalytic upgrading of syngas produced via indirect gasification of woody biomass resulted in an $\mathrm{n}^{\text {th }}$-plant model price of \$2.34 per gallon (2014 dollars) (Tao et al. 2014; Dutta et al. 2011). Based on the assumptions in these design case reports, calculated costs included feedstock harvesting, transportation, and integrated conversion. The model was validated at integrated pilot scale and met the goals set by DOE's Advanced Energy Initiative of 2006 to show that cellulosic ethanol could be cost competitive with corn grain ethanol and conventional fuels. Continued research may further decrease production costs. For example, in 2013, a partnership between Idaho National Laboratory and Iowa State University achieved critical corn stover feedstock processing targets that enable cost-competitive biofuels and identified best practices for replication with a variety of herbaceous feedstocks. DOE-funded industry research also has resulted in commercially viable strains of yeast, bacteria, and enzymes for biochemical conversion and catalysts for thermochemical conversion (Tao et al. 2014; Dutta et al. 2011).

\footnotetext{
${ }^{20}$ The $^{\text {th }}$ plant represents the deployment of a mature technology once several plants have already been built and operated.
} 
These and other such improvements are expected to be implemented in newly constructed cellulosic ethanol biorefineries.

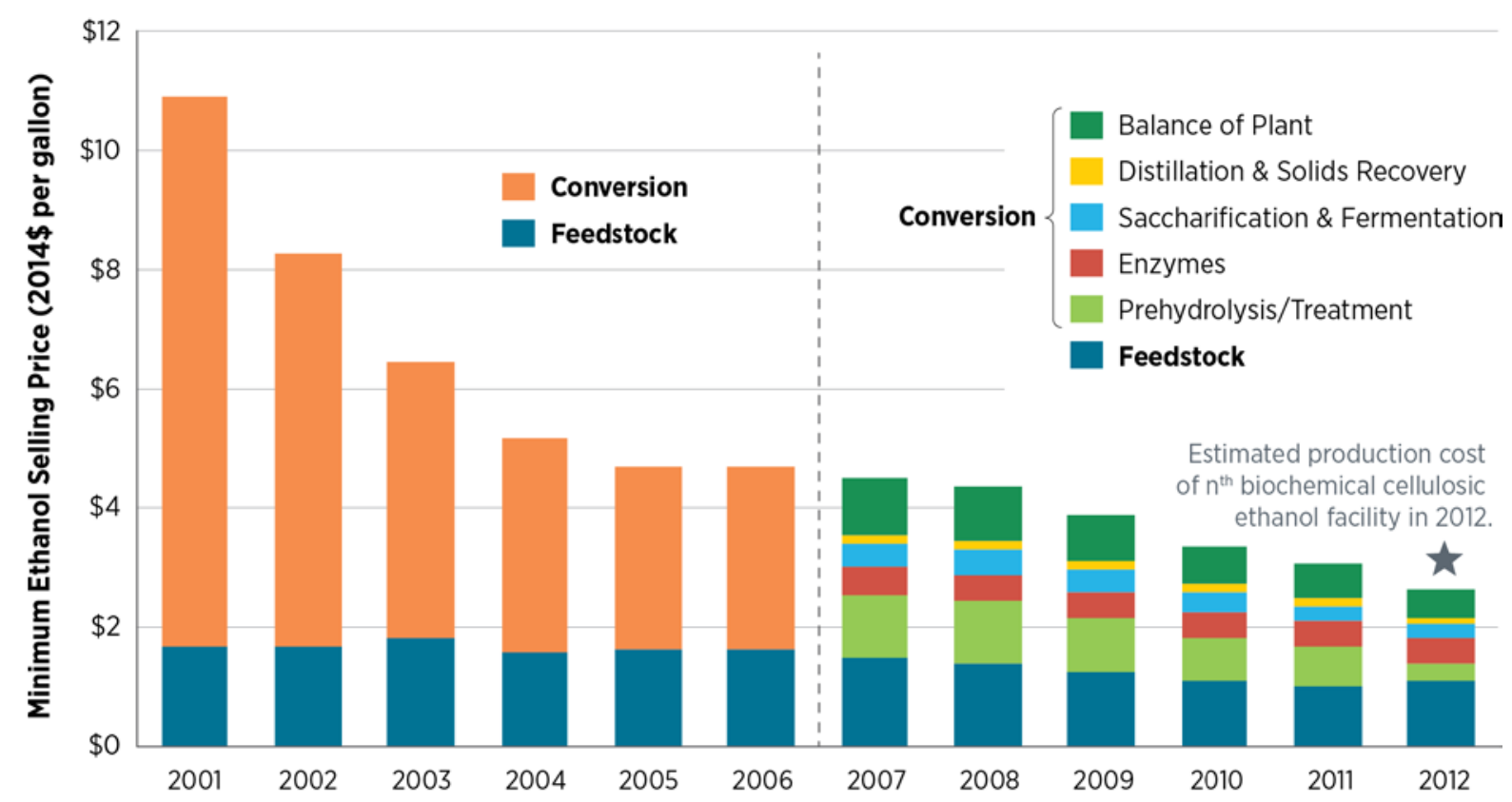

Figure 13. Biochemical cellulosic ethanol modeled production costs over time

Source: Humbird et al. 2011

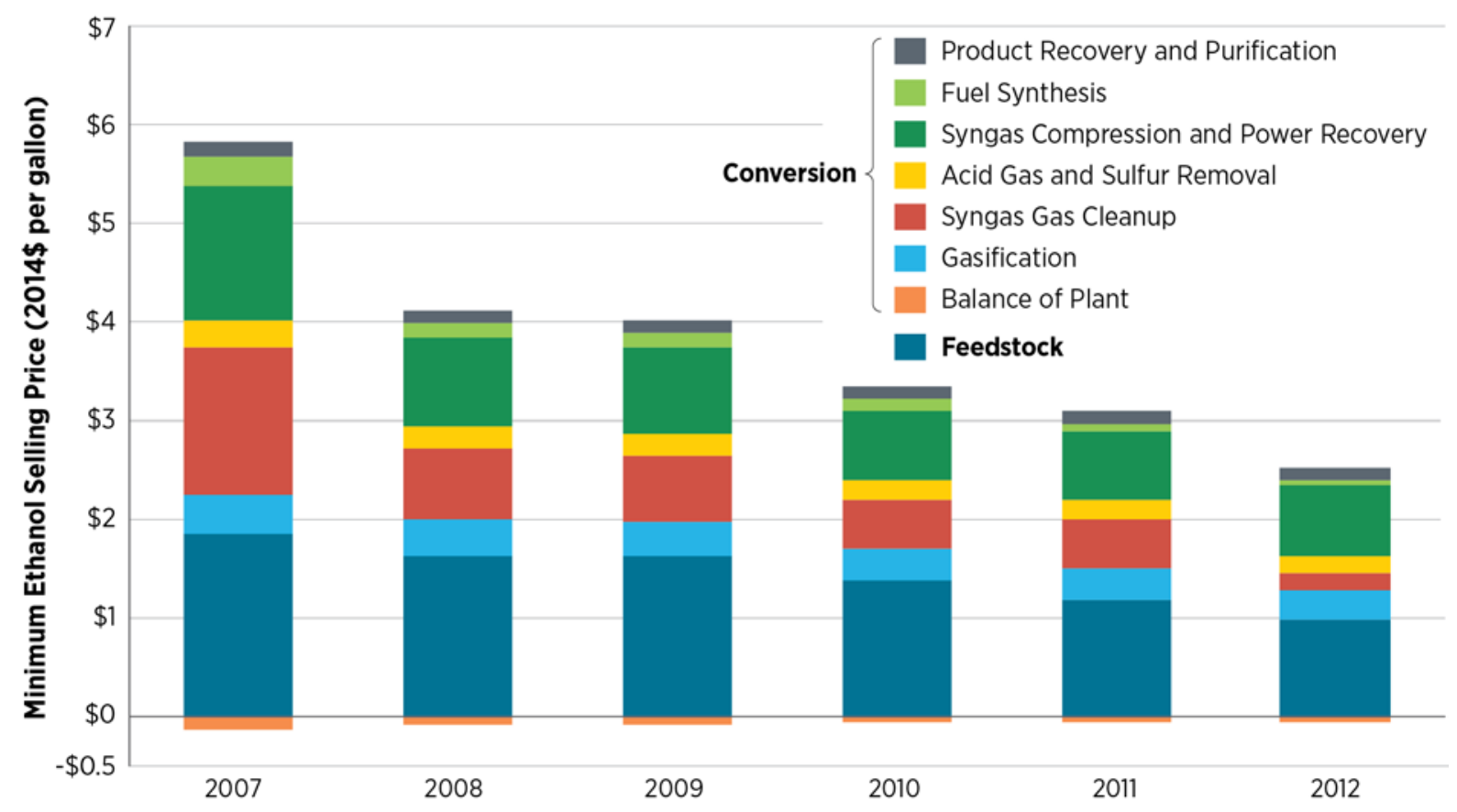

Figure 14. Thermochemical cellulosic ethanol modeled production costs over time Source: DOE $2016 b$ 
Techno-economic modeling analyses suggest that cellulosic ethanol facilities with a capacity of about 60 MMGY are expected to hire approximately 60 on-site workers for an $\mathrm{n}^{\text {th }}$ plant (Dutta et al. 2011; Humbird et al. 2011). Labor requirements will depend on which conversion process is employed, system configuration, size of the facility, and other factors such as the feedstock type and handling. Cellulosic ethanol will also result in jobs for those gathering and delivering feedstock and other inputs and equipment to the plant.

\subsubsection{Coproducts Overview}

The petroleum refinery industry and first-generation ethanol producers have utilized the coproduction of fuels and value-added products for decades to improve economic viability of these integrated process designs. In 2015, DOE's Bioenergy Technologies Office (BETO) held a workshop focused on bioproducts to enable biofuels to engage stakeholders on the current state of technology and research and development needs for the co-development of fuels and chemicals (DOE 2015a). Further, BETO has supported development of additional analyses to consider production from biomass and market opportunities for these emerging products (Biddy et al. 2016). In current process designs for the biological conversion of cellulose- and hemicellulose-derived sugars to ethanol, lignin is burned to generate process heat and electricity, with any excess power produced being sold as a coproduct. The exported electricity improves the profitability of the process and provides ancillary benefits by displacing fossil-derived electricity and potentially reducing GHG emissions (Wyman 2003; Humbird et al. 2011). As highlighted in a recent review article on lignin valorization, there are extensive opportunities for further improvements in the overall economic and environmental outcomes of a biorefinery complex via utilization of all the components of biomass (Ragauskas et al. 2014). This potential economic and environmental improvement for an integrated biorefinery was investigated in the NREL design report (Davis et al. 2013) that focused on the biological conversion of cellulosic sugars to hydrocarbon fuels. In this study, the conversion of lignin to products, including 1,4-butanediol and adipic acid, resulted in improving the overall process economics, as well as potentially reducing the GHG emissions relative to the production of electricity from lignin (Davis et al. 2013). Continued research and development in catalysis and improvements in process integration may address the challenges and barriers for the conversion of lignin to fuels and chemicals.

\subsubsection{Policies That Affect the Ethanol Market}

Ethanol received significant government support under federal law in the form of mandated biofuel use, tax incentives, loan and grant programs, and other regulatory requirements. ${ }^{21}$ The ethanol market has expanded due to both regulation and market factors. Federal regulations that have influenced the market include a series of federal and state tax incentives; the National Energy Act of 1978, which helped grow what was a small startup industry; the RFS in the Energy Policy Act of 2005, which mandated blending 7.5 billion gallons of biofuel with gasoline annually by 2012; and EISA in 2007, which expanded the RFS to 36 billion gallons by 2022 . Another significant market driver was the replacement of MTBE with ethanol as an octane source in gasoline blending. MTBE was previously used to increase octane, but concerns about

\footnotetext{
${ }^{21}$ This section covers federal incentives and policies. States also may have incentives and policies. This information is available from the "Laws and Incentives" section of the Alternative Fuels Data Center (AFDC) website:

http://www.afdc.energy.gov/laws.
} 
groundwater contamination caused some states to ban its use in 2005 and 2006. MTBE exited the market and was replaced with ethanol.

A number of federal incentives for ethanol producers and blenders expired at the end of 2011, including the Volumetric Ethanol Excise Tax Credit (VEETC), a small ethanol producer tax credit, and an import tariff for fuel ethanol. The tariff on imported ethanol gave domestic producers a competitive advantage over foreign producers (Pelkmans, Govaerts, and Kessels 2008). Initially, the federal government subsidized ethanol by exempting ethanol gasoline blends from excise taxes and establishing a tax credit for ethanol use in the late 1970s. In 2004, the American Jobs Creation Act implemented the VEETC to replace the two historical subsidies as a combined excise tax exemption and tax credit (Taxpayers for Common Sense 2011). The tax credit was paid to ethanol blenders (petroleum companies) rather than ethanol plants, though the ethanol price was certainly impacted by the tax credit. The value of the tax credit was \$0.51/gallon from 2004 through 2008 and \$0.45/gallon between 2009 and 2011 (Kim, Schaible, and Daberkow 2010). The VEETC was discontinued at the end of 2011 because conventional ethanol had reached commercial maturity and the incentive was no longer necessary. Table 3 shows the historical VEETC federal support for ethanol.

\section{Table 3. Historical VEETC Federal Investment}

\begin{tabular}{|c|c|}
\hline Year & VEETC (billion\$) \\
\hline 2004 & 1.7 \\
\hline 2005 & 2.0 \\
\hline 2006 & 2.5 \\
\hline 2007 & 3.3 \\
\hline 2008 & 4.7 \\
\hline 2009 & 4.9 \\
\hline 2010 & 6.0 \\
\hline 2011 & 6.3 \\
\hline
\end{tabular}

Source: EIA 2018a, Table 10.3. Calculated by multiplying ethanol production by tax incentive (\$0.51/gallon for 20042008 and $\$ 0.45 /$ gallon for 2009-2011).

Cellulosic ethanol also received significant government support under federal law in the form of biomass grower payments, the RFS cellulosic fuel requirement, tax incentives, loan and grant programs, and other regulatory requirements. The most significant regulatory driver for cellulosic ethanol production has been the RFS. However, given the industry's slow startup, production has been lower than originally projected, resulting in yearly reductions by EPA of the cellulosic RVO. Other policy supports include grants through BETO for first-of-a-kind biorefineries using biomass feedstocks, as well as payments to biomass feedstock growers under the USDA Biomass Crop Assistance Program. ${ }^{22}$ Loan guarantees are available for cellulosic ethanol plants through DOE and USDA. A cellulosic biofuel production tax credit of

\footnotetext{
${ }^{22}$ For more information on integrated biorefinery projects, visit http://www.energy.gov/eere/bioenergy/integratedbiorefineries.
} 
\$1.01/gallon expired at the end of 2013 and was extended retroactively through the end of 2014, when it once again expired.

\subsubsection{Ethanol Trade}

Ethanol is both imported and exported as a function of demand or biofuel use requirements in other nations (Figure 15). The United States is the world leader in ethanol production, accounting for 56\% of 2017 world production (RFA 2018e). In 2017, 77 million gallons imported were imported including sugarcane ethanol from Brazil, which qualifies as an advanced biofuel under the RFS, and the remainder was from Canada (EIA 2018e). Eighty-nine percent of imports enter the United States through the port of San Francisco (RFA 2018f). The United States exported nearly 1.4 billion gallons valued at $\$ 2.4$ billion in 2017 , which was $8.7 \%$ of U.S. ethanol production and a 16\% increase over 2016 exports (RFA 2018f). Exports were to 42 nations and the United States' three largest trading partners were Brazil (31\%), Canada (23\%), and India (13\%) (EIA 2018f). The majority of exports leave out of the ports of Houston/Galveston (46\%), New Orleans (22\%), and Detroit (13\%).

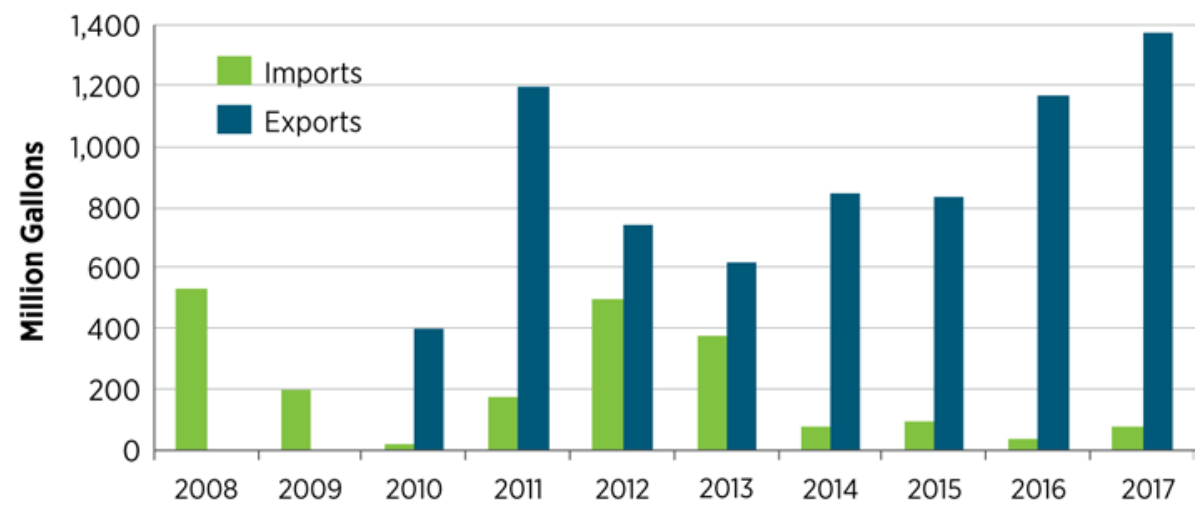

Figure 15. U.S. ethanol imports and exports

Sources: EIA 2018e; EIA 2018f

\subsubsection{Infrastructure}

Infrastructure is a critical part of the supply chain in deploying alternative transportation fuels. Significant research and outreach activities have resulted in blends above E10 being used in both specifically designed equipment and existing refueling equipment. Regulations have long accommodated the use of E10 in existing infrastructure. Blends above E10 require some specialized equipment to meet the patchwork of regulations that cover refueling infrastructure. Codes and standards for refueling agencies are developed and enforced by many organizations, including EPA's Office of Underground Storage Tanks, authorities having jurisdiction (typically fire marshals), UL (a third-party safety certification organization), the Occupational Safety and Health Administration, fire safety code organizations, and industry groups.

EPA's Office of Underground Storage Tanks is responsible for federal codes for fuel storage, and it updated federal code in July 2015 that requires stations to demonstrate compatibility when 
storing biofuel blends above E10 or B20 (20\% biodiesel, $80 \%$ petroleum diesel). ${ }^{23}$ The majority of installed tanks and pipes are compatible with ethanol blends up to E85 or E100 (neat ethanol), and UL-listed above-ground equipment for blends above E10 became available in 2010. Stations interested in selling ethanol blends can refer to Clean Cities' Handbook for Handling, Storing, and Dispensing E85 and Other Ethanol-Gasoline Blends, which explains requirements for selling ethanol blends and provides lists of compatible and UL-listed equipment. ${ }^{24}$

As of the end of 2017, E85 was available at 3,379 stations in 42 states (Figure 16 and Figure 17); however, there are often low densities of E85 stations in areas with high concentrations of capable vehicles (AFDC 2018b) ${ }^{25}$ It is possible that E85 sales could increase if more E85 stations were located in areas with high concentrations of FFVs, but only when the price is discounted to reflect the lower energy density of ethanol compared with gasoline. As of the end of 2017, there were 1,200 stations in 30 states selling E15 (Growth Energy 2018). USDA's Biofuels Infrastructure Partnership program resulted in more stations offering E15 and E85 in 2017.

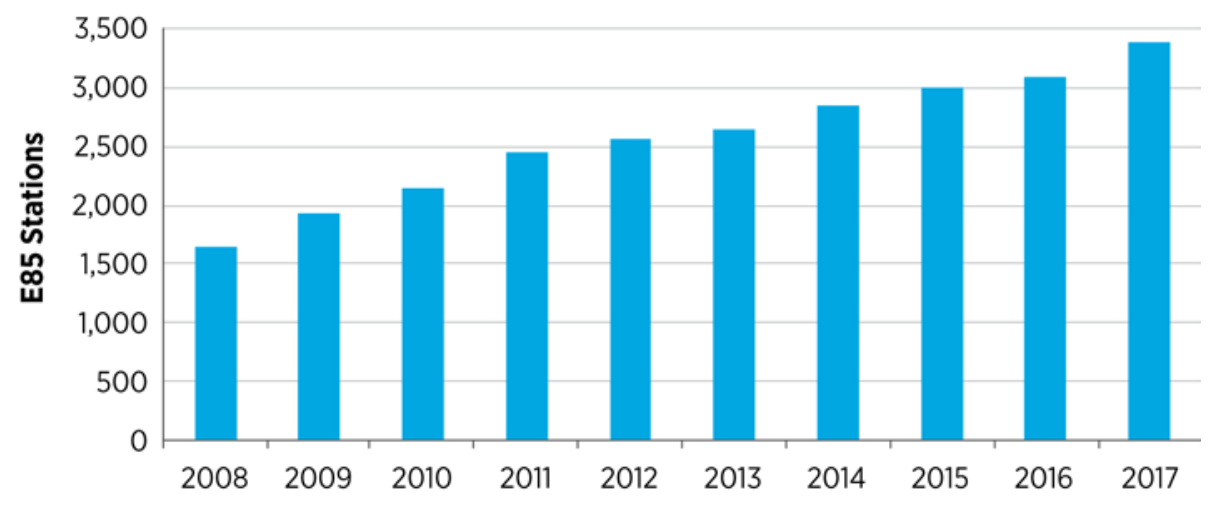

Figure 16. U.S. historical E85 stations

Source: AFDC 2018c

\footnotetext{
${ }^{23}$ For more information, visit http://www.ecfr.gov/cgi-bin/text-idx?tpl=/ecfrbrowse/Title40/40cfr280 main_02.tpl.

${ }^{24}$ Clean Cities' Handbook for Handling, Storing, and Dispensing E85 and Other Ethanol-Gasoline Blends provides lists of compatible tanks, pipes, and associated underground storage tank equipment, as well as UL-listed dispensers and hanging hardware: http://www.afdc.energy.gov/uploads/publication/ethanol handbook.pdf.

${ }^{25}$ TransAtlas shows locations of both alternative fuel stations and vehicles: http://maps.nrel.gov/transatlas.
} 


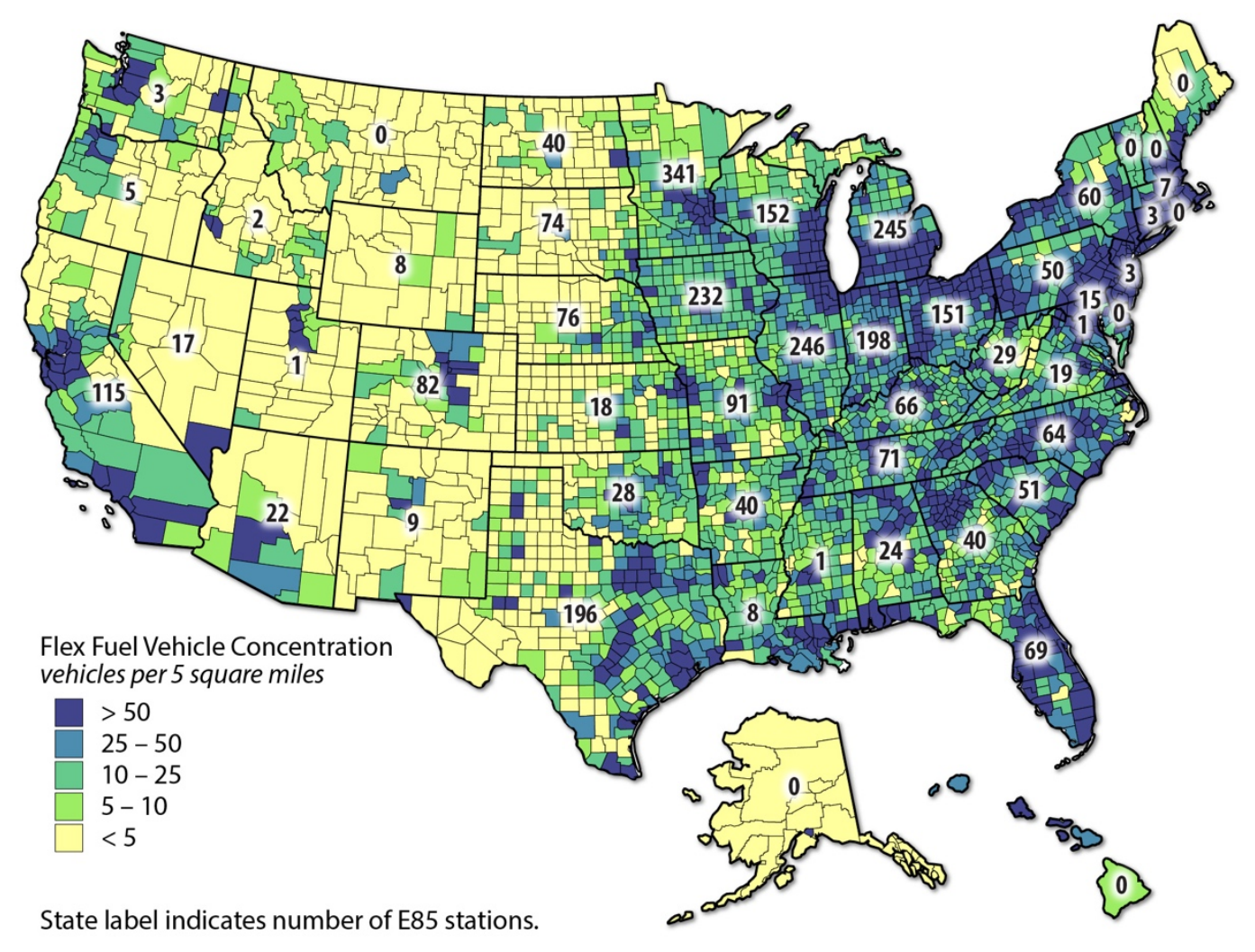

Figure 17. E85 stations and FFV locations by county

Sources: Vehicles: IHS Automotive (2016 data), https://www.ihs.com/btp/polk.html; Stations: AFDC 2018b

\subsubsection{End Use}

All 234 million U.S.-registered light-duty gasoline vehicles are able to operate on E10. MY 2001 and newer light-duty trucks and vehicles are approved by EPA to operate on E15. At the end of 2017, 94\% of the gasoline light-duty truck and vehicle population was MY 2001 and newer; however, some manufacturers approve the use of E15 in their vehicles while others do not. ${ }^{26}$

FFVs are capable of operating on any gasoline-ethanol blended fuel between E0 and E85, and there were more than 20 million FFVs on U.S. roads at the end of 2017 (Figure 17 and Figure 18). For MY 2017, there were 42 models from 6 manufacturers. ${ }^{27}$ The National Highway Traffic Safety Administration establishes CAFE standards, and auto manufacturers receive a credit for each FFV sold, which helps them meet the overall regulation. Sales and production of FFVs are driven more by auto manufacturers' desire to obtain a CAFE credit than by demand from customers (Barrionuevo and Maynard 2006). Currently, manufacturers do not have to demonstrate if FFVs were using E85 to obtain credits. For MY 2020 and beyond, auto

\footnotetext{
${ }^{26}$ Vehicle populations were determined using 2017 IHS Automotive (formerly Polk) vehicle registration data purchased by NREL.

${ }^{27}$ AFDC Light-Duty Vehicle Search allows users to identify alternative fuel vehicle availability by MY and manufacturer: http://www.afdc.energy.gov/vehicles/search.
} 
manufacturers will need to demonstrate that the vehicle is using E10+ fuels for credits. This requirement will be extremely difficult to meet as vehicles are not equipped with refueling data collection, and states generally track total ethanol sales (no differentiation between E10 and E85) for taxation purposes.

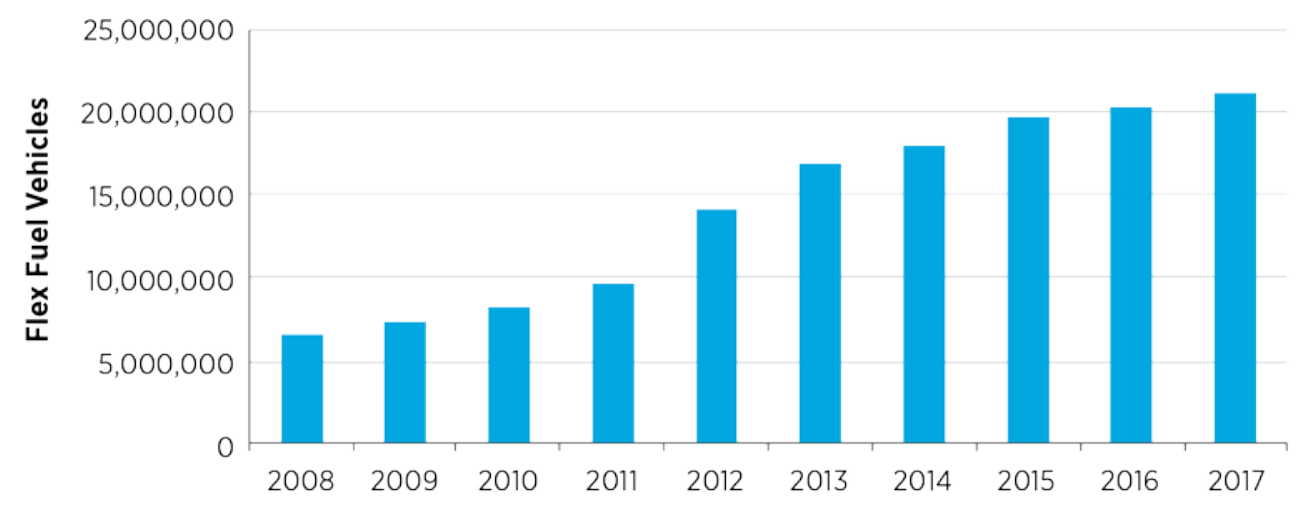

Figure 18. U.S. historical FFV stock

Source: IHS Automotive, https://www.ihs.com/btp/polk.html (data purchased annually)

\subsection{Biobutanol}

Biobutanol is a four-carbon alcohol (butyl alcohol) produced from the same feedstocks as ethanol, including corn grain and other biomass. While there are four isomers of butanol, the most active commercialization work centers around isobutanol for blending with gasoline. There are two Clean Air Act provisions that allow for blending of up to $12.5 \%$ biobutanol with gasoline. Additionally, under the Octamix waiver, for which human health effects testing is ongoing, a 16\% biobutanol blend is a legal fuel equivalent to E10 (EPA 2012). Biobutanol has an ASTM D7862 fuel quality standard for blends up to $12.5 \%$ with gasoline. It is important to ensure that biobutanol blended with ethanol-gasoline combinations does not result in an oxygen content exceeding the EPA limit of 3.7\%. The benefits of biobutanol when compared with ethanol are that biobutanol is less miscible with water and has a higher energy content and lower Reid vapor pressure. Under the RFS, corn grain butanol meets the renewable fuel $20 \%$ GHGemission reduction threshold (EPA 2010; EPA 2018b).

One challenge for biobutanol is that more ethanol, on a volume basis, can be produced from a bushel of corn than biobutanol (Ramey 2007). Biobutanol companies produce transportation fuel and a range of high-value products with a goal of improving economic performance through diversification of product offerings. Primary coproducts of biobutanol plants may include solvents/coatings, plastics, and fibers. Two companies pursuing biobutanol are Gevo and Butamax. Both companies have focused on retrofitting existing corn plants to demonstrate their technologies. Both companies have received EPA approval for fuels registration with the maximum allowable content of $16 \%$.

The near-term outlook for biobutanol production is limited, as production has been small and intermittent since 2012. Approximately 12,000 gallons entered the commercial market in 2013, none in 2014 and 2015, more than 125,000 gallons in 2016, and none in 2017 (EPA 2018a). A 
retail chain in the Houston area began sales of a 12.5\% isobutanol blend in 2016 (Voegele 2016). Gevo began producing cellulosic biobutanol that is converted to jet fuel, meeting fuel quality specification D7566 for use by commercial airlines (Voegele 2016).

Oak Ridge National Laboratory researched the compatibility of refueling equipment materials with biobutanol and has found that equipment compatible with ethanol blends would also be compatible with biobutanol. UL announced in late 2013 that equipment certified under testing subject 87A (for blends above E10) could also retain certification if used with biobutanol blends up to $16 \%$. It is anticipated that biobutanol would be distributed by tanker truck and rail, with the potential for transportation in pipelines following research demonstrating its safety. Biobutanol is compatible with existing vehicles at blends of $16 \%$ or less with gasoline, and it provides the same fuel economy as E10 (Butamax 2016).

\subsection{Biodiesel}

\subsubsection{Biodiesel Overview}

Biodiesel is an alternative fuel manufactured from multiple feedstocks - including vegetable oils, animal fats, or yellow grease-for use in diesel vehicles. It is referred to as biomass-based diesel in the RFS, along with renewable diesel, which is a different alternative fuel described in Section 2.4. Biodiesel is produced by transesterification - a process that converts fats and oils into biodiesel and glycerin (a coproduct). Biodiesel's physical properties are similar to those of petroleum diesel, and they can be blended in any combination. Any blends of B5 (5\% biodiesel, 95\% petroleum diesel) or below meet ASTM fuel quality specification D975 for conventional diesel fuel and can be used in existing infrastructure and any compression-ignition engine intended for petroleum diesel. ASTM specification D7467 describes the properties of B6 to B20 blends. B20 is the most common higher-level biodiesel blend, and engines operating on B20 have similar fuel consumption, horsepower, and torque to engines running on petroleum diesel. Some, but not all, engine and diesel vehicle manufacturer warranties cover the use of B20. Pure biodiesel (B100, ASTM specification D6751) is typically used for blending with petroleum diesel and is rarely used in engines due to higher costs, cold weather performance issues, and lack of compatibility with vehicles and infrastructure. In the first years of biodiesel production, fuel quality was an issue. Industry worked with ASTM to establish fuel quality standards and a voluntary quality assurance program known as BQ9000 to support higher-quality fuels in the market. Biodiesel is distributed by truck, train, and barge. While uncommon, biodiesel can be moved in pipelines; however, there are restrictions to consider if the pipeline also carries jet fuel.

The market for biodiesel is relatively small but has been growing over the past 5 years-it currently accounts for approximately $3.2 \%$ of the nearly 62-billion-gallon annual diesel market (EIA 2018a; EIA 2018g). ${ }^{28}$ Biodiesel demand is driven primarily by the RFS under two subcategories in the advanced biofuels requirements-biomass-based diesel and other advanced biofuels. The first year that biodiesel production and consumption exceeded the RFS requirement for biomass-based diesel was 2013, and excess production was used to meet the overall advanced biofuel requirement of the RFS. Several states also have biodiesel mandates. B5 has long been

\footnotetext{
${ }^{28}$ The diesel market of 59 billion gallons refers to No. 2 Distillate, which includes both fuel oil and diesel fuel-the two markets where biodiesel is used.
} 
approved for use in home heating oil, and there is an opportunity for growth in this market, with ASTM releasing a B20 home heating oil fuel quality specification in 2015.

Under the RFS, biodiesel generally meets the biomass-based diesel 50\% GHG-emissions reduction threshold, and it is currently the main contributor to this fuel category (EPA 2010; EPA 2018a; EPA 2018b). Use of biodiesel in older on-highway diesel engines also reduces emissions of unburned hydrocarbons, carbon monoxide, sulfates, polycyclic aromatic hydrocarbons, nitrated polycyclic aromatic hydrocarbons, and particulate matter. For 2010 and newer MY diesel engines, tailpipe emissions are controlled using catalysts and filters such that fuel composition has little effect on emissions. Biodiesel prices are directly correlated with petroleum diesel prices (Figure 19).

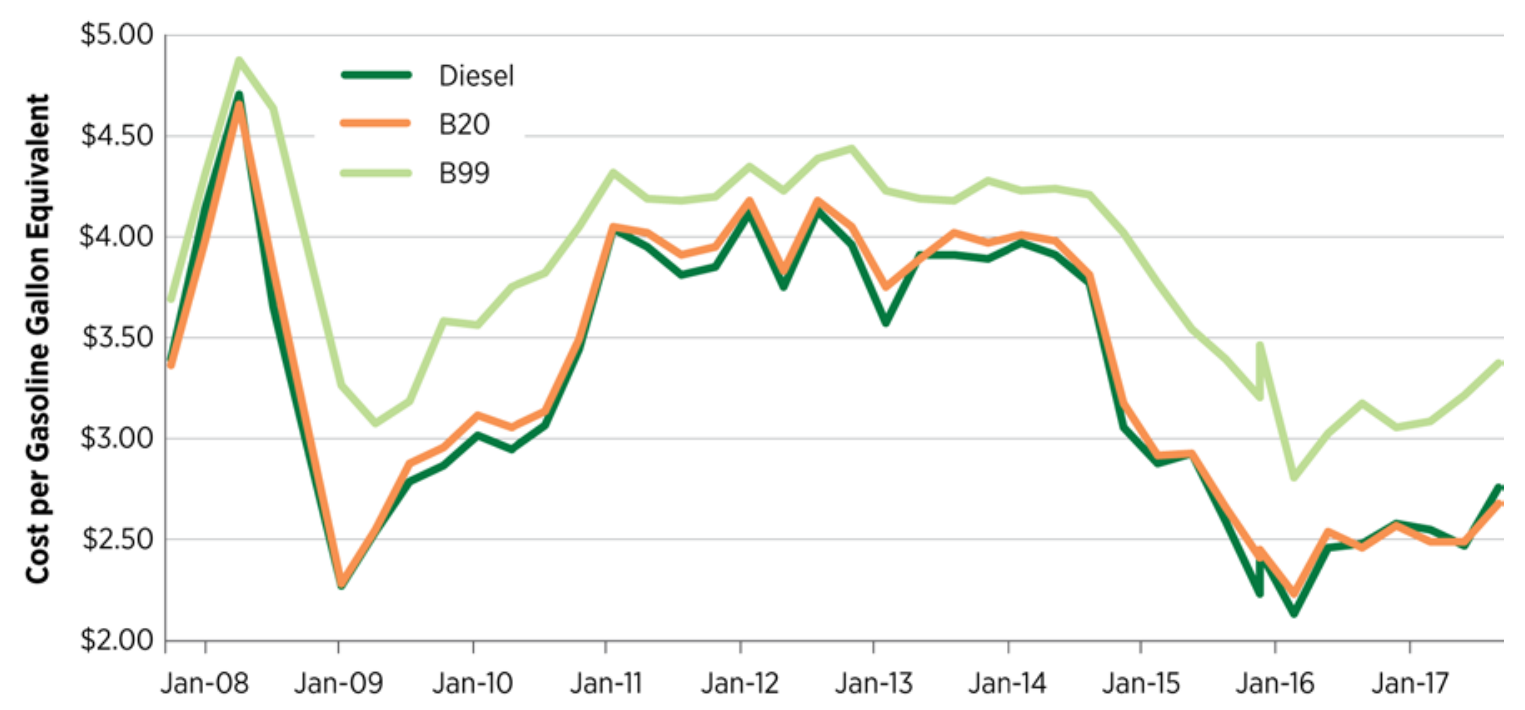

Figure 19. U.S. retail biodiesel prices

Source: DOE 2018

Research and development on biodiesel production has primarily focused on improved separation processes for product cleanup and the development of inorganic heterogeneous (solid) and enzyme catalysts for the transesterification reaction. The majority of research on separation processes is proprietary and has been conducted by the biodiesel manufacturers; this research has resulted in incremental improvements in the efficiency of their processes. Research on heterogeneous and enzyme catalysts has been published in the public domain, but none of these technologies have been adopted by biodiesel producers.

A major area of research sponsored by the biodiesel industry over time has been the performance of biodiesel blends in the fuel distribution system and in engines. This research has led to significant changes to the ASTM specifications for B100 and biodiesel blends that improved storage stability and cold-weather operation.

\subsubsection{Feedstocks}

Biodiesel in the United States is produced from various lipid feedstocks, such as vegetable oils, animal fats, and waste greases. About $50 \%$ of the biodiesel plants do not rely on one type of feedstock and use multiple sources to ensure optimal feedstock supply security. 
Soybean oil is the most common biodiesel feedstock, providing more than $52 \%$ of the total input (Figure 20). Over 6.2 billion pounds of soybean oil were used for biodiesel production in 2017, which is about $26 \%$ of the soybean oil produced that year (EIA 2018h; USDA-ERS 2018b).

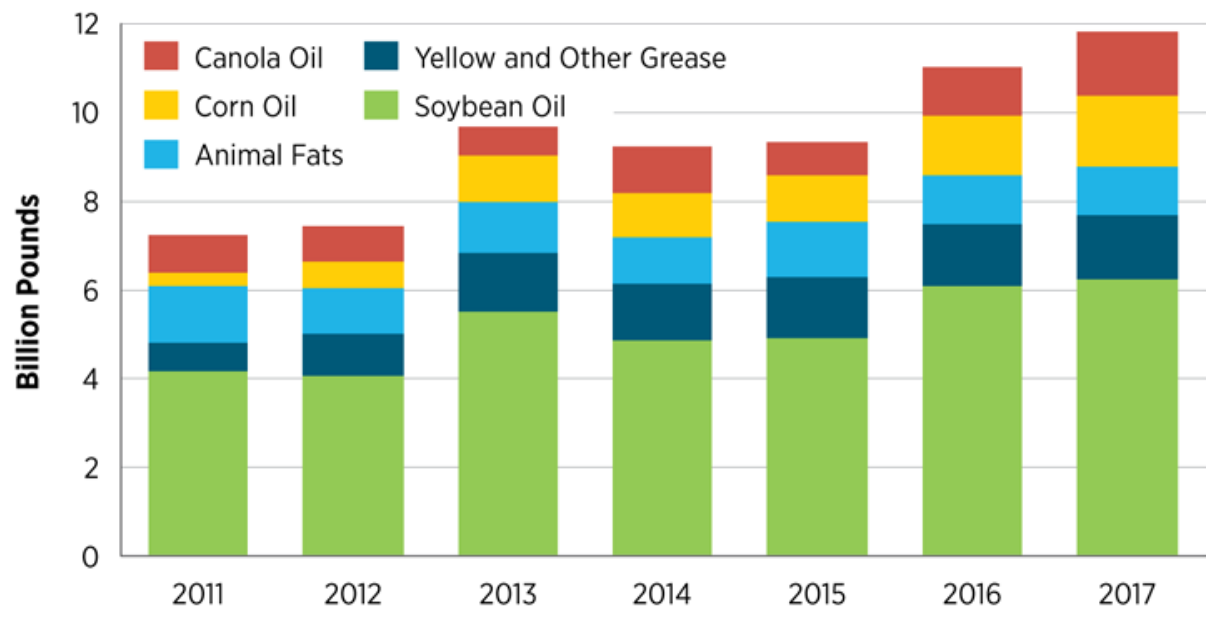

Figure 20. U.S. inputs to biodiesel production

Source: EIA 2018h

Nearly 1.5 billion pounds of canola oil and 1.6 billion pounds of corn oil were used for biodiesel production in 2017 (Figure 20). In the past, corn oil had not been used as a feedstock; however, the production of low-cost, nonfood-grade-quality corn oil by ethanol plants has resulted in a substantial increase in corn oil use for biodiesel over the past 5 years. ${ }^{29}$

The use of yellow grease (filtered, used cooking oil) for biodiesel production almost doubled in 2013 due to low cost and resource availability, and has remained at the same level through 2017. Consumption of yellow grease for biodiesel production was about 471 million pounds in 2011 and reached almost 1.5 billion pounds in 2017, making it one of the main feedstock sources for biodiesel production. Animal fats provided about $9 \%$ of the total biodiesel feedstock supply in 2017, or about 1.1 billion pounds (EIA 2018h).

\subsubsection{Historical Production, Consumption, and Capacity}

Both biodiesel production and consumption have expanded over the past decade, reaching a total production of 1.59 billion gallons in 2017 (EIA 2018a); however, there have been interesting market dynamics (Figure 21). Between 2007 and 2009, production exceeded domestic consumption, and exports to European nations were common due to higher prices, but that opportunity declined in 2010 due to European Union legislation. Fuel companies were taking advantage of the U.S. production tax credit and exporting lower-cost biodiesel, prompting the European Union to issue a protectionist policy. This, likely combined with uncertainty about renewal of the federal biodiesel production tax credit, led to a period of lower production. EPA finalized RFS volume requirements for 2014 through 2017 in November 2016, which guarantees

\footnotetext{
${ }^{29}$ Corn oil is a coproduct at ethanol plants and does not impact the quantity of ethanol production.
} 
a market for biodiesel with an increase each year. ${ }^{30}$ From 2013 through 2017, biodiesel consumption exceeded production due to biodiesel imports.

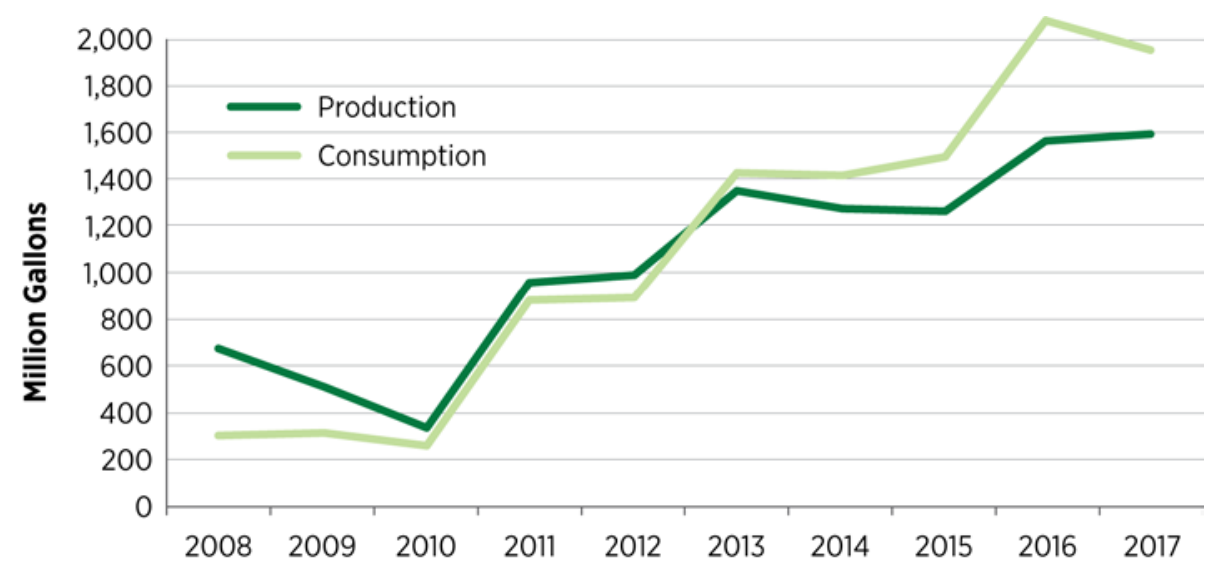

Figure 21. U.S. biodiesel production and consumption

Source: EIA 2018a, Table 10.4

As of December 2017, there were 95 biodiesel plants with a total industry production capacity of nearly 2.4 billion gallons in 36 states (Figure 22) (EIA 2018h). Biodiesel plant capacity ranges from less than 1 million gallons to up to 180 million gallons. The average biodiesel plant size is about 24 million gallons (EIA 2018h). In terms of production capacity, the largest biodiesel producer is Renewable Energy Group, which operates 10 plants with a total production capacity of 365 million annual gallons (Biodiesel Magazine 2017). Other large producers include traditional agricultural commodity processers and oleochemical producers: Ag Processing (150million-gallon capacity), ADM (85-million-gallon capacity), and Louis Dreyfus (90-milliongallon capacity). Several companies focused exclusively on biodiesel production also have significant production capacity, including RBF Port Neches, which is the largest-capacity plant in North America at 180 million gallons.

\footnotetext{
${ }^{30}$ See RFS final volumes: https://www.epa.gov/newsreleases/epa-finalizes-rfs-volumes-2018-and-biomass-baseddiesel-volumes-2019.
} 


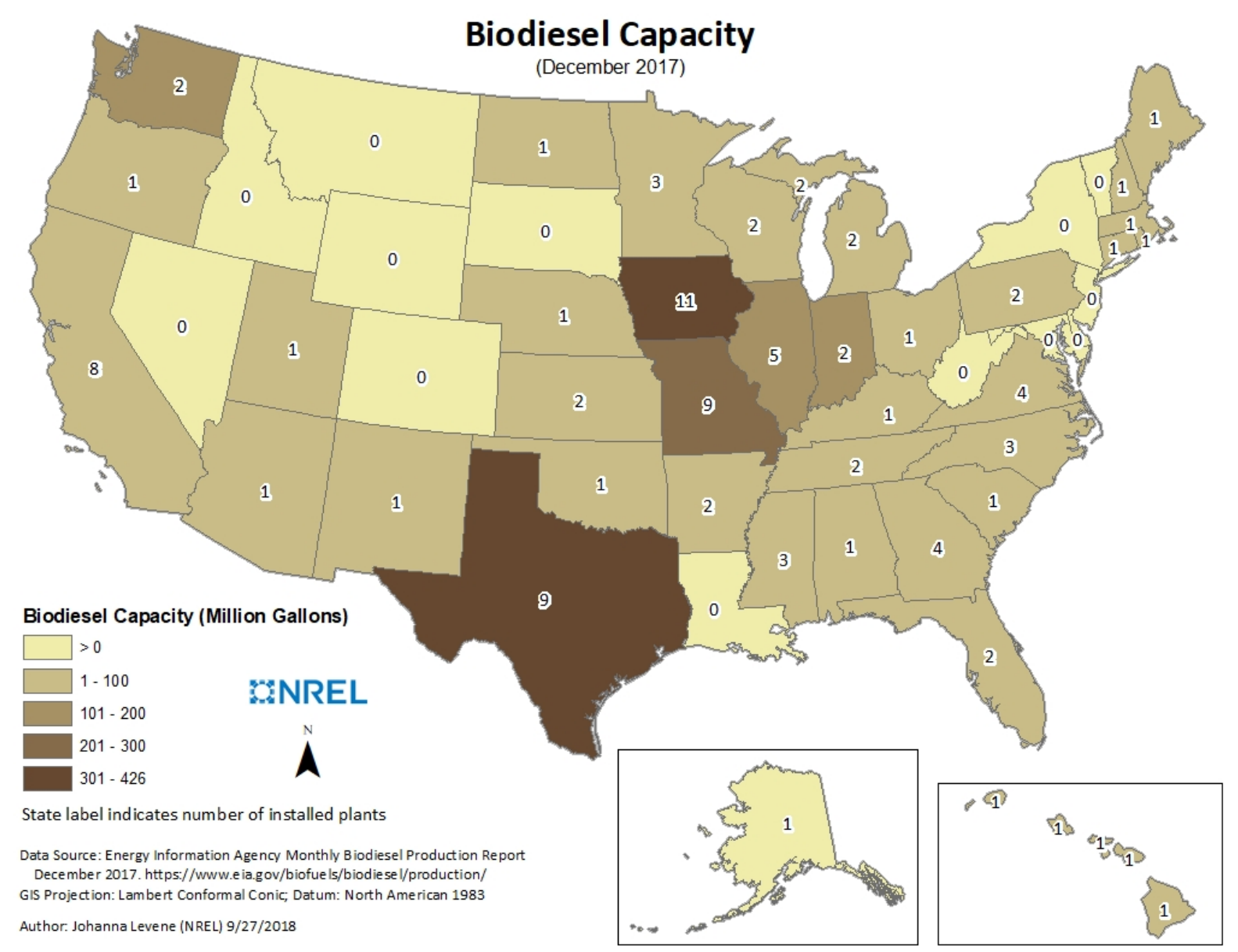

Figure 22. Biodiesel plants by state (as of December 2017)

Source: EIA 2018h, Table 4

As shown in Figure 23, biodiesel plants operate below capacity, but utilization of capacity has increased since 2012. The reason plants are idle or closed is typically related to economic conditions, where costs exceed market prices or periods when the federal biodiesel producer tax credit was unavailable. It has been challenging for biodiesel plants to remain profitable without the producer tax credit. Insufficient cash flow and limited or no access to credit also affect plants' ability to operate. Newer or upgraded plants may have greater efficiencies and the ability to use multiple feedstocks, which allows them the flexibility to use the most cost-effective feedstocks over time. 


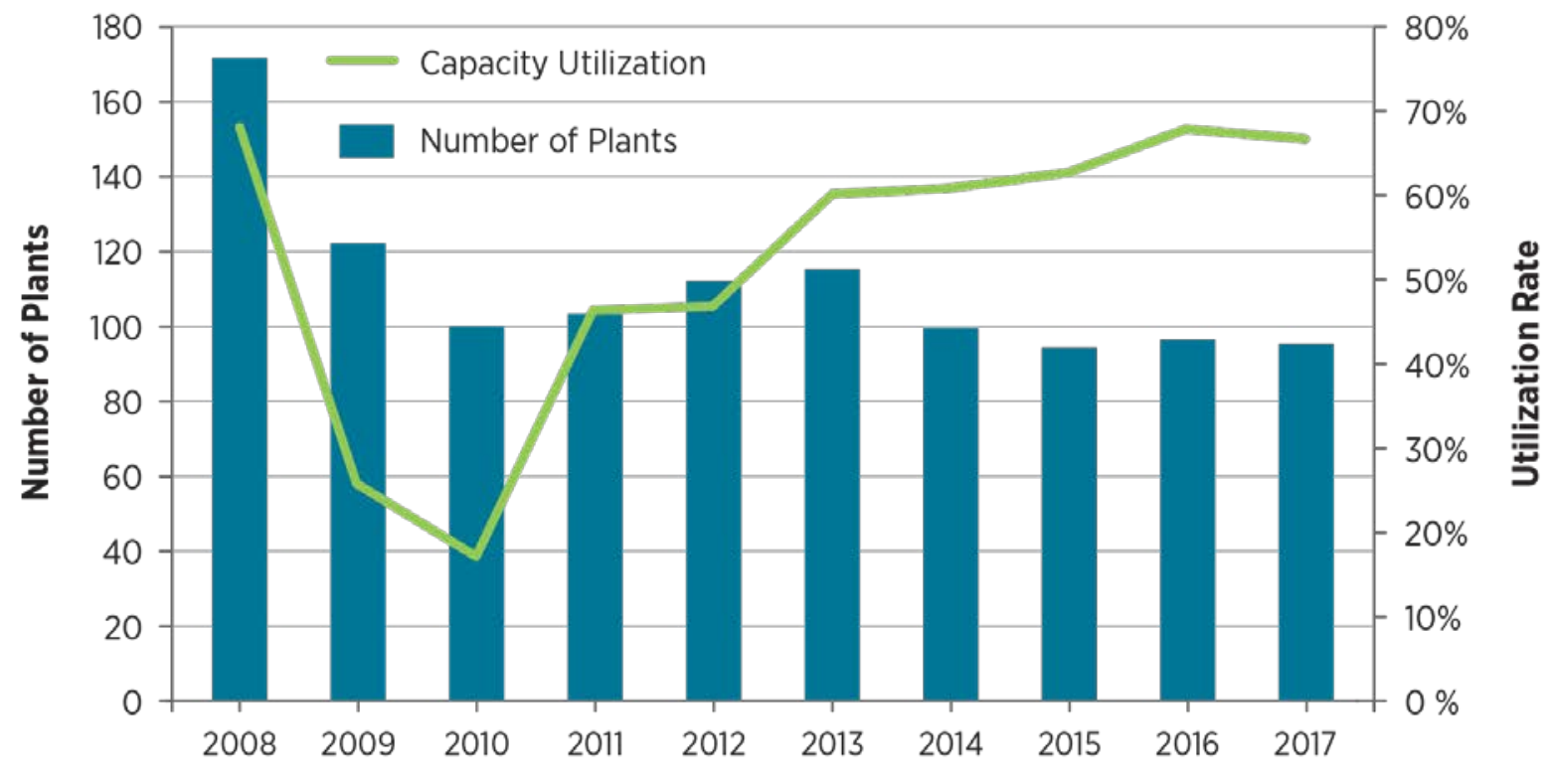

Figure 23. U.S. historical biodiesel plant capacity

Source: EIA 2018f, Table 4. Biodiesel producers and production capacity by state supplemented with data from National Biodiesel Board for years 2006-2008 and 2010. Capacity utilization is production divided by installed capacity from EIA 2018a, Table 10.4 .

\subsubsection{Production Cost}

Biodiesel production costs vary based on the feedstock being used; plant size, type, and design; when the plant was built; and how the plant is managed. Iowa State University developed a model to track Iowa's biodiesel profit margins and production costs over time based on Iowa's biodiesel prices and costs for soybean oil and methanol, as well as other operating costs (Hofstrand 2018b). Over the past 9 years, soybean oil has accounted for $81 \%$ of operating costs at an average Iowa biodiesel plant, with lower costs for methanol and other operating costs. Production costs varied between $\$ 2.63$ and $\$ 5.41$ per gallon between January 2008 and December 2017 (Figure 24). Biodiesel plants using other feedstocks, such as corn oil, canola oil, tallow, and waste grease, would experience different costs; however, feedstock costs typically comprise $70 \%-95 \%$ of overall operation costs (Tao and Aden 2009). 


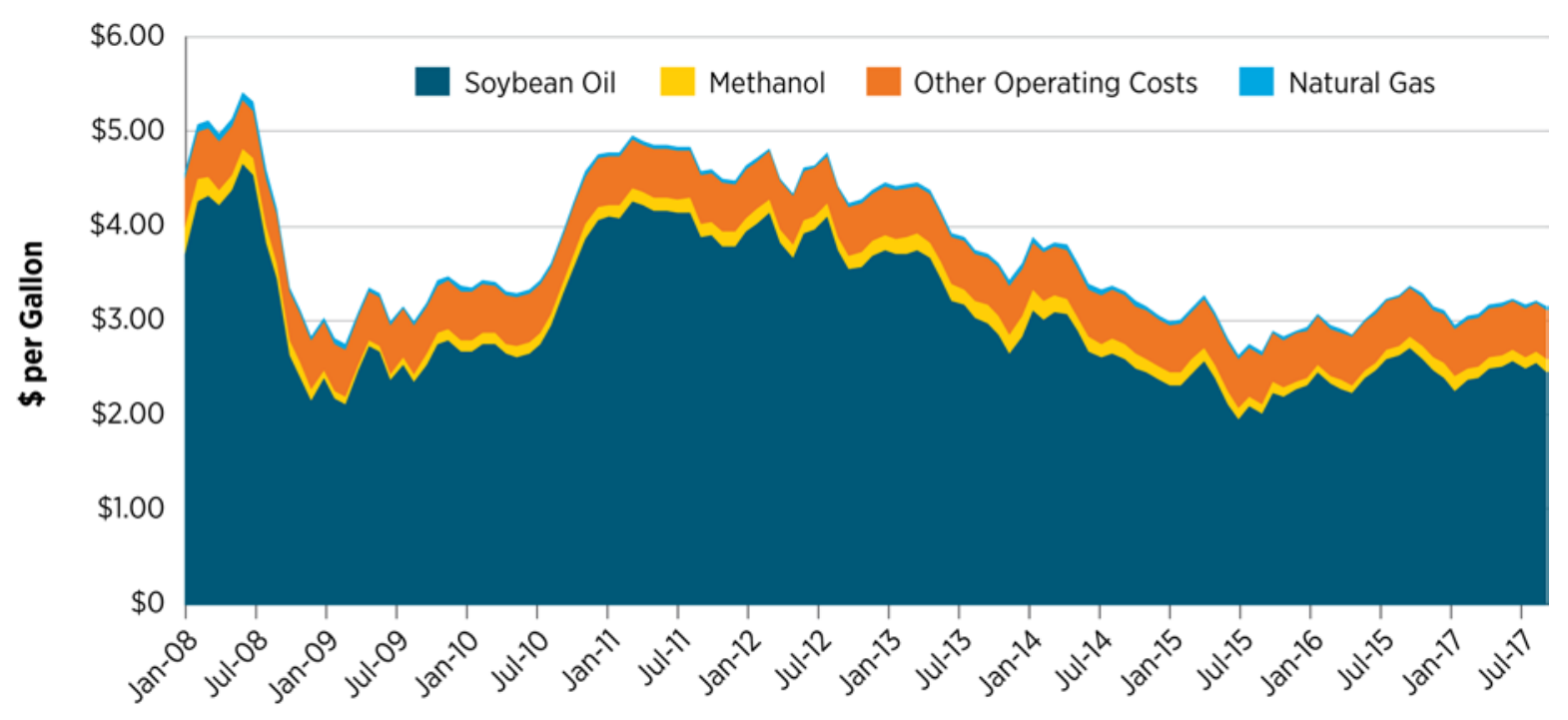

Figure 24. U.S. soybean-based biodiesel production cost trends

Source: Hofstrand 2018b

\subsubsection{Coproducts Overview}

The only coproduct of biodiesel production is glycerin, which is used in food, hygiene, and pharmaceutical products. Each gallon of biodiesel produced results in 1.05 pounds of glycerin. Biodiesel production has resulted in an oversupply of glycerin for U.S. markets, leading to low prices for crude glycerin, valued at $\$ 0.03$ per gallon of biodiesel produced, with higher prices for upgraded or refined glycerin (Hofstrand 2018b). Research is focused on other uses for glycerin with an emphasis in the areas of algae, syngas, and yeast production.

One of DOE's technology transfer successes is ADM's 100,000-metric-ton renewable propylene glycol plant. ADM converts glycerin from biodiesel production into propylene glycol. The renewable propylene glycol is a component of several USDA-certified green product lines, mostly heat transfer fluids (Biddy, Scarlata, and Kinchin 2016).

\subsubsection{Economic Impacts of Biodiesel}

A study conducted for the National Biodiesel Board indicated that under assumptions in 2015 of 1.43 billion gallons of U.S. production and 670 million gallons of imports, there would be a contribution of $\$ 8.4$ billion in economic activity and support of more than 47,400 direct jobs (NBB 2016). ${ }^{31}$

According to the same National Biodiesel Board study, from 2005 to 2013, biodiesel production in the United States increased from 209 million gallons (747,000 tons) to 1.13 billion gallons (just over 4 million tons). The gross impacts of this increased production include the following:

- The economic impact of biodiesel increased from $\$ 1.4$ billion annually in 2006 to $\$ 8.4$ billion in 2015.

\footnotetext{
312017 data are not available.
} 
- The number of direct jobs supported increased from just fewer than 7,000 in 2006 to more than 47,400 in $2015 .{ }^{32}$

- Wage impacts increased from $\$ 260$ million in 2005 to $\$ 1.9$ billion in 2015 , implying that the average job supported by the biodiesel sector paid a wage of approximately $\$ 39,300 /$ year in 2015 .

\subsubsection{Policies That Affect This Market}

Biodiesel has been primarily impacted by two policies - the RFS and the biodiesel tax credit. ${ }^{33}$ The biodiesel tax credit of $\$ 1.00 /$ gallon was originally established by the American Jobs Creation Act of 2004; it has expired and been retroactively reinstated four times through other legislation, expiring again at the end of 2016 and retroactively reinstated for 2017 in February 2018. The estimated cumulative federal investment for the biodiesel production tax credit since its inception is $\$ 9.8$ billion (Figure 25). ${ }^{34}$ The availability of the tax credit has influenced production - as production costs sometimes exceed the price paid for biodiesel (Figure 19 and Figure 24). Between 2005 and 2011, there was a small producer tax incentive of $\$ 0.10$ /gallon for the first 15 million gallons of biodiesel production at facilities using pure vegetable oils as feedstock with capacity of 60 million or fewer gallons per year. Additional federal investment in the biodiesel industry was allocated through grants, loan guarantees, and tax credits to assist retail and fleet stations in costs to upgrade equipment to accommodate B20.

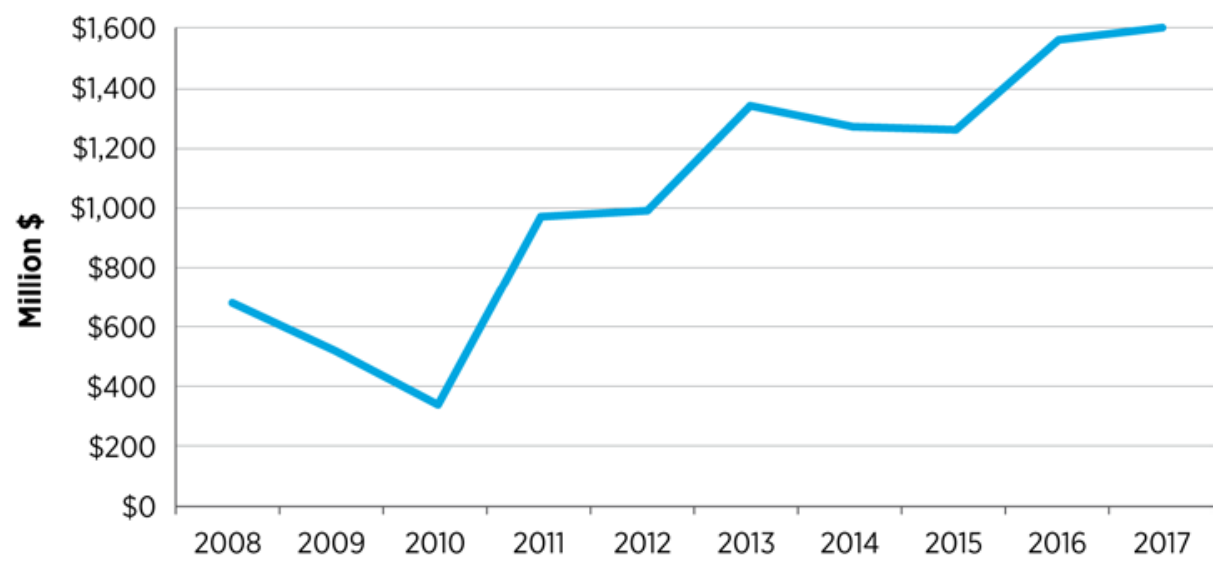

Figure 25. Estimated federal investment in the biodiesel tax credit

Sources: EIA 2018a, Table 10.4; AFDC 2018d. Calculated by multiplying biodiesel production by tax incentive of $\$ 1.00 /$ gallon.

\subsubsection{Biodiesel Trade}

U.S. biodiesel trade (Figure 26) dynamics are largely affected by policies. The U.S. Energy Information Administration (EIA) reports that imports grew significantly in 2016 and fell in 2017 because the United States imposed import duties on biodiesel from Argentina and

\footnotetext{
${ }^{32}$ The jobs estimated in Urbanchuk (2018) and NBB (2016) are different than job estimates in DOE's 2017 U.S. Energy and Employment Report because the latter relied on surveys, which can result in lower numbers.

${ }^{33}$ This section covers federal incentives and policies. States may also have incentives and policies. This information is available from the "Laws and Incentives" section of the AFDC website: http://www.afdc.energy.gov/laws.

${ }^{34}$ This calculation is based on multiplying production by $\$ 1.00 /$ gallon.
} 
Indonesia. Imports were from four nations; the majority came from Argentina (73\%) and Canada (21\%) (EIA 2018a). Imports from Argentina were driven by EPA's approval of an RFS pathway in January 2016, allowing producers in Argentina to generate RINs (Hill 2016). The United States exported to 14 nations in 2017, with Canada accounting for 86\% (EIA 2018f).

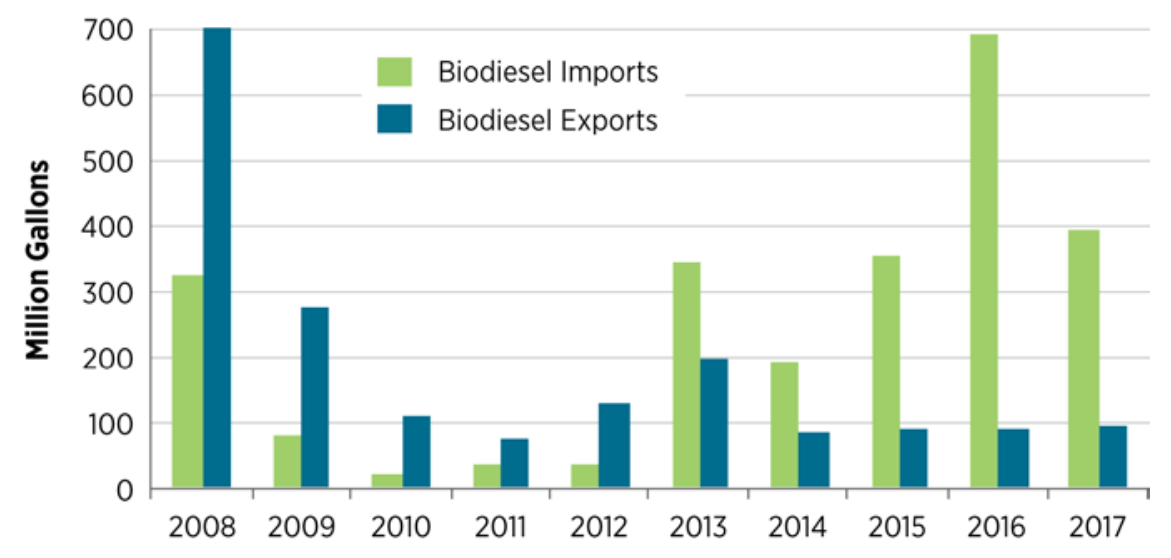

Figure 26. U.S. historical biodiesel imports and exports

Sources: EIA 2018e; EIA $2018 f$

\subsubsection{Infrastructure}

The same patchwork of infrastructure regulation that applies to ethanol blends of more than E10 also applies to biodiesel blends of more than B5 for aboveground equipment and of more than B20 for belowground equipment (refer to Section 2.1.13). Federal code allows storage of up to B20 in existing underground storage tank systems. All existing steel and fiberglass underground storage tank manufacturers have issued letters stating compatibility with B100; however, the decades-long usage of tanks means that there are tanks installed by manufacturers that are no longer in business, and these tanks cannot store blends above B20. ${ }^{35}$ UL-listed B20 aboveground equipment has been available since 2013 .

Diesel use is predominately related to the trucking industry's consumption pattern and not personal vehicles. This is why many retail stations offering diesel are located along major trucking routes. This is also the reason stations selling B20 are located primarily in urban centers and along major highways. Those outside of these locations are typically private stations serving the fleets of the U.S. Department of Defense, other federal agencies, and local governments. Of the 681 refueling stations offering B20, 198 are open to the public (Figure 27). There is a growth opportunity for biodiesel at some of the 2,500 truck stops across the nation because less than 20 of these truck stops sold B20 as of December $2017 .{ }^{36}$

\footnotetext{
${ }^{35}$ A list of biodiesel-compatible tanks, associated equipment, and UL-listed dispensers and hanging hardware is available on the AFDC website: http://www.afdc.energy.gov/fuels/biodiesel infrastructure.html.

${ }^{36}$ Based on NREL analysis of data from the AFDC Alternative Fueling Station Locator: http://www.afdc.energy.gov/locator/stations.
} 


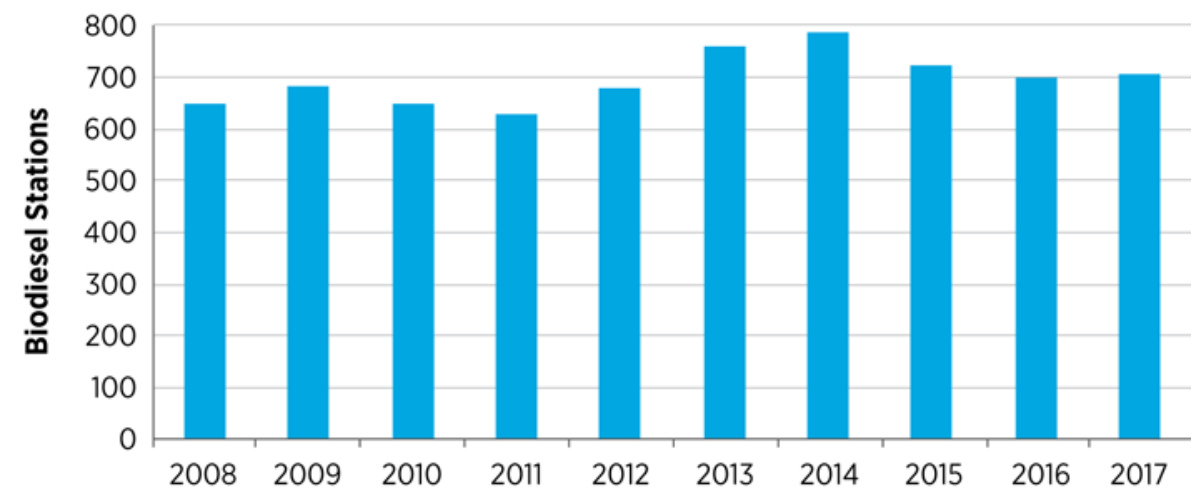

Figure 27. U.S. historical biodiesel (B20) refueling stations

Source: AFDC 2018c

\subsubsection{End Use}

Existing diesel vehicles can use B5 without any modifications to vehicles or infrastructure. There were 17 MY 2017 cars, pickup trucks, and vans approved by the manufacturer for use with B20 and at least 30 engines approved for B20 use in medium- and heavy-duty vehicles and trucks. The National Biodiesel Board provides information on biodiesel blend approvals for vehicles and engines for each MY. ${ }^{37}$ Biodiesel is also used in off-road applications such as farm equipment and in backup generators.

There is an opportunity to increase biodiesel use in the home heating oil market, which is concentrated in the Northeast. Biodiesel blended with home heating oil is marketed as Bioheat fuel by the National Oilheat Research Alliance (NORA). B5 can be used in standard home heating oil equipment, and a NORA survey of 35,000 buildings using B5 reported no issues (NORA 2014). Since 2008, ASTM D396 Standard Specification for Fuel Oils has allowed a blend of up to B5 in home heating oil. NORA research results on blending B20 with standard and low-sulfur home heating oil showed no impact on heating equipment. This led to ASTM approving the use of B6-B20 under ASTM D396 released in 2015.

\subsection{Renewable Hydrocarbon Biofuels}

Renewable hydrocarbon transportation fuels (also called "green" hydrocarbons, biohydrocarbons, drop-in biofuels, and sustainable or advanced hydrocarbon biofuels) are fuels produced from biomass sources through a variety of biological, thermal, and chemical processes. These products are similar to petroleum gasoline, diesel, or jet fuel in chemical makeup and, therefore, are considered fully infrastructure-compatible fuels. It is anticipated that these fuels can be used in vehicles without requiring engine modifications and can utilize existing petroleum fuel pipelines and retail distribution systems. This eliminates the infrastructure compatibility concerns associated with ethanol and biodiesel.

Renewable hydrocarbon biofuels are produced from various biomass sources. These include lipids (vegetable oils, animal fats, greases, and algae) and cellulosic material (e.g., crops, crop

\footnotetext{
${ }^{37}$ National Biodiesel Board original equipment manufacturer information: http://www.biodiesel.org/usingbiodiesel/oem-information.
} 
residues, woody biomass, and others). Several conversion processes are being explored for the production of renewable hydrocarbon biofuels:

- Traditional hydrotreating used in petroleum refineries, which involves reacting the feedstock (lipids) with hydrogen under elevated temperatures and pressures in the presence of a catalyst

- Biological sugar upgrading, which uses a biochemical deconstruction process similar to that used with cellulosic ethanol and then organisms that convert sugars to hydrocarbons

- Catalytic conversion of sugars, which involves a series of catalytic reactions to convert a carbohydrate stream into hydrocarbon fuels

- Gasification, in which biomass is thermally converted to syngas and catalytically converted to hydrocarbon fuels

- Pyrolysis, which involves the chemical decomposition of organic materials at elevated temperatures in the absence of oxygen to produce a liquid pyrolysis oil that can be upgraded to hydrocarbon fuels, either in a standalone process or as a feedstock for cofeeding with crude oil into a standard petroleum refinery

- Hydrothermal processing, which uses high pressure and moderate temperature for chemical decomposition of biomass or wet waste materials to produce an oil that may be catalytically upgraded to hydrocarbon fuels.

Renewable gasoline, also known as biogasoline or "green" gasoline is a collection of gasolineboiling-range hydrocarbons derived from biomass, suitable for use in spark-ignition engines and for meeting ASTM specification D4814 in the United States and EN 228 in Europe. Under the RFS, renewable gasoline from cellulosic feedstocks meets the cellulosic biofuel $60 \%$ GHGemission reduction threshold (EPA 2010; EPA 2018b).

Renewable diesel, also called "green" diesel, is a transportation fuel derived from biomass sources suitable for use in diesel engines that meets the ASTM D975 specification in the United States and EN 590 in Europe. Renewable diesel is distinct from biodiesel. While renewable diesel meets the same fuel property specifications as petroleum diesel in ASTM D975, biodiesel is a mono-alkyl ester, which has different physical properties and, therefore, different fuel specifications (ASTM D6751 and EN 14214). The two fuels are also produced through very different processes. While biodiesel is produced via transesterification, renewable diesel is produced through various processes, such as hydrotreating/isomerization, gasification, pyrolysis, and other thermochemical and biochemical means. Moreover, biodiesel is produced exclusively from lipids whereas renewable diesel is produced from lipids and cellulosic biomass. Under the RFS, renewable diesel from cellulosic feedstocks meets the cellulosic diesel $60 \%$ GHG-emission reduction threshold (EPA 2010; EPA 2018b). Under the RFS, renewable diesel from biomassbased oils meets the biomass-based diesel 50\% GHG-emission reduction threshold (EPA 2010; EPA 2018b). To be classified as a biomass-based diesel, renewable diesel production must not involve co-processed biomass-based oils with petroleum (EPA 2018b).

Sustainable aviation fuel, also known as renewable jet fuel, "biojet," or aviation biofuel, is a biomass-derived fuel that can be used interchangeably with petroleum-based aviation fuel. 
Currently, there are five synthetic paraffinic kerosene (SPK) and synthetic kerosene with aromatics (SKA) fuel categories approved by ASTM:

- Hydrogenated esters and fatty acids (HEFA) fuels derived from used cooking oil, animal fats, algae, and vegetable oils (e.g., camelina) (HEFA-SPK)

- Fischer-Tropsch (FT) fuels using solid biomass resources (e.g., wood residues) (FT-SPK)

- $\quad$ FT fuels with aromatics using solid biomass resources (e.g., wood residues) (FT-SKA)

- Synthetic isoparaffin (SIP) from fermented hydroprocessed sugar, formerly known as direct-sugar-to-hydrocarbon fuels; blends of up to $10 \%$ are permitted for this fuel (SIPSPK)

- Alcohol-to-jet (ATJ) fuels produced from isobutanol and blended to a maximum level of $30 \%$ (ATJ-SPK).

SPK fuels have to be blended up to $50 \%$ with conventional commercial and military jet (or aviation turbine) fuel, while SKA fuels have the potential to replace fossil fuels. Blending of SPK fuels is required because they lack sufficient aromatic hydrocarbons, which are present in conventional jet fuel. While aromatic hydrocarbons are limited in jet fuel to prevent smoke formation during combustion, a minimum aromatic content is needed to cause elastomer swell in aircraft fuel systems and increase fuel density.

Other processes in development with pending certification include aqueous phase reforming, a process that uses sugars as feedstock, and catalytic hydrothermolysis jet, a process that uses lipid feedstocks.

Since 2008, several airlines (e.g., Lufthansa, KLM, United, Alaska Airlines, and others) and aircraft manufacturers (e.g., Boeing and Airbus) performed flight tests with various blends containing up to $50 \%$ of the approved forms of SPK biojet fuel, namely HEFA-SPK and FTSPK. Additionally, flight tests were performed by military aircrafts of the U.S. Navy and U.S. Air Force.

\subsubsection{Commercialization of Renewable Hydrocarbon Biofuels}

Renewable diesel is a commercial fuel, and both production and consumption are increasing. EIA does not report renewable diesel production and consumption data; however, EPA collects RIN data for the RFS. Figure 28 shows volumes reported by EPA for renewable diesel, which totaled 588 million in 2017 (EPA 2018a). In the past, renewable diesel was imported from Singapore; however, domestic production has grown, with EPA reporting 258 gallons of domestic volumes under the RFS in 2017 (EPA 2018a). This fuel is used predominately by fleets in California. 


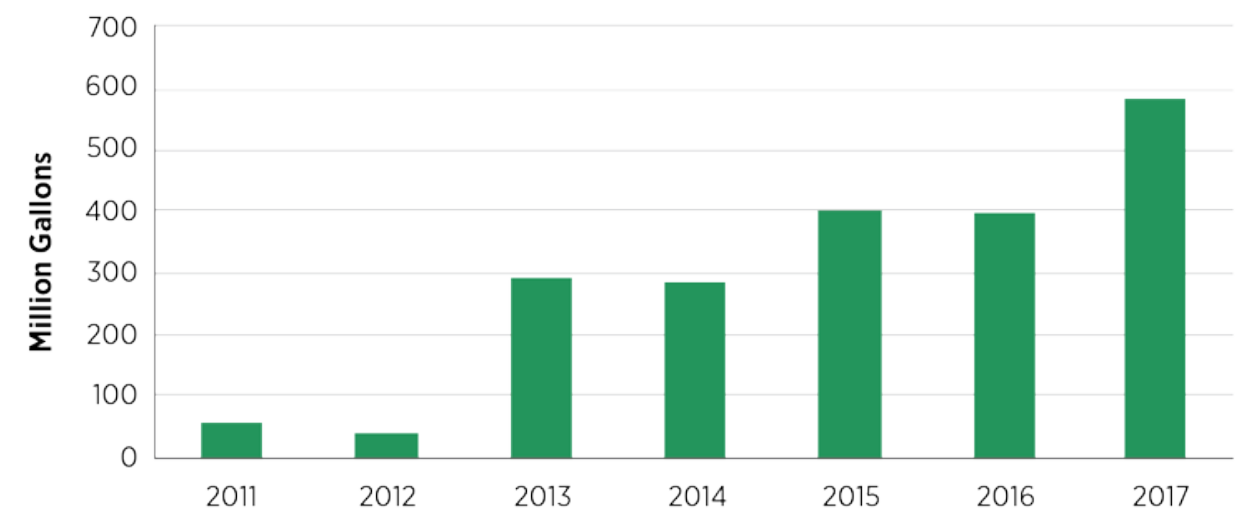

Figure 28. Estimated renewable diesel consumption

Source: EPA 2018a

Table 4 summarizes the commercial-scale renewable hydrocarbon projects operating and under construction. ${ }^{38}$ All of the operational plants are producing renewable diesel, while the World Energy plant is also producing sustainable aviation fuel. The under-construction Ryze Renewable plants plan to produce renewable diesel, while the Fulcrum plant plans to produce both renewable diesel and sustainable aviation fuel.

Table 4. Status of Commercial U.S. Renewable Hydrocarbon Projects in 2017

\begin{tabular}{|c|c|c|c|c|}
\hline Project Name & Location & $\begin{array}{c}\text { Capacity } \\
\text { (million gallons) }\end{array}$ & \multicolumn{2}{|c|}{ Feedstock } \\
\hline Cetane Energy & Carlsbad, NM & OPERATIONAL & fats, oils, greases & fats, oils, greases \\
\hline Diamond Green Diesel & Norco, LA & 3 & fats, oils, greases & oil catalytic \\
\hline East Kansas Agri-Energy & Garnett, KS & 275 & fats, oils, greases & oil catalytic \\
\hline Renewable Energy Group & Geismar, LA & 3 & fats, oils, greases & oil catalytic \\
\hline World Energy & Los Angeles, CA & 45 & municipal solid waste & fats, oils, greases \\
\hline Fulcrum BioEnergy & Reno, NV & UNDER CONSTRUCTION & syngas catalytic \\
\hline Ryze Renewables & Reno, NV; Las Vegas, & 10.5 & 168 & fil catalytic \\
\hline
\end{tabular}

Sources: Warner, Schwab, and Bacovsky 2017; International Energy Agency advanced biofuel plant list (provided to NREL); industry contacts; and media reports

Commercial-scale projects producing renewable hydrocarbons include:

- Operating (5): The total reported installed capacity is 398 MMGY. World Energy (formerly AltAir Fuels) retrofitted an existing petroleum refinery in 2014 in California for a 42-MMGY facility to primarily produce jet fuel and began operating in late 2015 (Lane 2016). Diamond Green Diesel expanded their facility to a total capacity of 275 MMGY with plans to expand their facility by another 400 MMGY (Diamond Green Diesel 2018). Renewable Energy Group, the largest producer of biodiesel, operates a 75MMGY plant. Cetane Energy retrofitted an existing biodiesel refinery in 2009 in

\footnotetext{
${ }^{38}$ The plants listed in Table 4 represent plants listed at the time that this report was prepared.
} 
Louisiana for a 3-MMGY facility to primarily produce diesel fuel and began operating in 2010 (Cetane Energy 2017). East Kansas Agri-Energy added technology at their existing ethanol plant to produce renewable diesel.

- Under Construction (2): Fulcrum BioEnergy began construction on their 10.5-MMGY facility in Reno, Nevada (Green Car Congress 2018). Ryze Renewables entered into a partnership with Phillips 66 to produce renewable diesel at two plants in Nevada with an expected combined capacity of 168 MMGY.

Table 5 summarizes demonstration- and pilot-scale renewable hydrocarbon projects. ${ }^{39}$

Table 5. Status of Precommercial U.S. Renewable Hydrocarbon Projects

\begin{tabular}{|c|c|c|c|c|}
\hline Project Name & Location & Feedstock & Deconstruction Technology & Upgrade Technology \\
\hline Amyris & Emeryville, CA & cellulosic sugars & & fermentation \\
\hline Anellotech & Silsbee, TX & woody biomass & pyrolysis & oil catalytic \\
\hline ARA & Panama City, FL & fats, oils, greases & & oil catalytic \\
\hline Frontline BioEnergy & Pasadena, TX & municipal solid waste & gasification & syngas catalytic \\
\hline Fulcrum BioEnergy & Reno, NV & municipal solid waste & gasification & syngas catalytic \\
\hline $\begin{array}{l}\text { Mainstream Engineering } \\
\text { Corporation }\end{array}$ & Rockledge, FL & municipal solid waste & hydrothermal liquefaction & oil catalytic \\
\hline Mississippi State University & Starkville, MS & woody biomass & hydrothermal liquefaction & oil catalytic \\
\hline NREL & Golden, $\mathrm{CO}$ & woody biomass & gasification & syngas catalytic \\
\hline NREL & Golden, $\mathrm{CO}$ & woody biomass & pyrolysis & oil catalytic \\
\hline $\begin{array}{c}\text { Pacific Northwest National } \\
\text { Laboratory }\end{array}$ & Richland, WA & woody biomass & hydrothermal liquefaction & oil catalytic \\
\hline $\begin{array}{l}\text { Pacific Northwest National } \\
\text { Laboratory }\end{array}$ & Richland, WA & woody biomass & pyrolysis & oil catalytic \\
\hline Renewable Energy Group & Okeechobee, FL & cellulosic sugars & & fermentation \\
\hline $\begin{array}{l}\text { Research Triangle Institute } \\
\text { International }\end{array}$ & Durham, NC & woody biomass & pyrolysis & oil catalytic \\
\hline $\begin{array}{l}\text { ThermoChem Recovery } \\
\text { International }\end{array}$ & Durham, NC & woody biomass & gasification & syngas catalytic \\
\hline Virent & Madison, WI & cellulosic sugars & & catalytic \\
\hline
\end{tabular}

Sources: Warner, Schwab, and Bacovsky 2017; International Energy Agency advanced biofuel plant list (provided to NREL); industry contacts; and media reports

\subsubsection{Production Costs}

Four emerging indirect liquefaction pathways were compared to a conventional FT pathway to produce gasoline-, jet-, and diesel-range hydrocarbon blendstocks from wood chips. The results of the comparison indicate that minimum fuel selling price (MFSP) ranges from $\$ 3.40$ to $\$ 5.04 /$ gge in 2011 dollars for all technology pathways, including the conventional FT pathway (Tan et al. 2016). Because the technology is not fully commercialized, the techno-economic analysis results reported here have not been harmonized; therefore, different assumptions, such as feedstock price and facility scale, contribute to variability. Additionally, there is variation between the assumed state of development, and these numbers range between current production price through future target scenarios.

\footnotetext{
${ }^{39}$ The plants listed in Table 5 represent plants listed at the time that this report was prepared.
} 
- The MFSP for the conventional FT pathway was $\$ 3.58$ /gge for a balanced mix of gasoline, renewable diesel, and jet fuel.

- Converting syngas to alcohols using a molybdenum disulfide $\left(\mathrm{MoS}_{2}\right)$ catalyst, followed by conversion of alcohols to a balanced mix of renewable diesel and jet fuel via alcohol condensation (Guebert reaction), dehydration, oligomerization, and hydrogenation resulted in an MFSP of $\$ 4.89 /$ gge.

- Syngas fermentations to ethanol, followed by conversion of alcohols to a balanced mix of renewable diesel and jet fuel via alcohol condensation (Guebert reaction), dehydration, oligomerization, and hydrogenation resulted in an MFSP of \$3.40/gge.

- Converting syngas to mixed oxygenates using a rhodium $(\mathrm{Rh})$ catalyst, followed by fuel production via carbon coupling/deoxygenation (to isobutene), oligomerization, and hydrogenation resulted in an MFSP of $\$ 3.69 /$ gge. The majority of fuel product is jet fuel.

- Syngas fermentation to ethanol, followed by fuel production via carbon coupling/deoxygenation (to isobutene), oligomerization, and hydrogenation resulted in an MFSP of $\$ 5.04 /$ gge. The majority of fuel product is jet fuel.

Bio-derived jet fuel can be classified into four broad technology pathways: ATJ, oil-to-jet (or HEFA), gas-to-jet (or FT), and sugar-to-jet.

- Isobutanol-to-jet and the ATJ technology pathways have been commercially demonstrated by Gevo and received ASTM D7566 certification in April 2016 (Gevo 2017). Cost estimates for isobutanol-to-jet fuel using wood chips as feedstock range from $\$ 4.80$ to $\$ 6.00 /$ gge in 2011 dollars, depending on facility scale (Wang et al. 2016).

- The use of HEFA fuels has been demonstrated in military jet flights. Cost estimates range from $\$ 2.40$ to $\$ 8.90 /$ gge in 2011 dollars, depending on the feedstock choice (Wang et al. 2016).

- FT biomass-to-liquids, a gas-to-jet technology pathway, has been commercially demonstrated by Syntroleum (later acquired by Renewable Energy Group) when blended 50/50 with Jet Propellant-8 (Syntroleum 2007). Cost estimates for FT biomass-to-liquids are between $\$ 3.10$ and $\$ 6.20 /$ gge in 2011 dollars when using wood chips as feedstock (Wang et al. 2016).

- Biological conversion of sugars-to-jet through fatty acid and farnesene intermediates has been successfully demonstrated by Amyris (Amyris 2013). Cost estimates for fuel production range from $\$ 4.30$ to $\$ 23.30 /$ gge in 2011 dollars, depending on feedstock choice (Wang et al. 2016).

\subsection{Renewable Natural Gas}

RNG, or biomethane, is a pipeline-quality gas that is interchangeable with conventional natural gas and thus can be used in natural gas vehicles. RNG is essentially biogas (the gaseous product of the decomposition of organic matter, composed primarily of methane, carbon dioxide, and other trace compounds) that has been processed to purity standards. Like conventional natural gas, RNG can be used as a transportation fuel in the form of compressed natural gas or liquefied natural gas. RNG meets the $60 \%$ GHG-emission reduction threshold to qualify as a cellulosic 
biofuel under the RFS and is currently the main contributor to this fuel category (cellulosic ethanol provides a minor input) (EPA 2018b).

Biogas is produced from various biomass sources through a biochemical process, such as anaerobic digestion $(\mathrm{AD})$, or through thermochemical means, such as gasification. Currently, most biogas in the United States is produced via $\mathrm{AD}$ of organic landfill waste, wastewater sludge, animal manure, and food waste (American Biogas Council 2016). With minor cleanup (e.g., siloxane removal), biogas is used to generate electricity and heat. To fuel vehicles, biogas must be processed to a higher purity standard. This process is called conditioning or upgrading and involves the removal of water, carbon dioxide, hydrogen sulfide, and other trace elements. The resulting RNG has a higher content of methane than raw biogas, which makes it comparable to conventional natural gas and thus a suitable energy source in applications that require pipeline-quality gas.

EPA reports nearly 159 million RINs or ethanol gallon equivalent of compressed RNG and about 83 million RINs or ethanol gallon equivalent of liquefied RNG were produced in 2017 under the RFS2 program (EPA 2018a). Figure 29 shows the increase in RNG production over the past 7 years due to a combination of more production facilities coming online and increased production at existing plants. The combined volume corresponds to about 161 million gge, or roughly 18.7 TBtu. The overall RNG potential in the United States is much larger and underutilized. NREL estimates that the RNG potential from landfills, animal manure, wastewater, and food waste (industrial, institutional, and commercial organic waste) in the United States is about 8.7 million tons per year, equivalent to 431 TBtu (NREL 2013). Thus, only $4.3 \%$ of the estimated RNG potential is currently utilized.

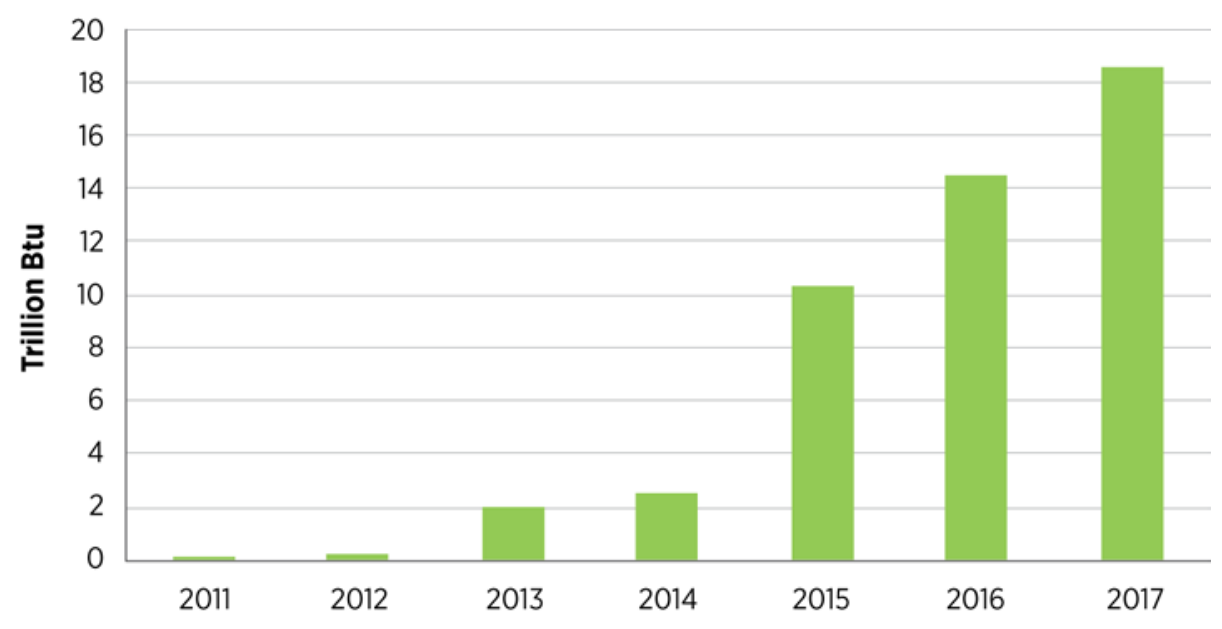

Figure 29. U.S. historical renewable gas production for transportation under the RFS

Source: EPA 2018a

A literature review conducted by the National Petroleum Council estimates that the cost for RNG production via $\mathrm{AD}$ is between $\$ 5$ and $\$ 13+$ per million British thermal units (Btu) or between $\$ 0.60$ and $\$ 1.60$ per gge (NPC 2012; Jaffe et al. 2016). The cost for producing RNG via thermochemical conversion (e.g., gasification) is estimated between $\$ 8$ and $\$ 25+$ per million Btu, or between $\$ 1.00$ and $\$ 3.10$ per gge. The study notes that the production cost depends on 
many factors, including facility size, biomass availability and cost, conversion processes, conversion yield, capital costs, delivery costs, distribution infrastructure, and others.

RNG systems offer many socioeconomic benefits, including generating revenue streams and boosting the local economy. Along with generating revenues from the sale of renewable energy products, outputs from biogas systems can offer avoided costs of on-site electricity, heat, and transportation fuel (USDA, EPA, and DOE 2014). 


\section{Biopower}

Biomass power, or biopower, is the use of biomass resources to generate electricity. There are five major types of biopower-generation technologies: combustion, co-firing, gasification, $\mathrm{AD}$, and pyrolysis. Combustion is used by most biopower plants today - bioenergy feedstock is burned directly to produce steam that turns an electricity-generating turbine (IRENA 2012). The steam could also be used for industrial processes or to heat buildings in combined heat and power (CHP) facilities. Co-firing power plants substitute solid biomass for a portion of the other primary fuel in use. In gasification systems, solid biomass is heated in a restricted supply of air to produce an energy-rich gas that can fuel steam generators, combustion turbines, combinedcycle technologies, or fuel cells. AD is a biological process in which microorganisms break down biodegradable material in the absence of oxygen. One of the end products of $\mathrm{AD}$ is biogas, composed primarily of methane, carbon dioxide, and other trace compounds. The methane is usually burned in a boiler to produce steam for electricity generation or for industrial processes, but it could also power microturbines and gas engines and feed fuel cells. Pyrolysis involves the chemical decomposition of organic materials at elevated temperatures in the absence of oxygen to produce liquid, gas, and char. The resulting pyrolysis oil can be used in traditional power generation and heating applications with minor modifications.

There are also modular bioenergy systems, which are biomass energy systems (e.g., CHP, AD, and gasification) at small scale used in off-grid, distributed-generation applications. Combustion, $\mathrm{CHP}, \mathrm{AD}$, and low-percentage co-firing are mature, commercially available technologies, whereas commercial gasification and pyrolysis are in earlier stages of development, demonstration, and deployment.

Biomass electricity generation accounts for $10 \%$ of all utility-scale renewable energy generated in the United States and about 1.6\% of total U.S. electricity generation (EIA 2018i). While the installed biopower capacity has been increasing over the past 10 years, biopower generation has remained almost flat during that period (Figure 30). The total number of biopower plants increased from 485 in 2003 to 750 in 2017 (EIA 2018j). In 2017, the top five states with the largest biopower generation were California, Florida, Georgia, Virginia, and Maine (EIA 2018i). California has adopted many policies and initiatives to promote bioenergy (e.g., California's Renewables Portfolio Standard, California Integrated Waste Management Act of 1989, Assembly Bill 341, and CalRecycle's Anaerobic Digestion Initiative), which have resulted in the largest and most diverse biomass energy industry in the country. Florida has a large biomass resource base and, through industry-driven initiatives, has also become a major biopower producer (Stuart and El-Halwagi 2012).

According to Chum et al. (2011), biopower GHG emissions can potentially be reduced (on average) by about $95 \%$ relative to coal on a well-to-plant basis. The study also finds that potential GHG emission reductions are higher for forestry and crop residues and lower for energy crops. 


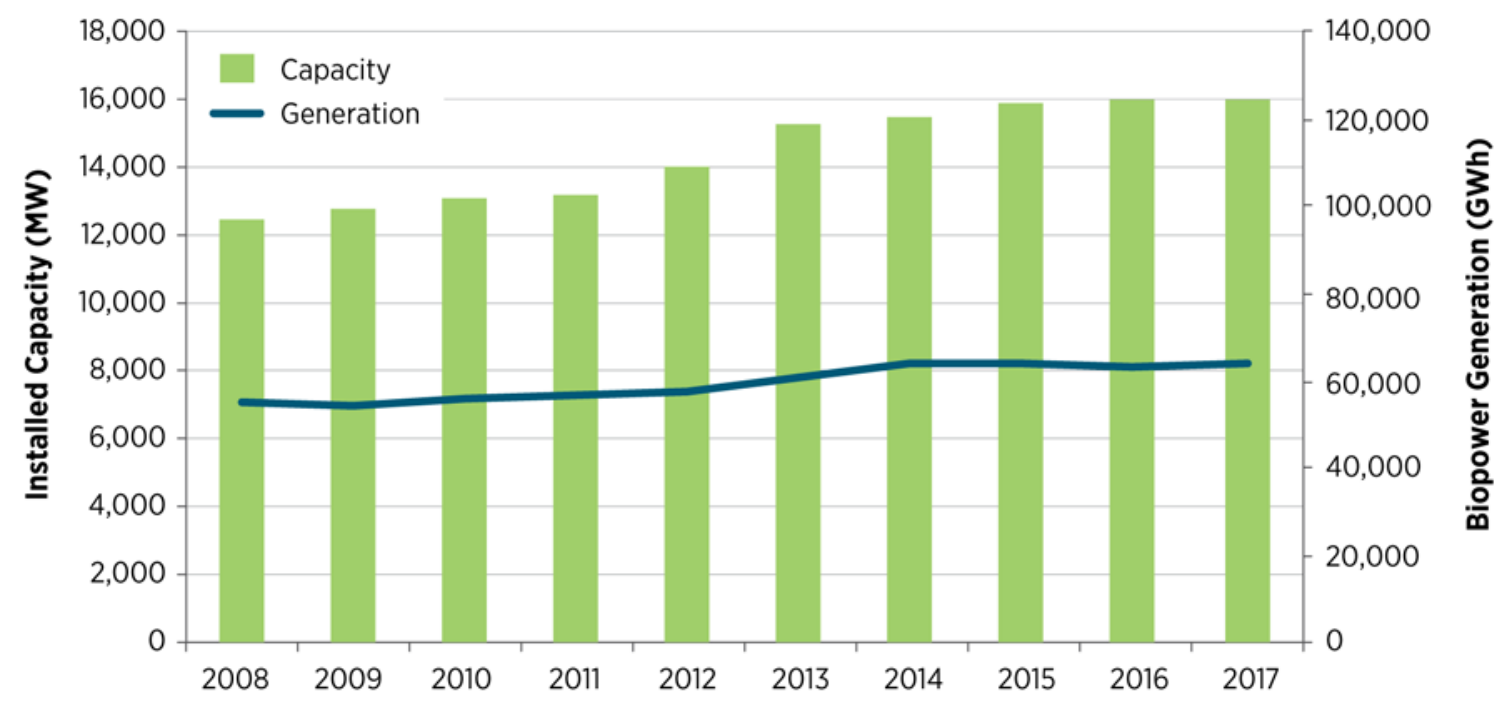

Figure 30. U.S. biopower capacity and generation

Acronyms: $\mathrm{GWh}$ = gigawatt-hour; $\mathrm{MW}=$ megawatt.

Sources: EIA 2018k; EIA 2018j. Note: Installed capacity includes both biogenic and nonbiogenic MSW due to lack of separate data. Biopower generation does not utilize nonbiogenic MSW, only biogenic MSW.

Biomass electricity is produced from various resources. These include cellulosic material (e.g., woody and crop materials, such as crop residues), biogas produced from landfills, wastewater, manure, and other organic wastes. Today, most U.S. biopower is generated from woody biomass - including byproducts (e.g., black liquor) and solids, such as low-quality wood (e.g., railroad ties and utility poles) and residues - in dedicated or cogeneration plants, such as pulp and paper mills or sawmills (EIA 2018c). Biogas is used to generate electricity for on-site use or sale to the grid and as a pipeline-quality gas (see Section 2.5 ). Solid wood and wood waste provided about $34 \%$ of total biomass power generation in 2017, black liquor provided $32 \%$, and the organic portion of MSW provided 11\% (Figure 31) (EIA 2018c). According to EIA, while the use of these resources in biomass power applications has leveled over the past 10 years, the use of landfill gas (LFG) has been increasing - from 13\% of total biopower generation in 2008 to about $18 \%$ in 2017. The use of other biomass sources - such as agricultural crop residues, sludge waste, other biomass solids, and gases-remains small in comparison. 


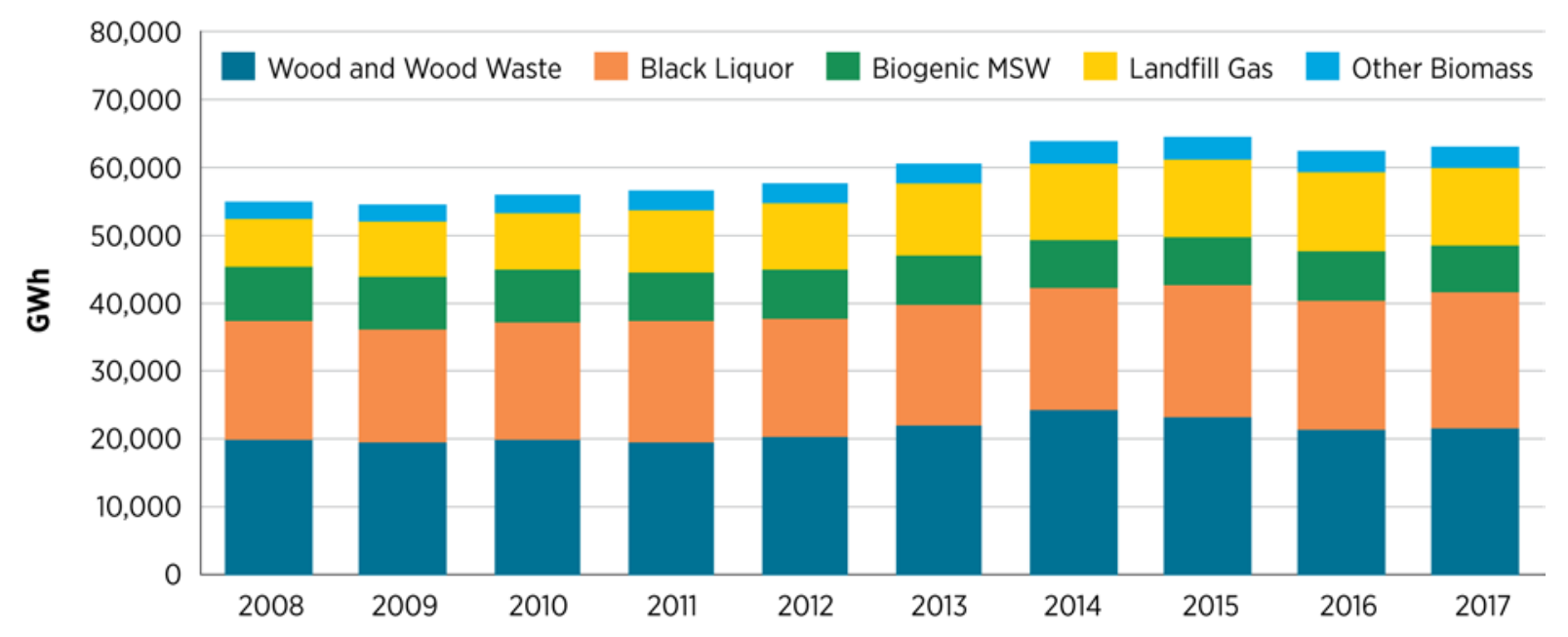

Figure 31. U.S. biopower generation sources

Acronym: GWh = gigawatt-hour

Source: EIA 2018c. Other biomass includes other biomass solids, other biomass gases, agricultural crop residues, sludge waste, wood-waste liquids, and other biomass liquids.

Because of widely varying feedstock and conversion processes, there is a large range for the levelized cost of electricity (LCOE) of biomass power generation. LCOE is a calculation of the cost of electricity produced by a generator and includes capital costs, operations and maintenance, performance, and fuel costs (feedstock). The LCOE of biomass-fired power plants globally ranges from $\$ 0.04$ to $\$ 0.29 /$ kilowatt-hour $(\mathrm{kWh}$ ) (IRENA 2012). Direct combustion is reported to have an LCOE of $\$ 0.06-\$ 0.21 / \mathrm{kWh}$; co-firing LCOE is between $\$ 0.04$ and $\$ 0.13 / \mathrm{kWh}$; LFG has an LCOE in the range of $\$ 0.09-\$ 0.12 / \mathrm{kWh}$; and the LCOE for digesters is between $\$ 0.06$ and $\$ 0.15 / \mathrm{kWh}$. The LCOE for CHP plants has an even wider range, for example, between $\$ 0.07$ and $\$ 0.29 / \mathrm{kWh}$ for stoker-fired CHP facilities. Feedstock costs typically account for between $20 \%$ and $50 \%$ of the LCOE for power-generation-only options, except co-firing (IRENA 2012). The wide range in feedstock costs is primarily due to transportation distances. For example, the feedstock cost can be zero for otherwise unusable byproduct materials that are produced on-site as a part of the industrial process (e.g., black liquor at pulp and paper mills or bagasse at sugar mills), and the use of these materials for energy avoids transport costs related to disposal; feedstock costs can be modest where agricultural crop residues can be collected and transported over short distances, and they can be high where significant transport distances are involved due to the low energy density of biomass (e.g., the trade in wood chips and pellets) (IRENA 2012). Operations and maintenance costs are typically between $9 \%$ and $20 \%$ of the LCOE for biomass power plants. They can be lower than that in the case of co-firing and greater for plants with extensive fuel preparation, handling, and conversion needs (IRENA 2012).

The biomass power industry provides many socioeconomic benefits, including gross job creation:

- It is estimated that a 50-MW dedicated biomass power plant utilizing direct combustion and using corn stover as feedstock can support about 25 direct, on-site jobs during its operation (NREL 2014). 
- A typical 3-MW LFG electricity project can directly create 5 jobs and create another 20 to 26 jobs during the construction year (Pierson 2013). It also is expected to add more than $\$ 1.5$ million in new project expenditures and increase the statewide economic output by $\$ 4.1$ million. 


\section{Bioproducts and Coproducts}

Conventional bioproducts and emerging bioproducts are two broad categories used to classify products produced from biomass feedstock. Examples of conventional bioproducts include building materials, pulp and paper, and forest products. Examples of emerging bioproducts include bioadhesives, biopolymers, and biochemicals. Emerging bioproducts are active subjects of research and development, and these development efforts have been driven by the price of traditional petroleum-based products, the environmental impact of petroleum use, and an interest in decreasing U.S. dependence on foreign oil. Bioproducts derived from bioresources can replace (either directly or indirectly) some of the fuels, chemicals, and plastics that are currently derived from petroleum.

If the bioproducts industry develops structurally like the existing petrochemical industry, it will utilize a platform-chemical approach to manufacturing. In the platform-chemical approach, a small number of chemical intermediates are produced, and these intermediates are subsequently converted to a larger number of chemical products (Corma, Iborra, and Velty 2007).

Manufacturing would operate along a supply chain from lower-value/higher-volume biomass feedstocks to lower-volume/higher-value categories like polymers, specialty chemicals, and pharmaceutically active ingredients. Based on technical evaluations and inputs from industrial experts, DOE has previously compiled a list of platform chemicals that are particularly promising as biologically derived platform chemicals (Werpy and Peterson 2004). Subsequent studies have provided additional information and updates to this earlier study (Nikolau et al. 2008; Bomgardner 2014; Biddy, Scarlata, and Kinchin 2016). The most recent study reviewed a broad range of chemicals that can be produced from biomass, yielding a subset of 12 chemicals with prospects for near-term deployment. This study provided a detailed discussion of the existing markets and future potential for each of the selected bioproducts (Biddy, Scarlata, and Kinchin 2016). Thus, there is precedent to indicate that platform chemicals derived from biomass feedstock provide a promising approach for the development of a commercial bioproducts market.

Production of bioproducts can (1) enable the production of bioenergy feedstocks as coproducts to improve the economics of the primary fuel product in an integrated biorefinery (Biddy et al. 2016) or (2) enable industrial learning to develop technologies and processes essential to the long-term production of biofuels and bioenergy. Within this context, this report considers four types of emerging bioproducts: platform and intermediate chemicals, lignin, biochar, and wood pellets.

\subsection{Platform and Intermediate Chemicals}

The biochemicals market is an emerging and immature market. A nationally accepted system for certifying and tracking production volumes (similar to RINs for biofuels) and competitive market pricing for many biochemicals do not yet exist. Many biochemical manufacturers currently treat their production and pricing information as confidential as they pursue competitive advantages within this emerging market sector. Publicly available biochemical production and pricing information is limited.

Examples of manufacturers producing platform and intermediate chemicals include DuPont Tate and Lyle's 1,3-propanediol facility in Tennessee, NatureWorks' polylactic acid facility in 
Nebraska, and the Myriant succinic acid facility in Louisiana (DOE 2015b). Commercial production of biochemicals is developing to seek out cost advantages (relative to traditional petrochemical production routes), GHG-emission reductions, and U.S. independence from foreign oil. Additionally, these facilities are stimulating the biomass feedstock supply chain for future producers of biofuels and bioproducts.

A 2018 study by Market Research Future estimated the 2017 U.S. bio-based polymer market at approximately 156,000 tons with a value of \$199.6 million (Market Research Future 2018). The primary polymers investigated were for bioplastics, and the platform chemicals of interest were glucaric acid, aspartic acid, 3-hydroxypropionic acid, and succinic acid. The U.S. market for solvents inclusive of platform chemicals of succinic acid, ethyl lactate, levulinic acid, butanol, and glucaric acid was nearly 64,000 tons, valued at \$86.8 million (Market Research Future 2018).

The 2015 USDA BioPreferred Report provides an analysis of specific bio-based segments within the U.S. economy (Golden et al. 2015). The report evaluates agriculture and forestry, biorefining, bio-based chemicals, enzymes, bioplastic bottles and packaging, forest products, and textiles as the seven major bio-based product industries contributing to the U.S. economy. It specifically excludes contributions to the economy from energy, livestock, food, feed, and pharmaceuticals. Within this stated context, the 2015 USDA BioPreferred Report estimates that direct sales of biobased products in 2013 totaled nearly $\$ 126$ billion.

Another study has estimated the current domestic market for biochemicals. Specifically within the context of this study, biochemicals include renewable commodity chemicals, renewable polymers, and other materials produced from biomass that are not consumed as fuels (Nexant 2014). It is important to note that these biochemical production estimates exclude the traditional agriculturally based oleochemicals market and thus use a much different basis than the 2015 USDA BioPreferred Report. This study indicates a consumption of approximately 3 million dry tons of biomass feedstock to produce 1.1 billion pounds ( 0.5 million tons $)$ of biochemicals per year, resulting in approximately $\$ 2.5$ billion per year in sales revenue (Nexant 2014).

Target markets for biochemicals could include the \$275-billion U.S. petrochemical industry (Nexant 2014), or the \$164-billion U.S. organic chemical manufacturing industry (IBISWorld 2017 ). Given these market valuations, biochemical sales revenues of $\$ 2.5$ billion represent a $1 \%-$ $2 \%$ share of these markets. If biochemicals are able to successfully compete with and displace existing traditional chemical production, these figures indicate the potential for increasing market penetration.

A major distinguishing market factor between biofuels and biochemicals is policy support. While production of biofuels has been stimulated and supported by policy, analogous federal policy 
support for biochemicals has not existed through the end of 2017. Iowa and Minnesota enacted bioproduct production tax credits in $2016 .^{40}$

\subsection{Lignin}

Lignin is a component of woody biomass cell walls that gives wood its distinctive structure. A total resource availability of 300 billion metric tons of lignin exists in the biosphere, making it one of the most abundant natural polymers on earth (Gregorová, Košíková, and Moravčík 2006). Assuming a lignin energy content of 25 kilojoules per gram, this renewable resource is equivalent to nearly 8,000 quads of energy worldwide. (A quad is a unit of energy equal to 1.055 $\times 10^{8}$ joules.) Of course, only some fraction of this theoretically maximum-available lignin can be captured for use in bioenergy or bioproduct applications without negatively affecting the environment and traditional markets (DOE 2015b).

The use of cellulosic feedstock to produce biofuels is on the rise; however, the industry's focus is primarily on the sugars in this feedstock (i.e., the cellulosic and hemicellulose fractions), leaving a lignin byproduct stream. Currently, lignin is considered a byproduct that is typically burned for heat and power. However, lignin is a complex class of chemicals containing aromatic rings and heteroatom functional groups that could be upgraded and valorized.

Typically, lignin will comprise $15 \%-30 \%$ of the biomass feedstock stream in a lignocellulosic biorefinery (Linger et al. 2014). The ability to convert lignin into higher-value bioproducts (compared to current heat and power utilizations) could improve profit margins for lignocellulosic biorefineries. Other smaller-volume applications of lignin include lignosulfonates used as additives and binders, agricultural dispersants, lignin-derived expanded polyurethane foam, and lignin-derived activated carbon (DOE 2015b). Lignin valorization to higher-value bioproducts is currently a topic of active research and development (Linger et al. 2014; Ragauskas et al. 2014). Potential higher-value markets for this product include transportation fuels and fuel additives, carbon fiber, and plastic materials.

\subsection{Biochar}

Biochar is a solid material obtained from the thermochemical conversion of biomass in an oxygen-limited environment. Biochar, in the form of a charcoal, can be used as a soil amendment and thus represents an avenue for GHG mitigation by contributing to carbon sequestration when applied to soils (Hofstrand 2010). Because pyrolysis is one of the conversion pathways used to produce biofuels, biochar can be produced as a coproduct with biofuels produced via pyrolysis. ${ }^{41}$ While the process for producing biochar is similar to that used for producing fossil-based charcoal, the primary use of charcoal is as a fuel for the production of heat, thus differentiating charcoal as a product from biochar based on application (IBI 2018).

\footnotetext{
${ }^{40}$ For more information on the Iowa Renewable Chemicals Production Tax Credit, visit https://www.iowaeconomicdevelopment.com/RenewableChem; for more information on the Minnesota Renewable Chemical Production Incentive Program, visit https:/www.mda.state.mn.us/environment-sustainability/renewablechemical-production-incentive-program.

${ }^{41}$ Pyrolysis oil is sold in the northeastern United States as renewable heating oil, which could enable the production of biochar as a coproduct for sale as a bioproduct: http:/www.energy.gov/sites/prod/files/2015/04/f22/demonstration_market transformation_butcher_5301.pdf.
} 
Diversity in biomass feedstock materials, production technologies, and biochar end uses (including soil conditioners, building materials, water treatment, and industrial applications) creates a complex set of parameters whose interactions and synergies are still being investigated (Schmidt and Wilson 2014). Although purposely adding biochar to soils is an established practice in some parts of the world, biochar as a commercial product is an emerging conceptboth in terms of research and of a formal biochar industry focused on promoting its adoption as a mainstream soil fertility management practice (IBI 2015).

\subsection{Wood Pellets}

Wood pellets are generally made from compacted sawdust or other residue streams of the wood harvesting and processing industries, including, for example, the milling of lumber or manufacture of wood products (WFI 2010). Chipping, shredding, and milling are typical first process steps to create a uniform, dough-like material that is fed through a press containing holes of a uniform size. The pressure of the press causes the temperature of the wood to increase greatly, causing the wood's natural lignin to plasticize slightly, forming a natural binder that holds the pellet together as it cools (Manomet Center for Conservation Sciences 2010). The main advantages of pelletizing are the creation of consistent physical and chemical characteristics, including an improvement of the feedstock's homogeneity, quality, flowability, bulk, and energy density (Tumuluru et al. 2011).

As of December 2017, there were 87 wood pellet plants in the United States with a total annual capacity of 11.8 million tons employing 2,071 people (EIA 2018i). ${ }^{42}$ In 2017, nearly 12.7 million tons of feedstock were used to produce approximately 7.1 million tons of wood pellets (EIA 2018i). Woody feedstock prices ranged between $\$ 29$ and $\$ 34$ per ton, and feedstock types used to produce wood pellets include other residuals (51\%), roundwood/pulpwood (20\%), sawmill residuals (14.7\%), and wood product manufacturing residuals (14.5\%) (Figure 32) (EIA 2018i). Production is concentrated in the South $(\sim 73 \%)$ due to the availability of feedstocks and proximity for export to European Union nations (EIA 2018i). Approximately 25\% of production was consumed domestically, largely in residential heaters (EIA 2018i).

The international trade of wood pellets as a renewable energy source has increased significantly since 2008, and the United States has established itself as the leading producer of wood pellets for export (ITA 2016). The key market driver for exports is bioenergy policies across northwestern Europe. While a steady quantity is still consumed within the United States, the main production capacity increases over the past years were mainly to fulfill the export market demand (Figure 33). In 2017, nearly 74\% of U.S. wood pellet production was exported, with $99 \%$ going to European Union nations (EIA 2018i; ITA 2016). The average export price was $\$ 138.31$ per ton (EIA 2018i).

\footnotetext{
42 EIA data do not include small facilities in monthly reporting. Biomass Magazine reports in August 2018 there were 136 pellet plants with capacity of 14 million metric tons per year. Information was accessed in September 2018: http://biomassmagazine.com/plants/listplants/pellet/US/.
} 


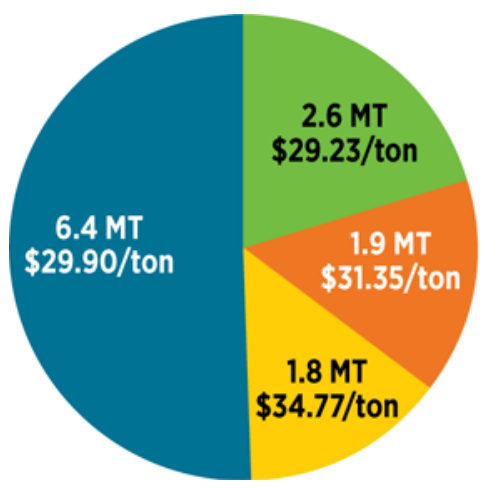

Roundwood/Pulpwood

- Sawmill Residues

Wood Product Residues

Other Residues

Figure 32. U.S. production (in million tons [MT]) and export value (\$/ton) of wood pellets in 2017 Source: EIA 2018i

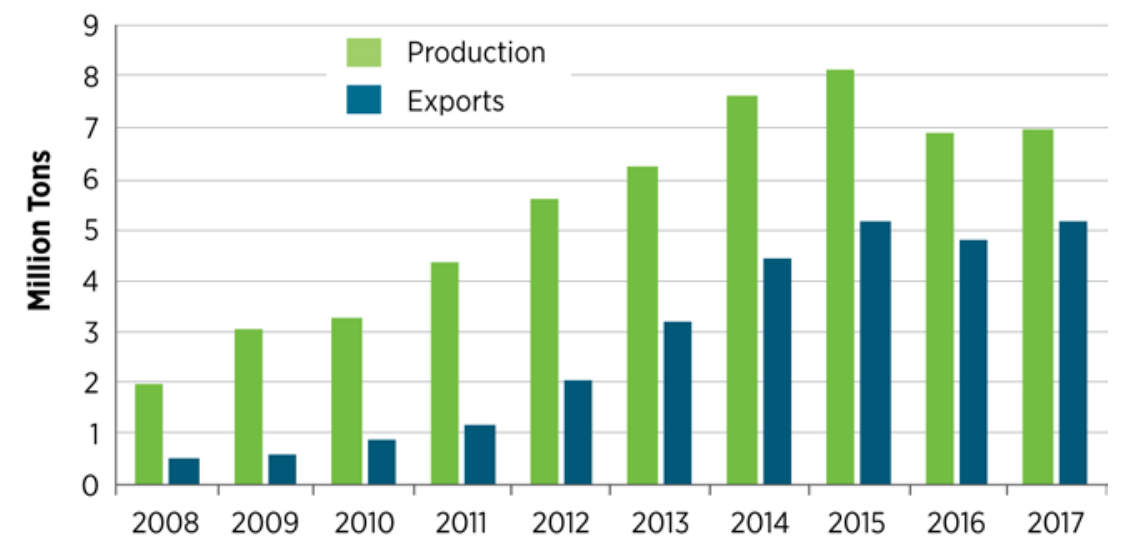

Figure 33. U.S. annual production and export of wood pellets

Sources: Thran, Peetz, and Schaubach 2017; EIA 2018i 


\section{References}

AFDC (Alternative Fuels Data Center). 2018a. "Renewable Hydrocarbon Biofuels." Accessed August 2018. http://www.afdc.energy.gov/fuels/emerging_hydrocarbon.html.

_. 2018b. “Alternative Fueling Station Locator." Last updated June 2018.

http://www.afdc.energy.gov/locator/stations.

—. 2018c. "U.S. Alternative Fueling Stations by Fuel Type." Last updated September 2018. http://www.afdc.energy.gov/data/10332.

_. 2018d. "Federal Laws and Incentives." Accessed October 2018.

https://www.afdc.energy.gov/laws/fed_summary.

Ag Marketing Resource Center. 2018. "Ethanol, Corn, and DDGS Prices at Production Facility by State." Accessed August 2018. http://www.agmrc.org/renewable-energy/ethanol/ethanolprices-trends-and-markets/.

American Biogas Council. 2016. “Operational Biogas Systems in the U.S.” Accessed July 2016.

Amyris. 2013. "Amyris and Total Announce Successful Demonstration Flight with Renewable Jet Fuel during Paris Air Show.” Aviation: Benefits Beyond Borders, June 20, 2013. https://aviationbenefits.org/newswire/2013/06/amyris-and-total-announce-successfuldemonstration-flight-with-renewable-jet-fuel-during-paris-air-show/.

Barrionuevo, A., and M. Maynard. 2006. "Dual-Fuel Vehicles Open Mileage Loophole for Carmakers." New York Times, August 31, 2006. http://www.nytimes.com/2006/08/31/business/31loophole.html?emc=eta1\&_r=0.

Biddy, M., C. Scarlata, and C. Kinchin. 2016. Chemicals from Biomass: A Market Assessment of Bioproducts with Near-Term Potential. NREL/TP-5100-65509. Golden, CO: National Renewable Energy Laboratory. http://www.nrel.gov/docs/fy16osti/65509.pdf.

Biddy, M., R. Davis, D. Humbird, L. Tao, N. Dowe, M. Guarnieri, J. Linger, et al. 2016. “The Techno-Economic Basis for Coproduct Manufacturing to Enable Hydrocarbon Fuel Production from Lignocellulosic Biomass." ACS Sustainable Chemistry and Engineering 4, no. 6: 31963211. http://doi.org/10.1021/acssuschemeng.6b00243.

Biodiesel Magazine. 2017. “U.S. Biodiesel Plants.” Last modified December 13, 2017. http://www.biodieselmagazine.com/plants/listplants/USA.

BioRefineries Blog. 2017. "Corn Fiber Ethanol - Examining 1.5G Technologies." BioRefineries Blog, April 26, 2017. https://biorrefineria.blogspot.com/2017/04/corn-fiber-ethanol-examining1.5g-technologies-biorefineries.html.

Bomgardner, M. 2014. "Biobased Polymers." Chemical \& Engineering News 92, no. 43: 10-14. http://cen.acs.org/articles/92/i43/Biobased-Polymers.html. 
Butamax. 2016. "Biobutanol: Biofuels Transformed.” Accessed July 2016. http://www.butamax.com/Portals/0/pdf/Butamax_SustainedValueforRefiners.pdf.

Cetane Energy. 2017. “About Us.” Accessed July 2017. http://www.cetaneenergy.com.

Chum, H., A. Faaij, J. Moreira, G. Berndes, P. Dhamija, H. Dong, B. Gabrielle, et al. 2011. "Bioenergy." In IPCC Special Report on Renewable Energy Sources and Climate Change Mitigation, edited by O. Edenhofer, R. Pichs-Madruga, Y. Sokona, K. Seyboth, P. Matschoss, S. Kadner, T. Zwickel, et al. Cambridge, United Kingdom, and New York, NY: Cambridge University Press.

Corma, A., S. Iborra, and A. Velty. 2007. "Chemical Routes for the Transformation of Biomass into Chemicals." Chemical Reviews 107, no. 6: 2411-2502. http://doi.org/10.1021/cr050989d.

Davis, R., L. Tao, E. C. D. Tan, M. J. Biddy, G. T. Beckham, C. Scarlata, J. Jacobson, et al. 2013. Process Design and Economics for the Conversion of Lignocellulosic Biomass to Hydrocarbons: Dilute-Acid and Enzymatic Deconstruction of Biomass to Sugars and Biological Conversion of Sugars to Hydrocarbons. NREL/TP-5100-60223. Golden, CO: National Renewable Energy Laboratory. http://www.nrel.gov/docs/fy14osti/60223.pdf.

Diamond Green Diesel. 2018. “Diamond Green Diesel.” Accessed July 2018. https://www.diamondgreendiesel.com.

DOE (U.S. Department of Energy). 2015a. Bioproducts to Enable Biofuels Workshop Summary Report. Washington, D.C.: DOE, Office of Energy Efficiency and Renewable Energy. https://energy.gov/eere/bioenergy/downloads/bioproducts-enable-biofuels-workshop-summaryreport.

- 2015b. Quadrennial Technology Review: An Assessment of Energy Technologies and Research Opportunities. Washington, D.C.: U.S. Department of Energy. http://energy.gov/qtr.

—. 2016a. 2016 Billion-Ton Report: Advancing Domestic Resources for a Thriving Bioeconomy. Volume 1: Economic Availability of Feedstocks. Langholtz, M., B. Stokes, and L. Eaton, leads. ORNL/TM-2016/160. Oak Ridge, TN: Oak Ridge National Laboratory. https://energy.gov/eere/bioenergy/downloads/2016-billion-ton-report-advancing-domesticresources-thriving-bioeconomy.

_.2016b. Bioenergy Technologies Office Multi-Year Program Plan: March 2016. Washington, DC: DOE. https://www.energy.gov/sites/prod/files/2016/07/f33/mypp_march2016.pdf.

- 2018. Clean Cities Alternative Fuel Price Report (quarterly 2008-2017). Washington, D.C.: DOE, Office of Energy Efficiency and Renewable Energy. http://www.afdc.energy.gov/fuels/prices.html. 
Dutta, A., M. Talmadge, J. Hensley, M. Worley, D. Dudgeon. D. Barton, P. Groenendijk, et al. 2011. Process Design and Economics for Conversion of Lignocellulosic Biomass to Ethanol: Thermochemical Pathway by Indirect Gasification and Mixed Alcohol Synthesis. NREL/TP5100-51400. Golden, CO: National Renewable Energy Laboratory. http://www.nrel.gov/docs/fy11osti/51400.pdf.

EIA (U.S. Energy Information Administration). 2018a. “Annual Energy Review.” Accessed June 2018. http://www.eia.gov/totalenergy/data/annual/index.cfm.

- 2018b. "Table 1.1.A. Net Generation from Renewable Sources: Total (All Sectors), 2006-December 2016.” EIA Electricity Data. Accessed June 2018. https://www.eia.gov/electricity/data.php\#generation.

—. 2018c. “Form EIA-923 Detailed Data, 2015.” EIA Electricity Data. Accessed July 2018. http://www.eia.gov/electricity/data/eia923/.

2018d. “Conventional Gasoline New York Harbor.” EIA Petroleum \& Other Liquids Data. Accessed June 2018. https://www.eia.gov/dnav/pet/pet_pri_spt_s1_d.htm.

. 2018e. "U.S. Imports by Country of Origin.” EIA Petroleum \& Other Liquids Data. Accessed June 2018. https://www.eia.gov/dnav/pet/pet_move_impcus_a2 nus_epooxe_im0_mbbl a.htm.

—. 2018f. "Exports by Destination.” EIA Petroleum \& Other Liquids Data. Accessed June 2017. https://www.eia.gov/dnav/pet/pet_move_expc_a_EP00_EEX_mbbl_m.htm.

. 2018g. "Prime Supplier Sales Volumes No. 2 Distillate.” EIA Petroleum \& Other Liquids Data. Accessed June 2018. http://www.eia.gov/dnav/pet/pet_cons_prim_dcu_nus_m.htm.

- 2018h. "Monthly Biodiesel Production Report: December 2016." EIA Petroleum \& Other Liquids Data. Accessed June 2018. http://www.eia.gov/biofuels/biodiesel/production/.

—. 2018i. "Monthly Densified Biomass Fuel Report: January 2017." Accessed June 2018. https://www.eia.gov/biofuels/biomass/\#table_data.

—. 2018j. “Form EIA-860 Detailed Data, 2015.” EIA Electricity Data. Accessed July 2018. http://www.eia.doe.gov/cneaf/electricity/page/eia860.html.

—. 2018k. “Electric Power Monthly: July 2016.” Accessed October 2018. http://www.eia.gov/electricity/monthly/epm table_grapher.cfm?t=epmt_1_1_a.

EPA (U.S. Environmental Protection Agency). 2010. Renewable Fuel Standard Program (RFS2) Regulatory Impact Analysis. Washington, D.C.: U.S. Environmental Protection Agency. EPA420-R-10-006. https://nepis.epa.gov/Exe/ZyPDF.cgi/P1006DXP.PDF?Dockey=P1006DXP.PDF.

- 2012. "Regulation of Fuel and Fuel Additives; Modification to Octamix Waiver." 77 Fed. Reg., No. 115. http://www.gpo.gov/fdsys/pkg/FR-2012-06-14/pdf/2012-14569.pdf. 
_. 2017. "Final Renewable Fuel Standards for 2014, 2015 and 2016, and the BiomassBased Diesel Volume for 2017.” Accessed June 2017. https://www.epa.gov/renewable-fuelstandard-program/final-renewable-fuel-standards-2014-2015-and-2016-and-biomass-based.

_. 2018a. "Public Data for the Renewable Fuel Standard." Accessed June 2018. https://www.epa.gov/fuels-registration-reporting-and-compliance-help/public-data-renewablefuel-standard.

—. 2018b. "Renewable Fuel Standard Program.” Accessed June 2018. https://www.epa.gov/renewable-fuel-standard-program.

Gevo. 2017. "Jet Fuel.” Accessed July 2017. http://www.gevo.com/our-markets/jet-fuel/.

Golden, J., R. Handfield, J. Daystart, and E. McConnell. 2015. An Economic Impact Analysis of the U.S. Biobased Products Industry: A Report to the Congress of the United States of America. A Joint Publication of the Duke Center for Sustainability \& Commerce and the Supply Chain Resource Cooperative at the North Carolina State University. https://www.biopreferred.gov/BPResources/files/EconomicReport 612 2015.pdf.

Green Car Congress. 2018. "Fulcrum Bioenergy breaks ground on Phase 2 of Sierra Biofuels plant; $1^{\text {st }}$ garbage-to-fuels project." Green Car Congress. May 16, 2018. https://www.greencarcongress.com/2018/05/20180517-fulcrum.html.

Gregorová, A., B. Košíková, and R. Moravčík. 2006. "Stabilization Effect of Lignin in Natural Rubber." Polymer Degradation and Stability 91, no. 2: 229-233. http://dx.doi.org/10.1016/j.polymdegradstab.2005.05.009.

Growth Energy. 2018. "Fact Sheets.” Accessed January 2018. https://growthenergy.org/resources/newsroom/fact-sheets/.

Hill, Sean. 2016. “U.S. Biodiesel and Renewable Diesel Imports Increase 61\% in 2015.” Energy Information Administration. Today in Energy, April 11, 2016. http://www.eia.gov/todayinenergy/detail.php?id=25752.

Hofstrand, D. 2010. "Using Biochar Systems to Sequester Carbon.” AgMRC Renewable Energy Newsletter, January 2010. Agricultural Marketing Resource Center, Iowa State University. https://www.agmrc.org/renewable-energy/renewable-energy-climate-change-report/renewableenergy-climate-change-report/january-2010-newsletter/using-biochar-systems-to-sequestercarbon.

_. 2018a. "Corn-Ethanol Profitability Chart." Agricultural Marketing Resource Center, Iowa State University. Accessed July 2018. http://www.agmrc.org/renewable_energy/ethanol/corn-ethanol-profitability/.

_. 2018b. "Tracking Biodiesel Profitability." Iowa State University Extension and Outreach. http://www.extension.iastate.edu/agdm/energy/html/d1-15.html. 
Humbird, D., R. Davis, L. Tao, C. Kinchin, D. Hsu, A. Aden, P. Schoen, et al. 2011. Process Design and Economics for Biochemical Conversion of Lignocellulosic Biomass to Ethanol: Dilute-Acid Pretreatment and Enzymatic Hydrolysis of Corn Stover. NREL/TP-5100-47764. Golden, CO: National Renewable Energy Laboratory. http://www.nrel.gov/docs/fy11osti/47764.pdf.

IBI (International Biochar Initiative). 2015. State of the Biochar Industry 2014 Executive Summary. International Biochar Initiative. http://www.biocharinternational.org/State of industry 2014.

2018. "FAQs.” Accessed July 2018. https://biochar-international.org/faqs/.

IBISWorld. 2017. Organic Chemical Manufacturing - US Market Research Report. IBISWorld, April 2017. http://www.ibisworld.com/industry/default.aspx?indid=467.

IRENA (The International Renewable Energy Agency). 2012. Biomass for Power Generation. Renewable Energy Technologies: Cost Analysis Series. Bonn, Germany: IRENA. https://www.irena.org/DocumentDownloads/Publications/RE Technologies_Cost_AnalysisBIOMASS.pdf.

ITA (International Trade Administration). 2016. “2016 Top Markets Report Renewable Fuels Sector Snapshot.” Washington, DC: U.S. Department of Commerce, ITA. http://rade.gov/topmarkets/pdf/Renewable_Fuels_Biomass_Wood_Pellets.pdf.

Jaffe, A., R. Dominguez-Faus, N. Parker, D. Scheitrum, J. Wilcock, and M. Miller. 2016. The Feasibility of Renewable Natural Gas as a Large-Scale, Low Carbon Substitute. UCD-ITS-RR16-20. Davis, CA: University of California - Davis, Institute of Transportation Studies. https://steps.ucdavis.edu/wp-content/uploads/2017/05/2016-UCD-ITS-RR-16-20.pdf.

Kim, C., G. Schaible, and S. Daberkow. 2010. "The Relative Impacts of U.S. Bio-Fuel Policies on Fuel-Energy Markets: A Comparative Static Analysis." Journal of Agriculture and Applied Economics 42, no. 1: 121-132. http://doi.org/10.1017/S1074070800003333.

Lane, J. 2016. "Renewable Jet Fuel Competitive Cost, at Scale: The Digest's Multi-Slide Guide to AltAir." Biofuels Digest, May 19, 2016. http://www.biofuelsdigest.com/bdigest/2016/05/19/63308/.

Linger, J., D. Vardon, M. Guarnieri, E. Karp, G. Hunsinger, M. Franden, C. Johnson, et al. 2014. "Lignin Valorization through Integrated Biological Funneling and Chemical Catalysis." Proceedings of the National Academy of Sciences of the United States of America 111, no. 33: 12013-12018. http://doi.org/10.1073/pnas.1410657111.

Manomet Center for Conservation Sciences. 2010. Massachusetts Biomass Sustainability and Carbon Policy Study: Report to the Commonwealth of Massachusetts Department of Energy Resources, edited by T. Walker, P. Cardellichio, A. Colnes, J. Gunn, B. Kittler, R. Perschel, C. Recchia, et al. NCI-2010-03. Brunswick, ME: Natural Capital Initiative Report. http://www.mass.gov/eea/docs/doer/renewables/biomass/manomet-biomass-report-full-hirez.pdf. 
Market Research Future. 2018. Bio-Based Platform Chemicals Market Research Report-Global Forecast to 2023. Maharashtra, India: Market Research Future.

https://www.marketresearchfuture.com/reports/bio-based-platform-chemicals-market-6604.

NBB (National Biodiesel Board). 2016. The Economic Impact of the Biodiesel Industry on the U.S. Economy. Washington, DC: LMC International. http://biodiesel.org/docs/defaultsource/policy--federal/lmc-study-for-nbb economic-impact-of-biodiesel june-2016final.pdf?sfvrsn=2.

Neeley, T. 2016. "Kansas Cellulosic Plant Sells for \$48M." The Progressive Farmer, December 1, 2016. https://www.dtnpf.com/agriculture/web/ag/news/businessinputs/article/2016/12/01/abengoa-completes-sale-us-ethanol-2.

Nexant. 2014. Renewable Chemicals \& Materials Opportunity Assessment. White Plains, NY: Nexant and U.S. Department of Agriculture. http://www.usda.gov/oce/reports/energy/USDA_RenewChems_Jan2014.pdf.

Nikolau, B., M. Perera, L. Brachova, and B. Shanks. 2008. "Platform Biochemicals for a Biorenewable Chemical Industry.” The Plant Journal 54, no. 4: 536-545. http://doi.org/10.1111/j.1365-313X.2008.03484.x.

NORA (National Oilheat Research Alliance). 2014. "NORA Research Shows Up to 20\% Biodiesel OK for Home Heating." NORAWeb, October 7, 2014.

https://noraweb.org/2014/10/tests-show-up-to-20-biodiesel-ok-for-home-heating/.

NPC (National Petroleum Council). 2012. Renewable Natural Gas for Transportation: An Overview of the Feedstock Capacity, Economics, and GHG Emission Reduction Benefits of RNG as a Low-Carbon Fuel. Topic paper \#22. Washington, DC: NPC Future Transportation Fuels Study. https://ngvglobal.app.box.com/s/ksg78agv7uukvgsa5800that3jf4wfvm.

NREL (National Renewable Energy Laboratory). 2013. Biogas Potential in the United States. Golden, CO: National Renewable Energy Laboratory. NREL/FS-6A20-60178. http://www.nrel.gov/docs/fy14osti/60178.pdf.

- 2014. "JEDI: Jobs \& Economic Development Impact Models." https://www.nrel.gov/analysis/jedi/models.html.

Pelkmans, L., L. Govaerts, and K. Kessels. 2008. Inventory of Biofuel Policy Measures and Their Impact on the Market. Report of ELOBIO Subtasks 2.1-2.2. Petten, Netherlands: Energy Research Center of the Netherlands. https://www.elobio.eu/fileadmin/elobio/user/docs/WP2PolicyAnalysis_v20080912.pdf.

Pierson, Rachel. 2013. "Fact Sheet: Landfill Methane.” Environmental and Energy Study Institute. April 26, 2013. http://www.eesi.org/papers/view/fact-sheet-landfill-methane.

Ragauskas, A., G. Beckham, M. Biddy, R. Chandra, F. Chen, M. Davis, B. Davison, et al. 2014. "Lignin Valorization: Improving Lignin Processing in the Biorefinery." Science 344, no. 6185: 1246843-1-1246843-10. http://doi.org/10.1126/science.1246843. 
Ramey, D. 2007. "Butanol: The Other Alternative Fuel.” In Agricultural Biofuels: Technology, Sustainability and Profitability: Proceedings of the 19th Annual Conference of the National Agricultural Biotechnology Council, hosted by South Dakota State University, Brookings, SD, May 22-24, 2007, edited by Allan Eaglesham and Ralph W. F. Hardy. Ithaca, NY: National Agricultural Biotechnology Council. http://nabc.cals.cornell.edu/Publications/Reports/nabc_19/19_1_1_Welcome.pdf.

RFA (Renewable Fuels Association). 2017. Pocket Guide to Ethanol 2017. Washington, D.C.: RFA. http://www.ethanolrfa.org/wp-content/uploads/2017/02/Pocket-Guide-to-Ethanol2017.pdf.

-2018a. Ethanol Strong | 2018 Ethanol Industry Outlook. Washington, D.C.: RFA. http://www.ethanolrfa.org/resources/publications/outlook/.

- 2018b. Pocket Guide to Ethanol 2018. Washington, DC: RFA. https://ethanolrfa.org/pocket-guide/.

—. 2018c. "Ethanol Biorefinery Locations." Accessed June 2018. http://www.ethanolrfa.org/resources/biorefinery-locations/.

_. 2018d. "Ethanol Co-products." Accessed June 2018. http://www.ethanolrfa.org/resources/industry/co-products/.

—. 2018e. "Annual Fuel Ethanol Production.” Accessed June 2018. https://ethanolrfa.org/statistics/annual-ethanol-production/.

—. 2018f. "2017 U.S. Ethanol Exports and Imports Statistical Summary." Accessed September 2018. https://ethanolrfa.org/wp-content/uploads/2018/02/2017-U.S.-Ethanol-TradeStatistics-Summary_CORRECTED2.pdf.

Rushing, S. 2011. "Carbon Dioxide Applications - A Key to Ethanol Project Developments." Biofuels Digest, November 23, 2011. http://www.biofuelsdigest.com/bdigest/2011/11/23/carbondioxide-applications--a-key-to-ethanol-project-developments/.

Schmidt, H., and K. Wilson. 2014. “The 55 Uses of Biochar." The Biochar Journal, May 12, 2014. https://www.biochar-journal.org/en/ct/2.

Schwab, A., K. Moriarty, A. Milbrandt, J. Geiger, and J. Lewis. 2016. 2013 Bioenergy Market Report. DOE/GO-102016-4605. Washington, DC: U.S. Department of Energy. http://www.nrel.gov/docs/fy16osti/63468.pdf.

S.G. Preston. 2017. "Portfolio.” Accessed July 2017. https://sgpreston.com/our-portfolio.

Stuart, P., and M. El-Halwagi. 2012. Integrated Biorefineries: Design, Analysis, and Optimization. Boca Raton, FL: CRC Press. 
Syngenta. 2017. "Syngenta discusses the future of cellulosic ethanol and opportunities for dry grind ethanol producers." Accessed July 2017. http://www.syngenta-

us.com $/$ newsroom $/$ news release detail.aspx?id=203306.

Syntroluem. 2007. "Syntroleum Fischer-Tropsch Jet Fuel Used in Successful B-52 Eight Engine Flight Test." Oil and Gas Online. Accessed July 2017. https://www.oilandgasonline.com/doc/syntroleum-fischer-tropsch-jet-fuel-used-in-s-0001.

Tan, E. C. D., L. J. Snowden-Swan, M. Talmadge, A. Dutta, S. Jones, K. K. Ramasamy, M. Gray, et al. 2016. "Comparative Techno-Economic Analysis and Process Design for Indirect Liquefaction Pathways to Distillate-Range Fuels via Biomass Derived Oxygenated Intermediates Upgrading." Biofuels, Bioproducts, and Biorefining 11, no. 1: 41-66.

http://doi.org/10.1002/bbb.1710.

Tao, L., D. Schell, R. Davis, E. Tan, R. Elander, and A. Bratis. 2014. NREL 2012 Achievement of Ethanol Cost Targets: Biochemical Ethanol Fermentation via Dilute-Acid Pretreatment and Enzymatic Hydrolysis of Corn Stover. NREL/TP-5100-61563. Golden, CO: National Renewable Energy Laboratory. http://www.nrel.gov/docs/fy14osti/61563.pdf.

Tao, L., and A. Aden. 2009. "The Economics of Current and Future Biofuels." In Vitro Cellular \& Developmental Biology - Plant 45, no. 3: 199-217. https://doi.org/10.1007/s11627-009-9216$\underline{8}$.

Taxpayers for Common Sense. 2011. Big Oil, Big Corn: An In-depth Look at the Volumetric Ethanol Excise Tax Credit. Washington, DC: Taxpayers for Common Sense. http://www.taxpayer.net/images/uploads/downloads/BigOilBigCorn.pdf.

Thran, D., D. Peetz, and K. Schaubach. 2017. "Global Wood Pellet Industry and Trade Study 2017." International Energy Agency Bioenergy: Task 40. http://task40.ieabioenergy.com/wpcontent/uploads/2013/09/IEA-Wood-Pellet-Study final-july-2017.pdf.

Tumuluru, J. S., C. T. Wright, J. R. Hess, and K. L. Kenney. 2011. “A Review of Biomass Densification Systems to Develop Uniform Feedstock Commodities for Bioenergy Application." Biofuels, Bioproducts and Biorefining 5, no. 6: 683-707. https://doi.org/10.1002/bbb.324.

Urbanchuk, J. 2018. Contribution of the Ethanol Industry to the Economy of the United States in 2017. Prepared for the Renewable Fuels Association. Doylestown, PA: ABF Economics. https://ethanolrfa.org/wp-content/uploads/2018/02/RFA-2017-Ethanol-Economic-Impact01_28_17_Final.pdf.

U.S. Congress. 2007. Energy Independence and Security Act. H.R. 6., 110th Congress. https://www.gpo.gov/fdsys/pkg/CREC-2007-12-14/pdf/CREC-2007-12-14-pt1-PgS15647-2.pdf. 
USDA (U.S. Department of Agriculture). 2015. "USDA Announces \$210 Million to Be Invested in Renewable Energy Infrastructure through the Biofuel Infrastructure Partnership." News Release No. 0300.15, October 28, 2015. http://www.usda.gov/wps/portal/usda/usdahome?contentid=2015/10/0300.xml\&navid=NEWS_R ELEASE\&navtype $=$ RT\&parentnav $=$ LATEST RELEASES\&edeployment action=retrieveconte nt.

. 2018. "Quick Stats 2.0. 2012 Census.” National Agricultural Statistics Service. Accessed July 2018. http://quickstats.nass.usda.gov/?source desc=CENSUS.

USDA, EPA, and DOE (U.S. Department of Agriculture, U.S. Environmental Protection Agency, and U.S. Department of Energy). 2014. Biogas Opportunities Roadmap. Washington, DC: USDA, EPA, and DOE. http://www.usda.gov/oce/reports/energy/Biogas_Opportunities_Roadmap_8-1-14.pdf.

USDA-ERS (U.S. Department of Agriculture Economic Research Service). 2018a. "Feed Grains Database." Accessed August 2018. https://data.ers.usda.gov/FEED-GRAINS-custom-query.aspx.

- 2018b. "U.S. Bioenergy Statistics. Table 5-Corn supply, disappearance and share of total corn used for ethanol." Accessed June 2018. https://www.ers.usda.gov/data-products/usbioenergy-statistics/.

—. 2018c. “Oil Crops Yearbook.” Accessed August 2018. http://www.ers.usda.gov/dataproducts/oil-crops-yearbook.aspx\#.VAivahZ3cqs.

Voegele, E. 2016. “Gevo: Cellulosic ATJ fuels flight, isobutanol sold in Texas.” Ethanol Producer, November 14, 2016. http://ethanolproducer.com/articles/13905/gevo-cellulosic-atjfuels-flight-isobutanol-blend-sold-in-texas.

Wang, W. C., L. Tao, J. Markham, Y. Zhang, E. Tan, L. Batan, E. Warner, and M. Biddy. 2016. "Review of Biojet Fuel Conversion Technologies." NREL/TP-5100-66291. Golden, CO: National Renewable Energy Laboratory. http://www.nrel.gov/docs/fy16osti/66291.pdf.

Warner, E., A. Schwab, and D. Bacovsky. 2017. 2016 Survey of Non-Starch Ethanol and Renewable Hydrocarbon Biofuels Producers. NREL/TP-6A10-67539. Golden, CO: National Renewable Energy Laboratory. https://www.nrel.gov/docs/fy17osti/67539.pdf.

Werpy, T., and G. Peterson, eds. 2004. Top Value Added Chemicals from Biomass. Volume 1. Results of Screening for Potential Candidates from Sugars and Synthesis Gas. Washington, DC: U.S. Department of Energy, Office of Energy Efficiency and Renewable Energy. http://www.nrel.gov/docs/fy04osti/35523.pdf.

WFI (World Forest Industries). 2010. "Making Wood Pellets." http://worldforestindustries.com/forest-biofuel/wood-pellets/making-wood-pellets/.

Wyman, C. E. 2003. "Potential Synergies and Challenges in Refining Cellulosic Biomass to Fuels, Chemicals, and Power." Biotechnology Progress 19, no. 2: 254-262. https://doi.org/10.1021/bp0256541. 


\section{Appendix}

Table A-1. Renewable Fuel Standard Biofuel Categories

\begin{tabular}{|c|c|c|c|}
\hline $\begin{array}{l}\text { Renewable } \\
\text { Fuel Standard - } \\
\text { Biofuel } \\
\text { Category }\end{array}$ & $\begin{array}{l}\text { D Code } \\
\text { Category }\end{array}$ & Biofuel Category Definition & $\begin{array}{l}\text { Major Source(s) of } \\
\text { RIN Generation in } 2016 \\
\text { (see Table } A-2)\end{array}$ \\
\hline $\begin{array}{l}\text { Renewable } \\
\text { Fuel }\end{array}$ & D6 & $\begin{array}{l}\text { Transportation fuel, transportation fuel ad- } \\
\text { ditive, heating oil, or jet fuel that is produced } \\
\text { from renewable biomass }{ }^{b} \text { and that is used to } \\
\text { replace or reduce the quantity of fossil fuel } \\
\text { present in a transportation fuel and has life } \\
\text { cycle (GHG) emissions that are at least } 20 \% \\
\text { less than baseline life cycle GHG emissions } \\
\text { unless exempted (e.g., grandfathered plants) } \\
\text { pursuant to } 40 \text { Code of Federal Regulations } \\
\text { (CFR) } \$ 80.1403 \text {. }\end{array}$ & $\begin{array}{l}\text { Ethanol derived from corn } \\
\text { starch. Also defined as } \\
\text { conventional biofuel. } \\
\text { Biodiesel }^{\text {d or non-ester }} \\
\text { renewable diesel that has life } \\
\text { cycle GHG emissions that are } \\
\text { less than } 50 \% \text { lower than base- } \\
\text { line life cycle GHG emissions. }\end{array}$ \\
\hline $\begin{array}{l}\text { Advanced } \\
\text { Biofuel }\end{array}$ & D5 & $\begin{array}{l}\text { Renewable fuel, other than ethanol derived } \\
\text { from corn starch, which has life cycle GHG } \\
\text { emissions that are at least } 50 \% \text { less than } \\
\text { baseline life cycle GHG emissions. }\end{array}$ & $\begin{array}{l}\text { Ethanol derived from sugar or } \\
\text { starch (other than corn starch). }\end{array}$ \\
\hline $\begin{array}{l}\text { Biomass-Based } \\
\text { Diesel }\end{array}$ & D4 & $\begin{array}{l}\text { Renewable and advanced fuel that is defined } \\
\text { as biodiesel, non-ester renewable diesel, heat- } \\
\text { ing oil, or jet fuel and that has life cycle GHG } \\
\text { emissions that are at least } 50 \% \text { less than the } \\
\text { baseline life cycle GHG emissions. }\end{array}$ & $\begin{array}{l}\text { Biodiesel or non-ester renewable } \\
\text { diesel that has life cycle GHG } \\
\text { emissions that are at least } 50 \% \\
\text { less than baseline life cycle } \\
\text { GHG emissions. }\end{array}$ \\
\hline $\begin{array}{l}\text { Cellulosic } \\
\text { Biofuel }\end{array}$ & D3 & $\begin{array}{l}\text { Renewable and advanced fuel derived } \\
\text { from any cellulose, hemicellulose, or lignin } \\
\text { that is derived from renewable biomass and } \\
\text { that has life cycle GHG emissions that are at } \\
\text { least } 60 \% \text { less than the baseline life cycle } \\
\text { GHG emissions. }\end{array}$ & $\begin{array}{l}\text { Biogas (including landfill gas } \\
\text { and sewage waste treatment } \\
\text { gas) produced through the } \\
\text { conversion of organic matter } \\
\text { from renewable biomass. } \\
\text { Ethanol derived from cellulose, } \\
\text { hemicellulose, or lignin. }\end{array}$ \\
\hline $\begin{array}{l}\text { Cellulosic } \\
\text { Diesel }\end{array}$ & D7 & $\begin{array}{l}\text { Any renewable and advanced fuel that meets } \\
\text { both the definition of cellulosic biofuel (D3) } \\
\text { and biomass-based diesel (D4). }\end{array}$ & $\begin{array}{l}\text { Diesel or heating oil derived from } \\
\text { cellulose, hemicellulose, or lignin. }\end{array}$ \\
\hline
\end{tabular}

a $D$ codes signify the code number in the RIN indicating its biofuel category.

b See EPA's definition of feedstocks that qualify as renewable biomass (42 U.S. Code (USC) § 7545 (0)(1)(I)).

' The baseline is defined as the average life cycle GHG emissions for gasoline or diesel (whichever is being replaced by renewable fuel) sold or distributed as transportation fuel in 2005 (42 USC § 7545 (0)(1)(C)). Gasoline contained a baseline level of 98 grams of carbon dioxide equivalent per megajoule, while diesel contained a baseline level of 97 grams of carbon dioxide equivalent per megajoule (EPA 2010).

d Biodiesel is defined as a mono-alkyl ester that meets American Society for Testing and Materials D 6751-09, Standard Specification for Biodiesel Fuel Blend Stock (B100) for Middle Distillate Fuels (40 CFR § 80.1401).

' Non-ester renewable diesel is defined as a fuel that can be used in an engine designed to operate on conventional fuel, or be heating oil or jet fuel and is not a mono-alkyl ester (40 CFR § 80.1401). 


\section{Table A-2. 2017 EPA Renewable Identification Number Generation}

\begin{tabular}{|c|c|c|c|c|c|c|c|c|c|c|c|}
\hline \multirow[b]{2}{*}{ Fuel } & \multirow[b]{2}{*}{$\begin{array}{l}\text { Equivalence } \\
\text { Value (EV) }\end{array}$} & \multicolumn{2}{|c|}{ Cellulosic Biofuel (D3) } & \multicolumn{2}{|c|}{ Biomass-Based Diesel (D4) } & \multicolumn{2}{|c|}{ Advanced Biofuel (D5) } & \multicolumn{2}{|c|}{ Renewable Fuel (D6) } & \multicolumn{2}{|c|}{ Cellulosic Diesel (D7) } \\
\hline & & $\begin{array}{c}\text { RINs } \\
\text { (ethanol } \\
\text { eq.-gallons) }\end{array}$ & $\begin{array}{l}\text { Volume } \\
\text { (gallons) }\end{array}$ & $\begin{array}{c}\text { RINs } \\
\text { (ethanol } \\
\text { eq.-gallons) }\end{array}$ & $\begin{array}{l}\text { Volume } \\
\text { (gallons) }\end{array}$ & $\begin{array}{c}\text { RINs } \\
\text { (ethanol } \\
\text { eq.-gallons) }\end{array}$ & $\begin{array}{l}\text { Volume } \\
\text { (gallons) }\end{array}$ & $\begin{array}{c}\text { RINs } \\
\text { (ethanol } \\
\text { eq.-gallons) }\end{array}$ & $\begin{array}{l}\text { Volume } \\
\text { (gallons) }\end{array}$ & $\begin{array}{c}\text { RINs } \\
\text { (ethanol } \\
\text { eq.-gallons) }\end{array}$ & $\begin{array}{l}\text { Volume } \\
\text { (gallons) }\end{array}$ \\
\hline Ethanol & 1 & $10,047,034$ & $10,047,034$ & 0 & 0 & $99,392,347$ & $99,392,347$ & $14,851,872,278$ & $14,851,872,278$ & 0 & 0 \\
\hline Biodiesel & 1.5 & 0 & 0 & $3,075,277,399$ & $2,050,164,384$ & 0 & 0 & & & 0 & 0 \\
\hline Naphtha & 1.5 & 0 & 0 & 0 & 0 & $31,529,071$ & $21,019,366$ & 0 & 0 & 0 & 0 \\
\hline Heating Oil & 1.6 & 0 & 0 & 0 & 0 & $1,956,751$ & $1,222,972$ & 0 & 0 & 0 & 0 \\
\hline $\begin{array}{l}\text { Non-Ester } \\
\text { Renewable } \\
\text { Diesel }\end{array}$ & 1.7 & 0 & 0 & $770,898,438$ & $453,469,386$ & $8,750,395$ & $5,147,237$ & $244,982,236$ & $144,107,197$ & 0 & 0 \\
\hline $\begin{array}{l}\text { Cellulosic } \\
\text { Diesel }\end{array}$ & $\begin{array}{l}\text { EV application } \\
\text { required }\end{array}$ & & & & & & & & & 459 & 270 \\
\hline $\begin{array}{l}\text { Cellulosic } \\
\text { Heating Oil }\end{array}$ & $\begin{array}{l}\text { EV application } \\
\text { required }\end{array}$ & 0 & 0 & 0 & 0 & 0 & 0 & 0 & 0 & $1,743,435$ & $1,743,435$ \\
\hline $\begin{array}{l}\text { Renewable } \\
\text { Compressed } \\
\text { Natural Gas }\end{array}$ & $\mathrm{n} / \mathrm{a}$ & $157,100,756$ & $157,100,756$ & 0 & 0 & $2,018,098$ & $2,018,098$ & 0 & 0 & 0 & 0 \\
\hline $\begin{array}{l}\text { Renewable } \\
\text { Liquefied } \\
\text { Natural Gas }\end{array}$ & $n / a$ & $83,476,683$ & $83,476,683$ & 0 & 0 & 0 & 0 & 0 & 0 & 0 & 0 \\
\hline $\begin{array}{l}\text { Renewable } \\
\text { Jet Fuel }\end{array}$ & 1.6 & 0 & 0 & $2,737,627$ & $1,711,017$ & 0 & 0 & 0 & 0 & 0 & 0 \\
\hline
\end{tabular}

Source: EPA 2018a 